Dragutin Feletar

\title{
PRINOSI ZA POVIJEST SPLAVARSTVA NA DRAVI U 19. I 20. STOLJEĆU
}

Drava, kao jedna od najvećih hrvatskih rijeka, u prošlosti je za život stanovništva imala važnu ulogu. Jedna od životnih funkcija koja se odvijala na Dravi bio je promet. Upravo je Drava bila žila kucavica koja je spajala stanovništvo u cijelom porječju. Važna sastavnica te prometne funkcije bilo je šajkaštvo i splavarstvo. U članku se uvodno razrađuju uvjeti za promet na Dravi, a potom povijest splavarstva (i šajkaštva) od antičkog razdoblja do polovice 20. stoljeća. Posebna pozornost poklonjena je razvoju splavarstva (fljojsarstva) na Dravi od kraja 18. do polovice 20. stoljeća, s temeljnom razradbom toga prometa na emitivnim pristaništima u Sloveniji (od Dravograda do Dupleka) te poslovno-distributivnim pristaništima od Maribora do Đerdapa. Razrađeno je detaljno djelovanje poslovne tvrtke Ujlaki-Hirschler i sin u Donjoj Dubravi, koja je bila središte fljojsarstva na Dravi u 19. i 20. stoljeću. Dana je razradba izgradnje i značajki splavi i šajki te načina rada i života splavara.

Ključne riječi: splavarstvo; šajkaštvo; pristanište (lenta); Drava; splavarski (šajkaški) ceh; Donja Dubrava.

\section{UVOD - DRAVA VAŽNA PROMETNICA}

Gravitirajuće stanovništvo uz Dravu u prošlosti je mnogo više ovisilo o rijeci i živjelo s rijekom. Makadamske ceste u panonskom dijelu porječja Drave grade se tek od kraja 17., a željezničke veze od sredine 19. stoljeća. Zato su do tada žile kucavice prometnog povezivanja bile rijeke, pa i one manje. I uz Dravu je funkcionirala simbioza čovjekove svakodnevice i prirodnoga ritma rijeke. ${ }^{1} \mathrm{Uz}$ Dravu se ovdje rađalo, raslo, živjelo i umiralo. Rijeka je donosila mnoge „darove“: na vodenicama se mljelo žito za kruh, uz Dravu se lovila riba, žela se trstika za graditeljstvo i zaštitu, rezala vrbova šiba za pletenje košara, sjekla vrbovina i jagnjedovina za ogrjev i pokoju dasku ili letvu, tesao hrast lužnjak za kućne grede, u zamočvarenim gustišima lovila se divlja svinja, zec, tetrijeb, patka, fazan pa i poneki srndać ili jelen, iz Drave se vadio pijesak i šljunak za zidanje

Dragutin FELETAR, Hrvoje PETRIĆ i dr., Općina i župa Donja Dubrava, Meridijani, Donja Dubrava, 2014., 99. 


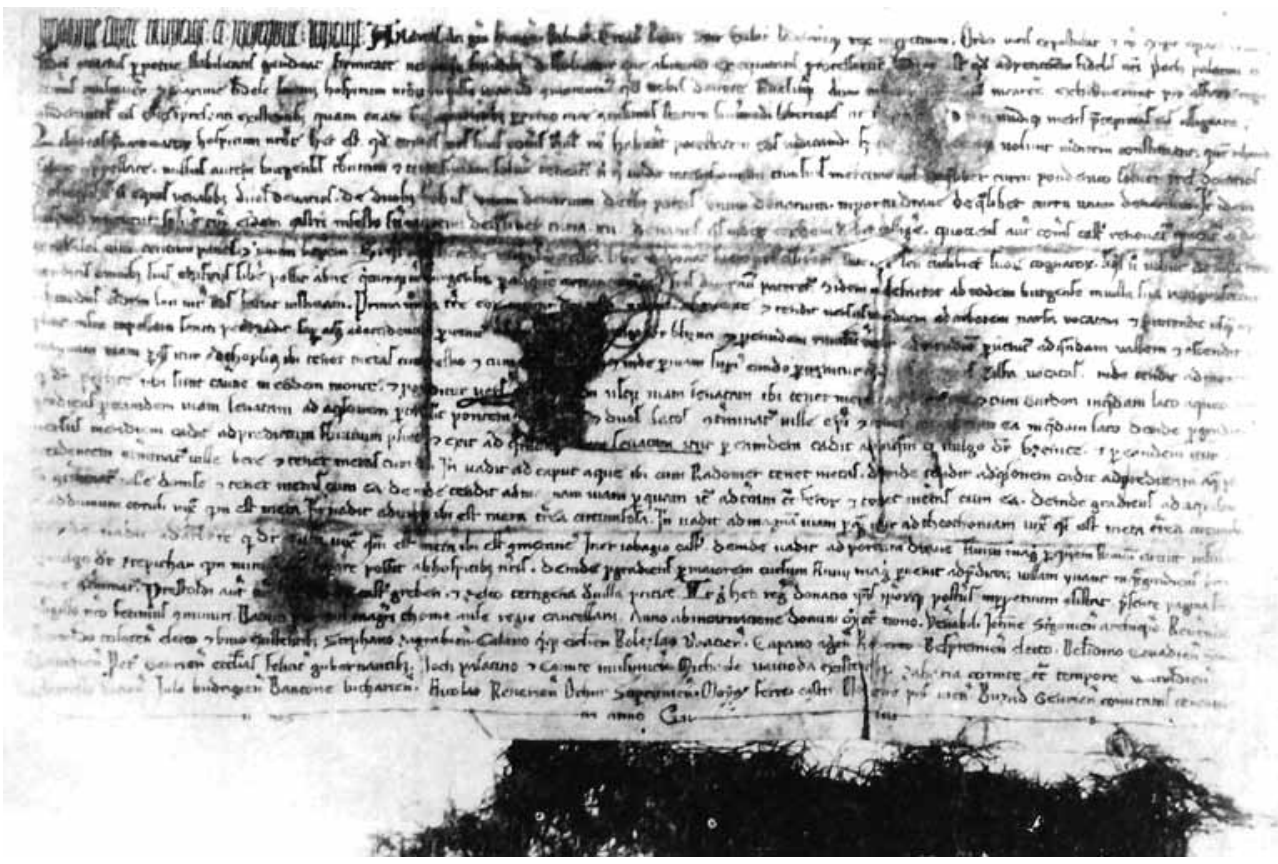

Slika 1. U ispravi Andrije II. kojom 1209. proglašava Varaždin slobodnim kraljevskim gradom spominje se i luka na Dravi (in portus Draue) (Državni arhiv Varaždin)

kuća i zavažanje putova... Preko rijeke prevozili su dravski čoni i brodi (kompi, skele), a mnoge obitelji bavile su se i s ispiranjem zlatnih „ljuskvica“ (zrnaca). ${ }^{2} \mathrm{~K}$ tomu svemu valja pribrojiti još i prometnu funkciju, jer je rijekom na šajkama i splavima (fljojsima) dolazila sva roba koja se nije mogla proizvesti na gruntu, a trgovalo se i vlastitim proizvodima, a posebice drvom (lesom). Iako je Drava dosta puta znala zamahnuti i repom riječne aždaje i dobar dio svojih darova odnijeti u poplavama i stalnim erozijama obala, ipak su rijeci priobalni stanovnici tepali „naša Drava“. Ili kako je to sublimirao Mariborčanin Matjaž Jež: „Drava je kot mati svoje pokrajine..”3

U tom kontekstu valja gledati i na značenje Drave kao prometnoga toka, koji je longitudinalno, duž cijele rijeke (i porječja) povezivao stanovništvo i bio važan faktor razvoja. Plovidbom Dravom otvarali su se i širi prometni vidici prema

\footnotetext{
2 Petar FELETAR, Istočno Međimurje, Meridijani, Samobor, 2005., 18-21; Krešimir PAVLIC, Ispiranje zlata u Međimurju, Matica hrvatska, Čakovec, 2015., 35-36.

3 Matjaž JEŽ, Drava nas povezuje, Planinarski zbornik, Varaždin, 1999., 37-41.
} 
Dunavu i njegovim pritocima. Prometna funkcija Drave posebice je bila važna u vrijeme kada nije bilo drugih mogućnosti prometovanja, a trgovina drvom nastavljena je i kasnije, sve do početka Drugoga svjetskoga rata, jer je riječna plovidba bila jeftinija od transporta drva željeznicom ili kamionima. ${ }^{4}$ Tako je Drava kroz stoljeća povezivala razmjerno veliko porječje površine $41.238 \mathrm{~km}^{2}$ (dakle nešto manje od površine Hrvatske, koja iznosi 56.603 km²), odnosno u Hrvatskoj $7.440 \mathrm{~km}^{2}$.

Drava (Dara, Darus, Dravus, Drau, Scornijunga ${ }^{5}$ ) srednjoeuropska je rijeka koja u dužini od $707 \mathrm{~km}$ povezuje gorski jugoistočni alpski prostor sa srednjim Podunavljem. ${ }^{6}$ Izvire u Južnom Tirolu (Dolomiti, Trentino-Alto Adige) u Italiji kod mjesta Tolbach (Dobbiaco), a već nakon 15 kilometara ulazi u Austriju, kroz koju teče u dužini od $243 \mathrm{~km}$. Drava kroz Sloveniju teče u dužini od $144 \mathrm{~km}$, a kroz Hrvatsku 305 km. ${ }^{7}$ Zbog razmjerno strmog uzdužnog profila korita rijeke, Drava je brzinom matice i erozijom obala "divlja“ rijeka, što je otežavalo plovidbu. I u sustavu rijeka Panonske nizine Drava slovi kao najnemirnija rijeka. Izvorišno Drava skuplja vodu s planina visokih i $3.000 \mathrm{~m}$, a njezina dva osnovna izvorišna kraka nalaze se na nadmorskoj visini od 1.228 i $1.192 \mathrm{~m}$. Drava se ulijeva u Dunav kod Aljmaša na nadmorskoj visini od $80 \mathrm{~m}$. Prema tomu, prosječan pad riječnog korita rijeke Drave iznosi $162 \mathrm{~cm}$ po dužnom kilometru, što ju svrstava među desetak najbržih srednje velikih rijeka Europe. ${ }^{8}$

$\mathrm{S}$ obzirom na geomorfološke značajke područja kroz koje teče, Drava u uzdužnom hipsometrijskom profilu pokazuje dva osnovna lica: hirovitost u gornjem toku (do Ptujskoga polja, odnosno do ušća Mure) te smirivanje u Panonskoj nizini. Od Dravograda do Donje Dubrave korito Drave hipsometrijski opada u prosjeku $155 \mathrm{~cm} / 1$ km, a od Donje Dubrave do Aljmaša samo $25 \mathrm{~cm} / 1 \mathrm{~km}$. Tim uvjetima plovidbe prilagođavala se i veličina plovila (šajki i splavi) te čvrstina njihova povezivanja. Znatne su i razlike pada profila po pojedinima dionicama

\footnotetext{
$\overline{4}$ Peter MACUH i dr., Drava nekoć in danes, Založba Obzorja, Maribor, 2000., 12-13.

5 Josip BEDEKOVIĆ, Knjiga o Sv. Jeronimu, Iliriku i Međimurju, Meridijani i dr., Zagreb - Čakovec, 2017., 547 (Original: Natale solum.., 1752.).

6 Danas se najčešće navodi dužina Drave od 707 km, ovisno o određivanju izvorišnih krakova. Vjekoslav Klaić navodi dužinu od 720 km, a u nekim današnjim izvorima navodi se i 749 km, 699 km itd. Vjekoslav KLAIĆ, Prirodni zemljopis Hrvatske, Zagreb, 1876.; Ivan OBADIĆ, Međuodnos ljudi i rijeke Drave na području Varaždinske Podravine u novom vijeku, Radovi Zavoda za znanstveni rad HAZU u Varaždinu, 18, Varaždin, 2007., 302-303. Rijeka Mura duga je 438 km, od toga kroz Hrvatsku teče u dužini od $53 \mathrm{~km}$. Pritoka Drave, Bednja, duga je $133 \mathrm{~km}$.

7 Igor ŽIBERNA, Geografski oris slovenskoga Podravja, Drava nekoč in danas, Založba Obzorja, Maribor, 2000., 46-49.

8 Hrvoje PETRIĆ, Općina i župa Drnje, Meridijani, Drnje, 2000., 29-31; Vladimir BLAŠKOVIĆ, Osobitosti Drave i njezine granice u Podravini, Podravski zbornik, 2, Koprivnica, 1976., 140-142.
} 


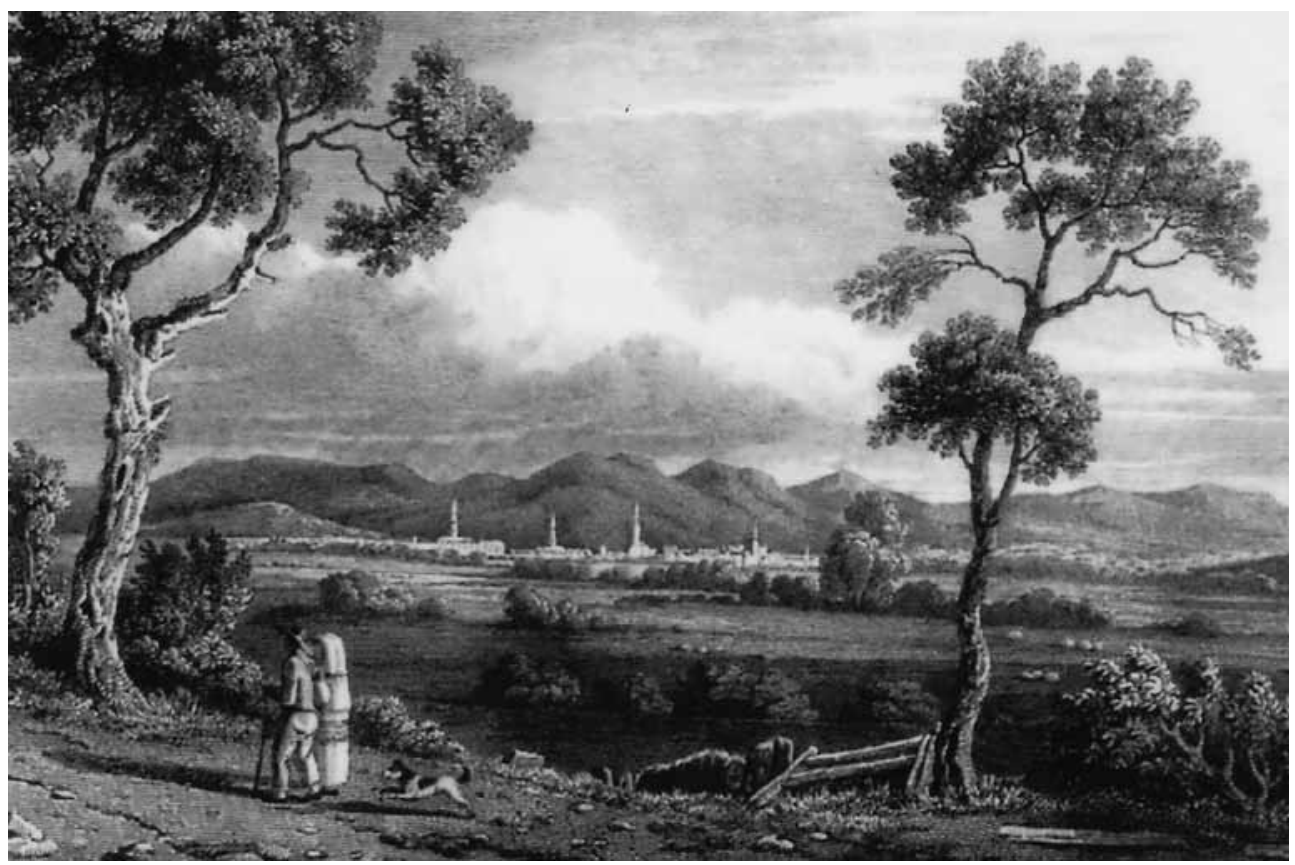

Slika 2. Pogled iz Međimurja prema Dravi i Varaždinu u doba kasnoga baroka (iz putopisa R. Brighta, 1814.)

rijeke. Tako od Villacha (Beljaka) do Dravograda prosječan pad iznosi $104 \mathrm{~cm} / 1$ $\mathrm{km}$, a potom Drava ulazi u strmi kanjonski profil između Dravograda i Maribora, gdje je prosječan pad $196 \mathrm{~cm} / 1 \mathrm{~km}$. Zato je ta ruta plovidbe bila i najrizičnija. Od Maribora do Ptuja rijeka se ponešto smiruje, te je prosječni pad $157 \mathrm{~cm} / 1$ $\mathrm{km}$, ali razmjerno brzo pada još i do Varaždina $(145 \mathrm{~cm} / 1 \mathrm{~km})$. Potom slijedi postupno smirivanje profila: između Varaždina i Donje Dubrave pad iznosi 89 $\mathrm{cm} / 1 \mathrm{~km}$, a od Donje Dubrave (ušća Mure) do Novoga Virja (ušća Ždalice) 65 $\mathrm{cm} / 1 \mathrm{~km}$. Zbog pada profila korita, Drava do ušća Ždalice još uvijek ima veliku erozivnu snagu, tako da do te točke akumulira i (sve sitnije) oblutice šljunka. Nizvodno se tok rijeke posve smiruje, te Drava postaje tipična „lijena“ nizinska rijeka: od Novoga Virja do Barča pad profila iznosi $25 \mathrm{~cm} / 1 \mathrm{~km}$, od Barča do Donjeg Miholjca $18 \mathrm{~cm} / 1 \mathrm{~km}$, od Donjeg Miholjca do Osijeka $14 \mathrm{~cm} / 1 \mathrm{~km}$ te od Osijeka do Aljmaša $18 \mathrm{~cm} / 1 \mathrm{~km} .{ }^{9}$ Nizvodno od Novoga Virja vode Drave imaju snagu samo za transportiranje čestica pijeska.

\footnotetext{
9 Topografske karte za područje nizine Drave od Dravograda do Aljmaša, 1:50.000, Geografski odsjek PMF-a, Sveučilište u Zagrebu.
} 
Za plovidbu je važna i količina (protok) vode te kretanje višegodišnjih i godišnjih mijena toga protoka. Orografske i klimatske značajke ${ }^{10}$ (pogotovo gornjeg toka) određuju režim dotoka vode u Dravu. Ovdje je riječ o nivalno-pluvijalnom režimu, što znači da vode Drave osigurava topljenje snijega i leda na Alpama, ali i režim padalina (kiša). Zato je maksimalan vodostaj Drave lociran u svibanj i lipanj, a sekundarni je maksimum tijekom listopada i studenog. Ekstremi (s poplavama, pogotovo $u$ prošlosti) događaju se u primarnom maksimumu, kada se istovremeno spoji naglo topljenje leda i snijega s obilnim kišama. Količina protoka vode $\mathrm{u}$ koritu Drave uvelike varira tijekom godine, a pogotovo kroz dulje razdoblje, što je nepovoljno djelovalo na organizaciju plovidbe. Primjerice, na mjernoj stanici Botovo izmjeren je maksimalni protok vode od čak $2.652 \mathrm{~m}^{3} /$ sek., a minimalni protok od samo $83 \mathrm{~m}^{3} / \mathrm{sek}$. Inače, prosječni ljetni protok vode u Mariboru iznosi $297 \mathrm{~m}^{3} / \mathrm{sek}$., a zimski $108 \mathrm{~m}^{3} / \mathrm{sek}^{11}$ U strojarnici HE Dubrava instalirani prosječni godišnji protok vode iznosi $500 \mathrm{~m}^{3} / \mathrm{sek}$. (s velikom akumulacijom), a godišnji prosjek protoka Drave tu je $320 \mathrm{~m}^{3} / \mathrm{sek}$. (tu su uračunate i vode Dravinje, Bednje i drugih pritoka). U limnigrafu Botovo godišnji prosjek protoka iznosi 489 - $526 \mathrm{~m}^{3} / \mathrm{sek}$. - taj veliki porast uzrokovan je novim vodama rijeke Mure. ${ }^{12}$ Prosječna temperatura vode u Dravi iznosi $9,9^{\circ} \mathrm{C}$.

Za plovidbu je od posebne važnosti dubina vode, kao i konfiguracija korita rijeke, te promjene koje se $\mathrm{u}$ toj konfiguraciji zbivaju. Od toga zavise i mikropromjene $\mathrm{u}$ kretanju matice rijeke unutar korita, odnosno njezino meandriranje i tijek erodiranja obala. Do Maribora, odnosno Ptujskog polja, Drava je izrazito erozivna rijeka koja stalno erodira obale i nosi goleme količine materijala (pogotovo do izgradnje hidroelektrana). Nizvodno je Drava pretežito akumulacijska rijeka, koja taloži šljunkovito-pjeskovite nanose, pa se korito i nešto uzdiglo u niskom pridravskom poloju, jer Drava teče u vlastitim naslagama.

Od Ptjuskoga polja do Dunava Drava teče na plioceno-kvartarnom kompleksu naslaga, odnosno u varijantama tzv. dravske depresije (potoline). Na sadašnje geološko, geomorfološko, petrografsko i pedološko stanje nizine Drave najviše su utjecale klimatske i druge (pa i recentni tektonski pokreti) promjene koje su se dogodile na prijelazu iz pleistocena u holocen, dakle prije 9 - 14 tisuća godina. To se odnosi na razdoblje zadnje oledbe ili würm, ali pogotovo na prve

10 Porječje Drave pripada najvećim dijelom Cfb-tipu klime, odnosno tipu umjerene tople kišne klime. Količina padalina u prosjeku godišnje opada od zapada prema istoku: u Dravogradu prosječno padne cca 1.210 mm, u Mariboru 1.030 mm, u Varaždinu $890 \mathrm{~mm}$ i u Osijeku 710 mm. Damir MAGAŠ, Geografija Hrvatske, Meridijani i Sveučilište u Zadru, Zagreb, 2013., 66-72.

12 Dragutin FELETAR, Regionalni park Mura-Drava, Meridijani, 155, Samobor, 2011., 22-35; Dragutin FELETAR, Energija u sustavu održivog razvoja, Meridijani, 145, Samobor, 2010., 22-34. 
Tablica 1. Dionice na Dravi od Beljaka do Aljmaša prema dužini, nadmorskim visinama i padu profila korita rijeke

\begin{tabular}{|l|c|c|c|c|}
\hline Dionica rijeke & Kilometara & $\begin{array}{c}\text { Nadmorska visina } \\
\text { početka dionice }\end{array}$ & Razlika & $\begin{array}{c}\text { Pad profila rijeke } \\
\mathrm{cm} / 1 \mathrm{~km}\end{array}$ \\
\hline Villach (Beljak) - Dravograd & 107 & 501 & 111 & 104 \\
\hline Dravograd - Maribor & 60 & 390 & 118 & 196 \\
\hline Maribor - Ptuj & 21 & 272 & 33 & 157 \\
\hline Ptuj - Varaždin & 38 & 229 & 55 & 145 \\
\hline Varaždin - Donja Dubrava & 47 & 174 & 42 & 89 \\
\hline Donja Dubrava - Novo Virje & 28 & 132 & 18 & 65 \\
\hline Novo Virje - Barč & 37 & 114 & 9 & 25 \\
\hline Barč - Donji Miholjac & 72 & 105 & 13 & 18 \\
\hline Donji Miholjac - Osijek & 50 & 92 & 7 & 14 \\
\hline Osijek Aljmaš & 17 & $85 / 80$ & 3 & 18 \\
\hline Dravograd - Donja Dubrava & 166 & 390 & 258 & 155 \\
\hline Donja Dubrava - Aljmaš & 204 & $132 / 80$ & 50 & 25 \\
\hline
\end{tabular}

Izvor: Topografske karte 1:100.000

faze holocena, kada su procesi sedimentacije, denudacije i recentne tektonike imali najveći utjecaj na formiranje geomorfološke slike terena. Tome se zadnjih stoljeća pridružuje i djelovanje čovjeka, koji također mijenja mikrotopografiju dravskoga korita i poloja. ${ }^{13}$

Prosječna dubina Drave u Hrvatskoj iznosi 2,2 m, a u kanjonskim suženjima između Dravograda i Fale i do $7 \mathrm{~m}$. To bi bilo vrlo povoljno za plovidbu splavi (pa i brodova), ali korito rijeke mikrogeomorfološki vrlo je živo i promjenljivo, pa i tijekom samo jedne godine. Paleodrava je početkom holocena s alpskoga prostora (pogotovo s nekadašnjih pleistocenih završnih morena) transportirala goleme količine rastresitog materijala (uglavnom šljunka i pijeska) u panonski dio svojega porječja. Nakon završetka topljenja pleistocene ledenjačke kape na Alpama i stabilizacijom umjerene klime, Drava je formirala današnje korito. Rijeka teče na prostranim vlastitim sedimentima, a s obzirom na to da je nastavila nositi šljunak i pijesak, njezino današnje korito ponešto se uzdiglo, tako da u donjem toku Drave ostaju nešto niži dijelovi poloja podalje od samoga korita. Zbog toga Drava neprestano stvara nove meandre, premješta sprudove (produjine) s jedne na drugu stranu korita, matica se zalijeće i dere obale, pa se mikroprofil korita stalno mijenja.

13 Dragutin FELETAR, Petar FELETAR, Prirodna osnova kao čimbenik naseljenosti gornje hrvatske Podravine, Podravina, 13, Meridijani, Koprivnica, 2008., 167-212. 


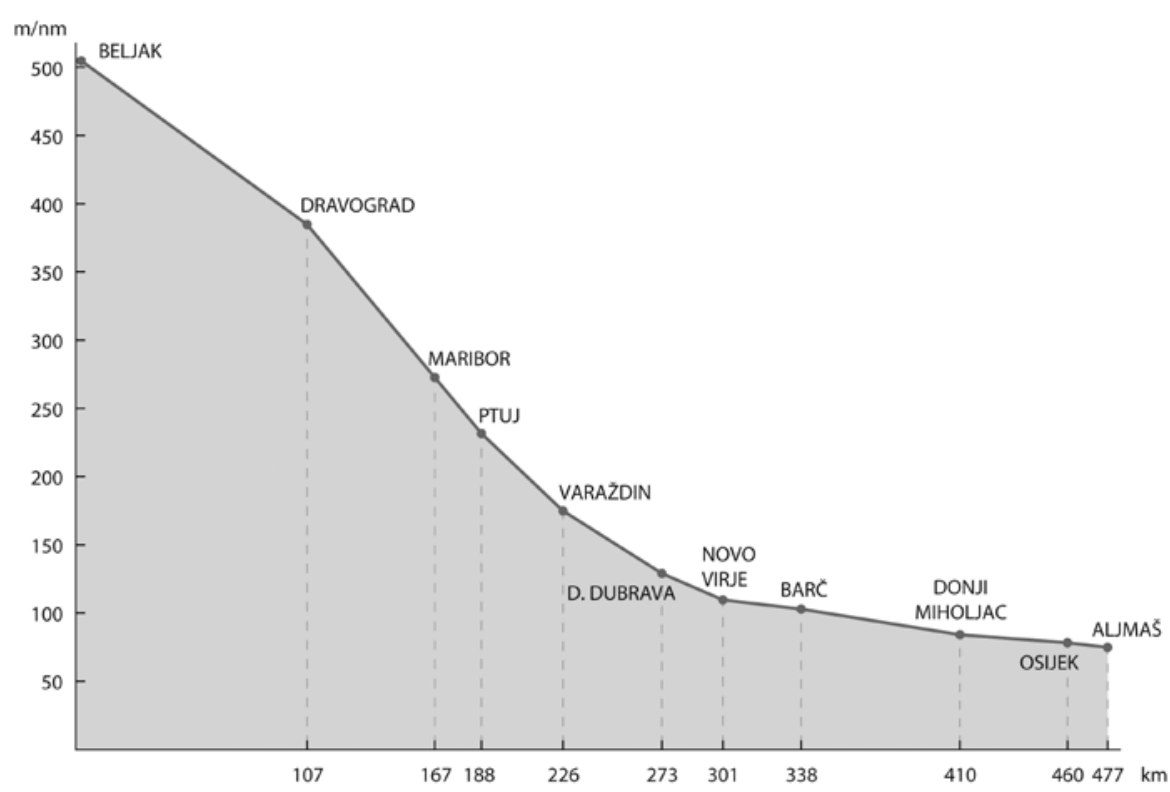

Slika 3. Uzdužni hipsometrijski profil rijeke Drave od Beljaka do Aljmaša, u nerazmjernom mjerilu (D. Feletar, 2018.)

Zato su Dravu povjesničar Vjekoslav Klaić, ihtiolog Gjuro Sebišanović i drugi još u 19. stoljeću opisali kao rijeku koju „bismo mogli nazvati i Derava, jer ona ovdje svoje obale brzim i jakim tokom dere. Kod Varaždina mijenja pravac skoro svake godine, tako da političkim oblastima puno brige i posla zadaje zbog podizanja nasipah, kojima treba da se štiti varaždinska obala. ${ }^{\text {"14 }}$ Zbog ove stalne erozivne djelatnosti matice rijeke, Drava je bila često zaleđena i više zimskih mjeseci. Stoga se plovilo uglavnom od travnja do listopada. ${ }^{15}$ Takvi uvjeti plovidbe

$\overline{14}$ Vjekoslav KLAIĆ, Prirodni zemljopis Hrvatske, Zagreb, 1876.; Gjuro SEBIŠANOVIĆ, Ihtijološke refleksije - Hidrografsko-ihtijološke ekskurzije po Županiji varaždinskoj, Varaždin, 1890.; Antica BREGOVIĆ, Prirodne značajke rijeke Drave do sredine 20. stoljeća, Život na Dravi nekad i danas, Varaždin, 2004., 60-62. Meandriranje Drave bilo je vrlo snažno, pogotovo u vrijeme velikih poplava. Tako je primjerice za poplave 1712. Drava blizu sutoka Mure prekinula vrat meandra te fizički „preselila" Legrad iz Međimurja u Podravinu, gdje se i danas nalazi. Dragutin FELETAR, Legrad, KPD Zrinski, Cakovec, 1971., 23-25.

15 O sezonskoj plovidbi splavima na Dravi govore i podaci o broju splavi koje su 1920. - 1941. prošli kroz prevodnicu na HE Fala kod Maribora. Tako je prosječno u siječnju (godišnje) prošlo 28 splavi, u veljači 43, a u ožujku 540 plovila. Taj se broj u travnju povećao na 1.473 , te se takav promet uglavnom zadržao sve do listopada (1.404 splavi), da bi u studenom opao na 1.072, te u prosincu na 244 plovila. Franjo PAHERNIK, Šajke in splavi na Dravi, Vuhred - Maribor, 1962., rukopis, 26-28. 
nalagali su posebnu tehnologiju izrade splavi (i šajki), a posada na splavi morala je biti posebno izvježbana i iskusna.

U vrijeme bečkoga merkantilizma, u 18. stoljeću, postala je jasna prednost i razvojno značenje riječnoga prometa. U našim krajevima prišlo se regulaciji najvećih rijeka ponajviše zbog poboljšanja trgovačkih veza panonskog prostora s Jadranom (pogotovo talijanskim tržištem). Nakon povlačenja Osmanlija na Savu krajem 17. stoljeća, stvarao se najfrekventniji trgovački put od Banata Dunavom, Savom i Kupom do Karlovca i potom izgradnjom povijesnih cesta (Karolina, Jozefina i Lujzijana) prema Bakru, Rijeci i Senju. ${ }^{16}$ Da bi se plovni put održavao stabilnim, rijeke su se počele uređivati i regulirati. Postojali su i vrlo ambiciozni planovi - ne samo regulacije rijeka nego i izgradnje plovnih kanala. Tako je postojao projekt povezivanja Mađarske (pa i Budimpešte) s Jadranskim morem izgradnjom plovnoga kanala - od Balatona preko Mure, Drave, Bednje, Lonje na Savu pa prema Karlovcu te Kupom do Broda i gorskim prevodnicama na Rječinu (!). ${ }^{17}$

Planovi regulacije Drave bili su znatno realniji i dobar ih je dio ostvaren, što je poboljšalo plovidbene putove i za splavarstvo i šajkaštvo. Drava je od kraja 17. stoljeća postala trgovačka žila kucavica između Kranjske i Štajerske prema južnoj Ugarskoj, Slavoniji i Banatu. Bez obzira na izgradnju makadamskih cesta, u 18. stoljeću ta je pozicija plovnoga puta Dravom još i poboljšana. Zato se regulacijom Drave i osiguravanjem plovidbe rijekom već tada bave i carske i banske službe, a ne samo lokalne vlasti i trgovačka društva. Vijesti o utvrđivanju obala kamenom nalazimo već početkom 17. stoljeća, što govori o tomu da je Dravom trgovina tekla i u vrijeme osmanske vlasti nad Slavonijom i Ugarskom. ${ }^{18}$

Krajem 18. stoljeća, u doba marijaterezijanskog merkantilizma i jozefinskih topografskih izmjera porječja Drave, od 1775. provodio se višegodišnji projekt čišćenja korita Drave, i to od Osijeka do Legrada, a prvi detaljni planovi regula-

$\overline{16}$ Karolina (Via Carolina Augusta) građena je 1726. - 1736., Jozefina (Via Josephina) 1765. - 1779., a Lujzijana (Via Ludovicea) 1803. - 1811. godine. Petar FELETAR, Hrvatske povijesne ceste - Karolina, Jozefina i Lujzijana, Meridijani, Zagreb - Samobor, 2016.

Rasprava o plovidbenom putu Balaton - Kupa - Jadran počela je još 1799. (u okviru radova na regulaciji Kupe od Karlovca prema Ozlju i Brodu na Kupi). Dapače, postojale su ambicije da se plovnim kanalom poveže porostor Panonije - od Galicije do sjevernog Jadrana! Ljudevit KRMPOTIĆ, Izvještaj o utvrđivanju granica u Hrvatskoj kraljevini od 16. do 18. stoljeća, Hannover - Karlobag - Čakovec, 1997., 372-373; Petar FELETAR, Hrvatske povijesne ceste, o.c., 61-62.

U pismu osmanskog trgovca Hagýja Memmija od 19. ožujka 1609., upućenom varaždinskom trgovcu Pergeru, u kojem se traži povećanje trgovačke razmjene. Među ostalim, Perger je u Drnje Dravom trebao dopremiti veću količinu „,kamenja kako bi Osmanlije utvrđivali nizvodno obalu Drave“. Radi se o "teškoj robi“, ipak vjerojatno oružju. Državni arhiv Varaždin (DAV), Arhiv grada Varaždina, II/958; Hrvoje PETRIĆ, Općina i župa Drnje, o.c., 75-76. 
cije rijeke postoje od 1777. godine. Ozbiljni regulacijski radovi izvode se pogotovo u prvoj polovici 19. stoljeća. Najveći dio tih radova odnosi se na utvrđivanje ugroženih dijelova obale Drave, i to u kombinaciji dovoženja kamena i zabijanjem pilona između kojih su ispletene svojevrsne ograde od vrbova pruća. Uz to na nekoliko mjesta, osobito od Varaždina do Osijeka, presijecali su se vratovi meandara iskopanim ravnijim kanalima. Drava je tako dobivala ravniji tok, pa je manje mijenjala korito i bila podobnija za plovidbu. Na radove na regulaciji Drave pozivao je i Hrvatski sabor, a sudjelovali su i brojni kmetovi s okolnih vlastelinstava. ${ }^{19} \mathrm{U}$ drugoj polovici 19 . stoljeća postojali su i konkretni planovi za regulaciju Drave kako bi se mogla uspostaviti plovidba parobrodima. Dunavsko parobrodarsko društvo u nekoliko je navrata poslalo na probnu vožnju male parobrode, a jedan od njih 1885. godine stigao je do Legrada i Donje Dubrave. ${ }^{20} \mathrm{Za}$ manje brodove Drava je osposobljena za plovidbu do Barča. Za plovidbu uzvodnije nije bilo ekonomske računice, jer bi regulacija bila gotovo nemoguća zbog hirovitosti rijeke, ${ }^{21}$ a i prijevoz većine roba preuzele su željeznice.

19 DAV, Arhiv grada Varaždina i Hrvatski državni arhiv (HDA) Zagreb, Generalkomanda za Hrvatsku i Slavoniju. Hrvoje PETRIĆ, Općina i župa Drnje, o.c., 82-84; Hrvoje PETRIĆ, Utjecaj rijeke Drave na pogranična područja, Ekonomska i ekohistorija, 1, Meridijani, Zagreb, 2005., 37-62. Dragutin FELETAR, Hrvoje PETRIĆ i dr., Općina i župa Donja Dubrava, o.c., 100-105.

Ambiciozni planovi reagulacije Drave postojali su i u drugoj polovici 19. stoljeća, a u vrijeme uvođenja parobroda u plovidbu. Pred povezivanje željeznicom Budimpešte s Pragerskim (Trstom) 1860. (preko Kotoribe), pet godina ranije (1855.) formiran je posebni odbor (konzorcij) za pregled plovnosti Drave od Legrada do ušća u Dunav te njezina povezivanja na spomenutu prugu kod Legrada i Kotoribe. Rudolf HORVAT, Poviest Koprivnice, Zagreb, 1944., 27-28. Uz angažiranje Društva južnih ugarskih željeznica, Dunavskog parobrodarskog društva, Trgovačko-obrtničke komore iz Zagreba, Hrvatsko-slavonskog gospodarskog društva, Hrvatsko-slavonsko dvorskog digasterija iz Beča, $\mathrm{Hr}$ vatskog namjesničkog vijeća u Zagrebu te pojedinih utjecajnih posjednika, trgovaca i poduzetnika (Schaumburg-Lippe iz Virovitice, Bathyany-Strattmann iz Ludbrega, Inkey iz Rasinje, Bauer iz Varaždina itd.), 1862. godine počeli su dosta opsežni radovi na regulaciji Drave, ponajprije na relaciji od Osijeka do Barča. Bericht des Handels und Gewerbkammer für Slawonien vom 2. Oktober 1860., Osijek, 1962., 14; Igor KARAMAN, Privreda i društvo Hrvatske u 19. stoljeću, Zagreb, 1986., 190-191. O važnosti regulacije Drave tada je zaključeno i sljedeće: „Godine 1862. pokrenuto je pitanje uređenja Drave, pa neki anonimni novinski izvjestitelj s pravom primjećuje: jedan od najvažnijih poslovah za našu domovinu jest uređenje Drave za plovidbu. Naša trgovina s dervima, žitom i ostalimi proizvodima nije se do sada onako razvijala, kako bi se bila mogla.. Otvori li se plovitba na Dravi i time slavonskoj tergovini kratak i lagan put do svetovnog teržišta.., nastalo bi i postepeno poboljšanje, kojebi logično izazvalo i podizanje životnih uvjeta. Uz to bi razvijenija tergovina omogućila procvat zaostale i slabe industrije." Miroslava DESPOT, Industrija građanske Hrvatske 1860.-1873., Zagreb, 1970., 30-31. Koprivničanci su bili oduševljeni tim zahvatima u prometu, u koje je u svega nekoliko godina utrošena tada velika suma od oko sto tisuća forinti, jer su se ponadali da će njihov grad „kada se u Legradu uredi parobrodarstvo biti udaljen od riječne luke svega jedan i pol sata vožnje kočijom". Rudolf HORVAT, Poviest Koprivnice, o.c., 277. Unatoč velikim poteškoćama zbog nemirnog i neuređenog riječnog korita, stalnih mijenjanja obala i dubina vode, plovidba brodova Dunavskog parobrodarskog društva započela je Dravom već ujesen 1862. godine. U desetak sljedećih godina uglavnom je regulirano ili je barem djelomice uređeno korito Drave od Osijeka do Barča. Kako je tada 


\section{PREGLED POVIJESTI SPLAVARSTVA NA DRAVI}

\subsection{Splavarstvo (i šajkaštvo) na Dravi do početka 19. stoljeća}

U pretpovijesno doba rijeke su bile gotovo jedini smjerovi komunikacije, pa tako i Drava (i pritoci). U antičko doba, dakle u prvim stoljećima nakon Krista, rimske vlasti grade prve ceste za promet konjima, ali i kolima. Središnja prometna točka na Dravi bio je Ptuj (Poetovium), a sekundarni prometni centar Osijek (Mursa) blizu limesa na Dunavu. Pretpostavlja se da je upravo u Poetoviji bilo križište znamenitog Jantarskog puta (od Baltika prema Jadranu) i longitudinalnoga puta dolinom Drave. U arheološkim izvorima u Ptuju se spominje riječna flota na Dravi (plovidba je bila moguća od Ruša nizvodno), a na jednom kamenom spomeniku navodi se i kapetan lađe (trierarcha). ${ }^{22} \mathrm{Na}$ antičkim itinerarima, pa i na Tabuli Peutingeriani, u cijeloj svojoj dužini ucrtana je i rijeka Drava (Darus). ${ }^{23}$

Plovidba Dravom spominje se već u prvim dokumentima iz kasnoga srednjega vijeka, koji postoje o sjeverozapadnoj Hrvatskoj. Ovdje ćemo spomenuti znamenitu bulu hrvatsko-ugarskoga kralja Andrije, kojom Varaždinu podaruje titulu slobodnoga kraljevskoga grada 1209. godine. U tom se dokumentu spominje i luka na Dravi (in portu Draue). ${ }^{24}$ Brojni dokumenti koji govore o naseljima uz Dravu iz 13. stoljeća spominju plovidbu Dravom, pristaništa, kao i prijevoz na šajkama i splavima. U tom kontekstu osobito su bili važni prijelazi preko rijeke, o čemu govore listine povlastica i o ubiranju prijevoznine. ${ }^{25}$

ponestalo novaca (i entuzijazma), a tu su bili i brojni drugi ekonomski i društveno-politički faktori, s regulacijom Drave do Legrada definitivno se odustalo. Pogotovo kada je 1885. Barč povezan željeznicom, te tako postao plovidbeni terminal na Dravi. Igor KARAMAN, Privreda i društvo Hrvatske.., o.c., 191-193; Dragutin FELETAR, Podravina, Muzej Grada Koprivnice, Koprivnica, 1988., 195-197.

Sašo RADOVANOVIČ, Svet ob reki Dravi, Drava Nekoč in Danes, Založba Obzorja, Maribor, 2000., 68-69; Mirela SLUKAN-ALTIĆ, Povijesna kartografija, Meridijani, Samobor, 2003., 223-224; Barbara ŠTURMPERGER, ur., Obrt na Ptujskem, OOZ, Ptuj, 2013.

Mirela SLUKAN-ALTIĆ, Kartografski izvori za rekonstrukciju i praćenje razvoja prometnih komunikacija, Ekonomska i ekohistorija, 1, Zagreb, 2005., 86-87; Petar FELETAR, Hrvatske povijesne ceste, o.c., 25-26.

U slobodnom prijevodu s latinskog, piše: „Niti jedan građanin (Varaždina) nije dužan plaćati tribut i tridesetnicu, osim kada ide svojom robom u Njemačku (in Teuthoniam), neka plati (carinu) od svakih natovarenih kola 3 denara, za svakog konja za prodaju 2 denara, za dva vola 1 denar, na pristaništu Drave (in portu Dravae) za svaka natovarena kola 1 denar“. Zapravo, pristanište (luka) na Dravi kod Varaždina se u ovom dokumentu iz 1209. spominje dva put: prvi put kada se govori o pristojbama, te drugi put kada se govori o granicama slobodnog kraljevskog grada Varaždina. Codex Diplomaticus, ur. Tadija Smičiklas, sv. III., Zagreb, 1905., dokument 75, str. 89-91.

Hrvoje PETRIĆ, Prilog poznavanju srednjovjekovnih puteva u središnjoj Hrvatskoj, Radovi, II./26, Hrvatski zavod za povijest, Zagreb, 1993., 17-26: Miha KOS, Potujoči srednji vek, Cesta, popotnik in promet na Slovenskem med antiko in 16. stoletjem, Založba ZRC, SAZU, Ljubljana, 1998., 154-155. 
Vijesti o splavarenju na gornjem i srednjem toku Drave nalazimo također iz kasnoga srednjega vijeka, odnosno podaci o splavarstvu datiraju iz istog razdoblja kao i građa o nastanku priobalnih naselja. Tako dokumenti iz 1280., kao i iz 1371./1372., spominju plovidbu između Velikovca i Maribora, ${ }^{26}$ a osobito su aktivna bila pristaništa na Dravi između šumovitih planina Pohorja i Kobanskog. Plovidba je bila živa osobito od Beljaka do Maribora i Ptuja te dalje prema Varaždinu. Kralj Matija Korvin 1468. je na molbu varaždinskog magistrata poveljom odredio da se ne smije ubirati nikakva carina od onih ljudi koji po rijeci Dravi dopremaju drvnu građu za potrebe grada Varaždina. ${ }^{27}$

Povezivanjem s trgovcima na širem srednjoeuropskom i jadranskom prostoru, od kraja 15. stoljeća trgovina drvom i merkantilnom robom na Dravi znatno je živnula. Veliko središte tih trgovačkih poslova bio je Beljak (Villach) na Dra$v{ }^{28}{ }^{2}$ Jedan od smjerova distribucije robe tekao je šajkama i splavima Dravom prema Mariboru i Ptuju te dalje nizvodno. Upravo je Ptuj od početka 16. pa do početka 18. stoljeća bio glavno središte trgovine Dravom, na kojoj je izgrađeno pristanište (s mitnicom i tridesetnicom). Ptuj, koji su 1490. zadobili Habsburgovci, trgovački se toliko razvio da su ga po toj funkciji uspoređivali s Beljakom, a pogotovo Mariborom. ${ }^{29}$ Mađarski su trgovci u ptujskom pristaništu (pristan, lent) plaćali mitnicu od 2 zlatna denara po splavi (šajki) venecijanske robe. Trgovina, pa i građevnim drvom, iz Ptuja bila je razvijena i s osmanskom okupiranom Slavonijom i pogotovo Ugarskom. ${ }^{30}$

Potkraj 15. stoljeća započele su i osmanske vojne provale prema Ptuju i Mariboru, pa su šajke i splavi Dravom vozile i vojnu opremu potrebnu za obranu. Štajerski državni staleži odlučili su 1538. izgraditi veći broj šajki i splavi kako bi se prevozilo vojni materijal četama u Hrvatskoj i južnoj Ugarskoj. Na pristaništu u Vuzenici samo su prve godine izradili 40 šajki, a posao je nastavljen sve do 1542.

26 Brezno in Podvelka, Bogata zgodovina dveh majhnih krajev, Podvelka, 2012., 4-5; Urbar samostana Sv. Pavla iz 1289. spominje da su kmetovi prevozili drvo Dravom na Štajersko. Urbar Sv. Lovrenca na Pohorju iz 1371. navodi da su se podložnici bavili prijevozom različitih vrsta drva, posebno kolcima za vinograde. Sašo RADOVANOVIČ, Svet ob reki Dravi, o.c., 83-84.

DAV, Arhiv grada Varaždina, br. 132. Rudolf HORVAT, Povijest grada Varaždina, Zavod za znanstveni rad HAZU, Varaždin, 1993., 41.

28 Trgovci iz Beljaka (i neki iz Ptuja i Varaždina) nabavljali su robu u Veneciji, Aachenu, Frankfurtu, Nűrnbergu, Kreuznachu i drugdje, te dio blaga transportirali Dravom. Sašo RADOVANOVIČ, Svet ob reki Dravi, o.c., 87-88; Maja KANOP, Drava - negdaj plovna reka, Drava nekoč in danes, Založba Obzorja, Maribor, 2000., 157-158.

Miha KOSI, Potujoči srednji vek, o.c., 155.

30 Sašo RADOVANOVIČ, Svet ob reki Dravi, o.c., 88-89; Maja KANOP, Drava - negdaj plovna reka, o.c., $157-158$. 
godine. ${ }^{31}$ Poslovi za vojsku dali su polet šajkaštvu i splavarstvu na Dravi, pa se tijekom 16. i 17. stoljeća razvio veći broj pristaništa na Dravi, pogotovo od Libeliča do Maribora. Od Vuzenice, na kanjonskom toku Drave između šumovitih gora Pohorja i Kobanskog (Kozjaka), razvila su se i pristaništa u Libeličama, podno Lovrenca, Rušama, Ribnici, Dravogradu, Vuhredu, Brezni, Selnici, Podvelki, Ožbaltu i drugdje. Promet prvenstveno drvom, ali i merkantilnom robom, dosegao je u 17. stoljeću velike razmjere, tako da su se šajkaši i splavari počeli udruživati u bratovštine i cehove. ${ }^{32}$ Kako bi trgovina Dravom tekla dvosmjerno, što pogotovo vrijedi za merkantilnu robu (koja se prevozila šajkama), postojali su planovi da se uz Dravu urede i posebne staze kako bi šajke i lađe mogli uzvodno vući konji i volovi. Dio te zamisli djelomice je ostvaren na koruškom potezu Drave od Beljaka prema Spittalu. ${ }^{33}$

Na kraju 17. stoljeća u dugom Bečkom ratu protiv Osmanlija, kada su oni konačno protjerani na Savu, potrebe vojske za prijevozom raznih roba, baruta, oružja i ratne opreme, dale su i novi polet splavarstvu na Dravi. U Ptuju i Varaždinu bilježe da se uz drvo na splavima i šajkama uglavnom prevozila roba za vojne jedinice u Slavoniji i Banatu, pogotovo od 1684. do 1687. godine. Kako se navodi, „taj je prijevoz bio velika pomoć vojsci u ratu, ali također i u razvoju slobodne trgovine“. ${ }^{34}$

Uz glavna trgovačka središta, s uređenim pristaništima i tridesetnicama na Dravi (lent, pristan), kao što su prvenstveno bili Beljak, Maribor, osobito Ptuj, te donekle Varaždin, u 17. stoljeću značenje dobivaju i manja središta na rijeci - poput Preloga, Kotoribe, Legrada i Drnja. Osmanlije su 1600. - 1680. vladali velikom Kanjižom, a granica dvaju carstava dosegla je Dravu i donji tok Mure. Međutim, trgovina sa Slavonijom, južnom Ugarskom, pa i srednjim Podunavljem nije prestala, a na osmansku granicu valjalo je stalno dopremati i robu za potrebe vojske. Uz kršćanske utvrde u Legradu, Kotoribi i Drnju uređena su na rijeci i pristaništa (portus Dravae), a u Prelogu i Drnju kasnije su (u 18. stoljeću) izgrađene i solane koje su opskrbljivale šire područje (sol se dovozila i odvozila i Dravom i Murom).

\footnotetext{
$\overline{31}$ Upravitelj gradnje šajki u Vuzenici zvao se Vid Ivniški. Godine 1538. u Vuzenici su izradili i 40 šajki za hrvatske banove u Slavoniji. Maja KANOP, Drava - negdaj plovna reka, o.c., 158.

32 Ivan VERBOTEN, Peter MACUH, Splavarstvo na Dravi in Donavi, Drava nekoč in danes, Založba Obzorja, Maribor, 2000., 197-201.

33 Već 1492. u Koruškoj, prema Spittalu, postoji uz samu Dravu prosjek izgrađene staze za „konjsko vleko ladij oziroma čolnov“. Miha KOSI, Potujoči srednji vek, o.c., 156-157.

34 Othmar PICKL, Mur und Drau als Verkehrswege nach Südosten, Mogersdorf, sv. 9, Maribor, 1977., 225-227.
} 
Na podatke o trgovini Dravom prema osmanskom području nailazimo u Drnju već u 1609. godini, a 1635. spominje se važan prijelaz preko rijeke kod ovoga mjesta. ${ }^{35} \mathrm{U}$ Legradu su trgovinu s Osmanlijama vodili Zrinski (osobito su kupovali stoku, a prodavali im sol i drugu robu te poznate legradske noževe). Hrvatski sabor odlučio je 1660. da se u Drnju uredi tridesetnica (carinarnica) za robu uvezenu iz turskih krajeva. ${ }^{36}$ Tijekom velikog Bečkog rata potkraj 17. stoljeća, odlučeno je da se u Grazu, Ptuju, Legradu, Drnju i Virovitici (koja je oslobođena 1684.), urede posebni ratni magazini na Muri i Dravi - tu se 1986./1687. nalazilo na zalihi samo 381,4 t vojničkog dvopeka. Za transport vojnog materijala građene su posebne splavi i brodice (šajke) u Legradu, a od 1. do 6. lipnja 1687. samo iz Legrada i Drnja Dravom je prema operacijskom području oko Siklosa (u južnoj Ugarskoj) krenulo 68 brodica i Djelovanje luka na sutoku Mure i Drave (od Preloga te osobito Legrada i Drnja,

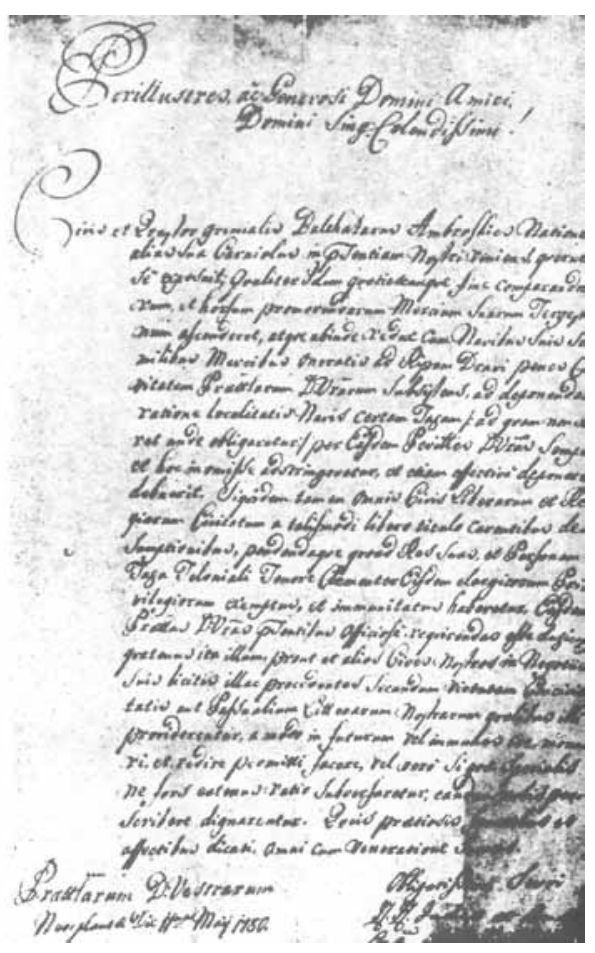

Slika 4. Osim što se luka na Dravi kod Varaždina spominje u dokumentu iz 1209., ona se navodi i u dokumentu iz 1780. godine (Državni arhiv Varaždin)

12 splavi. Takvih je transporta bilo više, a trgovalo se i nevojničkom robom. ${ }^{37}$

$\overline{35}$ Varaždinski trgovac Vincentius Perger 1609. dobiva 200 dukata za „tešku robu“ (vjerojatno oružje) od kaniškoga paše, koje je Perger dopremio do luke u Drnju, a Osmanlije su je Dravom odvezli nizvodno. Mirko ANDROIĆ, Varaždinski trgovac Vinko Perger, Kaj, 10, Zagreb, 1972., 67-68; Hrvoje PETRIĆ, Općina i župa Drnje, o.c., 76.

Iz 1681. postoji odluka Hrvatskoga sabora da se ima plaćati desetina od robe uvezene iz Turske kod Drnja. Hrvoje PETRIĆ, Općina i župa Drnje, o.c., 77.

37 Primjerice, 10. 5. 1687., uz pomoć 300 hajduka i 85 vojnika, iz Legrada i Drnja Dravom je prema istoku isplovilo 45 brodova i 23 splavi (vozili su materijal za garnizon kod Siklosa u južnoj Ugarskoj). U razdoblju 14. 8. - 13. 10. 1687. iz Drnja je Dravom isporučeno 560,8 t kruha, 117.881 obroka dvopeka, $189 \mathrm{t}$ brašna, 9.724 četvrtinke zobi, $4 \mathrm{t}$ soli itd. Jedna od zadnjih vojnih pošiljki iz Legrada i Drnja bila je izvršena 1. - 24. 11. 1687., na 96 brodica i 32 splavi - za tvrđave u Virovitici, Siklosu, Kaposvaru, Pečuhu i Osijeku. Za potrebe vojske u Legradu i Drnju izgrađeno je na desetke velikih krušnih peći. Oskar PICKL, Udio Štajerske u pobjedi nad Turcima kod brda Harsany 1687. godine, Prilog logistici Velikog turskog rata, Historijski zbornik, 41, Zagreb, 1988., 212-213; Hrvoje PETRIĆ, Općina i župa Drnje, o.c., 77-78. 
a kasnije Donje Dubrave, pa i Kotoribe) nastavljeno je i u sljedećim stoljećima, da bi u 19. stoljeću upravo Donja Dubrava postala središnje poslovno mjesto splavarstva na Dravi.

U 18. stoljeću (i pod utjecajem merkantilizma), trgovina Dravom, kako šajkama tako i osobito splavima, postala je svakodnevna i sve organiziranija djelatnost. Na Pohorju i Kozjaku (Kobanskom) i u susjednim šumovitim područjima, kmetije osnivaju sve veći broj pilana (žaga), bilo na ručni pogon ili snagu potoka (potočne žage), a na Pohorju počinju raditi i domaće staklane (glažute), što je dalo dodatni poticaj za trgovinu drvom (lesom). Iz viših predjela balvani se spuštaju na potoke i potom na glavna sabirališna pristaništa na Dravi. ${ }^{38}$ Kao glavna sabirna pristaništa (lente) na brzacima Drave između Pohorja i Kobanskog sve se više afirmiraju, po količini prometa, Meža pri Dravogradu, Vuzenica, Vuhred, Brezno, Fala, Smolnik pri Rušah, Selnica i druge. Računa se da je po Dravi prema Mariboru, Ptuju i Legradu u drugoj polovici 18. stoljeća godišnje prosječno plovilo $700-1.000$ splavi radi trgovine drvnom građom. K tome još valja pribrojiti 500-tinjak šajki s drugom, uglavnom merkantilnom robom. ${ }^{39}$

U 16. i 17. stoljeću osobitu važnost za splavarstvo u izvorišnom dijelu drvne građe imala je Vuzenica, kao sabirno pristanište, sjedište trgovaca i brojnih splavara i kao gradilište šajki i splavi. U okolnim selima razvilo se žagarstvo (pilane) ili kmečke žage (pile su nabavljali u Veneciji). Samo u Ribnici djelovalo je 17 seljačkih pilana. Pojedine kmetije uglavnom izravno prodaju drvnu građu prema Mariboru, Ptuju, pa sve do Donje Dubrave. Uz piljenu građu i balvane, Dravom se transportiraju kolci za vinograde, duge za bačve i vinogradarsko suđe, drvo za ograde i slično. Upravo u Vuzenici, kao izvorištu vrsnih splavara, javljaju se i prve splavarske udruge. Iz 1776. sačuvani su zapisnici i popisi članova bratovštine splavara, a ta je udruga (zapravo ceh) prestala postojati tek početkom Prvoga svjetskoga rata. ${ }^{40}$ Bratovština (ceh) splavara u Vuzenici imala je 1776. godine 57 majstora splavara, 27 momaka pomagača i 20 braće i sestara podupirućih članova. U ceh su bili učlanjeni splavari s cijelog područja vuzeničkog državnog suda.

38 Potoci i rječice bili su mjesto transporta balvana, pojedinačno ili povezanih u snopove. To se odnosi na praktički sve potoke u gornjem porječju Drave, ali, dakako, i drugdje u Sloveniji. Primjerice, slovenski povjesničar Žiga Zwitter opisuje takav transport na Savinji i Lučnici, gdje se tim poslom bavilo više desetaka kmetija. Osobito se trgovalo smrekom - uredi Luče i Solčeva su samo 1688. isporučili 800 - 1.100 kubika drvne građe. O transportu na rijekama opsežno je pisao i slavni kranjski polihistor J. W. Valvasor. Žiga ZWITTER, Agrarna zgodovina dve gospodstev med Podjuno in Menino v 16. in 17. stoletju, Vizija raziskav slovenske gospodarske in družbene zgodovine, ZRC, SAZU, Ljubljana, 2014.

Miha KOSI, Potujoči srednji vek, o.c., 156-157.

40

Maja KANOP, Drava - negdaj plovna reka, o.c., 157-159. 


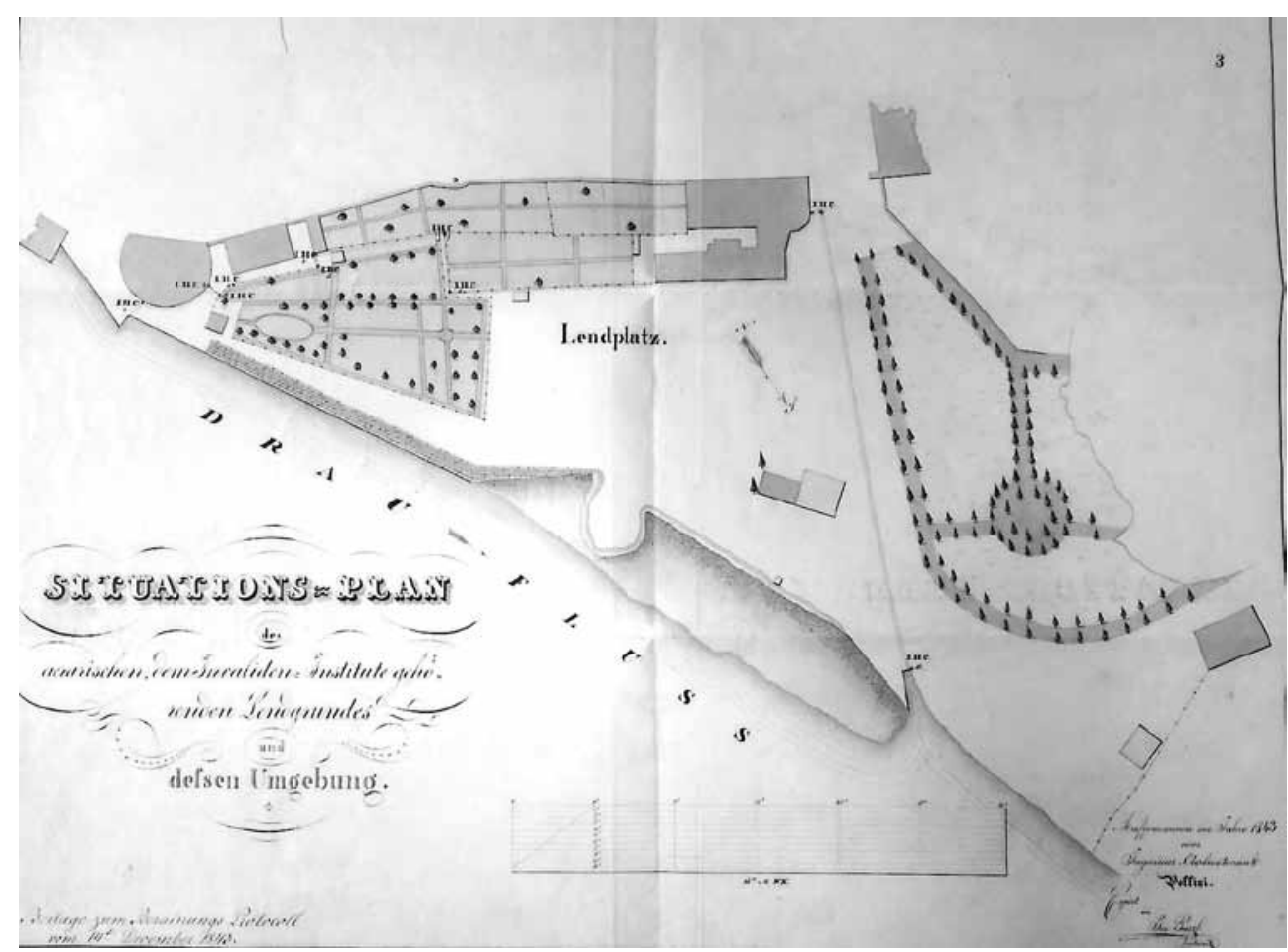

Slika 5. Plan gradske luke na Dravi u Ptuju iz 18. stoljeća (lent, lenštat). (Pokrajinski arhiv u Ptuju)

Godine 1812. u bratovštinu je bilo učlanjeno ukupno 165 splavara, momaka te braće i sestara, a za vrijeme predstojnika ceha Antona Pachernika 1829. bratovština je dobila ceški vrč na kojem je bila ugravirana dravska lađa. Tada je u ceh bio učlanjen 31 splavar te 128 momaka pomagača i braće podupirućih članova. ${ }^{41}$ Udruge splavara u 18. i osobito 19. stoljeću postojale su i u drugim splavarskim središtima na Dravi između Libeliča i Dupleka.

Uz Ptuj, kao glavno trgovačko središte s velikom uređenom lukom na Dravi, u 18. stoljeću jačaju i pristaništa nizvodno, sve do Osijeka. To se odnosi već na Ormož, gdje se 1704. spominje lenta (pristanište), koja ima i jednog stalnog za-

$\overline{41}$ Carica Marija Terezija 3. 11. 1773. potvrdila je listinu Splavarskom cehu (zadruzi) u Vuzenici. Splavarske zadruge uspostavljene su u Vuzenici i još nekoliko mjesta na Dravi od 1772., a tu listinu potvrdio je nadbiskup (nadškof) Karl Michael Attems 1773. godine. Franjo PAHERNIK, Šajke in splavi na Dravi, o.c., 2-3. Cehovi su imali svoje vodstvo (na čelu je bio predstojnik ili cehmešter) i svoja pravila, pa i organiziranu socijalnu brigu o svojim članovima. Vuzenička splavarska bratovština prestala je s djelovanjem 1914. godine. Maja KANOP - negdaj plovna reka, o.c., 186-187. 
poslenika (vjerojatno na mitnici). ${ }^{42}$ Priručno pristanište uređeno je i kod Borla, a velika lenta postojala je kod Varaždina, koja se spominje u više dokumenata iz 18. stoljeća. ${ }^{43} \mathrm{U}$ to doba glavni tok Drave nalazio se tik uz središte Preloga, pa je i tu djelovalo pristanište (portus Dravae), gdje su uglavnom pristajale šajke s merkantilnom robom, a splavari su imali postaju kod Otoka. ${ }^{44}$

Položena tada na granici prema Osmanskom Carstvu, od kraja 17. stoljeća veće značenje $u$ trgovini Dravom i Murom dobivaju naselja na sutoku Mure i Drave - Legrad, Kotoriba, Donja Dubrava i Drnje. To su najprije glavne logističke točke za opskrbu vojske u velikom Bečkom ratu, a potom u 18. stoljeću, pa sve do Drugoga svjetskoga rata, glavna poslovna središta splavarstva na Dravi, što posebice vrijedi za Donju Dubravu. Kao što je zapisao znameniti putopisac Friedrich Wilhelm von Taube (1728. - 1778.), „Kupa i Sava dovode ovamo (u luke Zemun i Beograd) mnogobrojne lađe, barke i splavi iz Hrvatske i Kranjske s njemačkom i talijanskom robom; Dravom i Dunavom dolaze lađe iz Štajerske, Mađarske i Austrije s mađarskom, njemačkom, francuskom, nizozemskom i engleskom robom. Čim se roba istovari i smjesti u magazine, lađe se natovare turskom robom i šalju natrag. Neke lađe (splavi) se ovdje i prodaju i zbog teške plovidbe uz rijeke ne vraćaju se natrag prema Njemačkoj." O važnosti tadašnjega riječnog prometa Drago Roksandić zaključuje: „Ako se izuzme stoka, koja se tjerala i Dravu prelazila na gazovima, većina druge robe morala se u to doba prevoziti rijekama, koliko god taj prijevoz bio spor i nesiguran. Naime, još uvijek je bio brži i pouzdaniji nego bilo koji drugi. ${ }^{\prime \prime 5}$

Kao glavno strateško (s velikom zrinskom utvrdom) i gospodarsko središte na sutoku Mure i Drave etablirao se Legrad, u kojem su obrtničke bratovštine i cehovi počele djelovati već od kraja 15. stoljeća. Tu je i u 18. stoljeću bilo glavno središte regionalne trgovine, a dobar dio robe prevozio se šajkama i splavima Dravom i Murom. U Legradu je djelovala i radionica šajki (kompi) i lađa (čona), a bilo je i uređeno oveće pristanište na Dravi (lenta). U 18. stoljeću u Legradu je djelovalo pet velikih cehova, a jedan od njih bio je šajkaški ili lađarski ceh. Povjesničar Legrada, Jenö Haller, navodi da je legradski šajkaški ceh dobio svoja pravila (artikuluše) 1717., a potpisao ih je kralj Karlo III. ${ }^{46}$

\footnotetext{
42 Boris GOLEC, Ormož v stoletjih mestne avtonomije, 1331.-1849., Ljubljana, 2005., 154.

Mirko ANDROIĆ, Neke značajke razvoja Varaždina u 18. stoljeću, Varaždinski zbornik, 1181.-1981., HAZU, Varaždin, 1883., 212.

Dragutin FELETAR i dr., 750 godina grada Preloga, 1253.-2014., Meridijani, Prelog, 2015., 446-447.

Wilhelm von TAUBE, Historische und geographische Beschreibung des Königreiches Slawonien und des Herzogthums Sirmien, I.-III., Lepzig, 1777.-1778., 94-95; Drago ROKSANDIĆ, Drava u očima Jozefinista, Ekonomska i ekohistorija, 7, Zagreb, 2011., 35. 


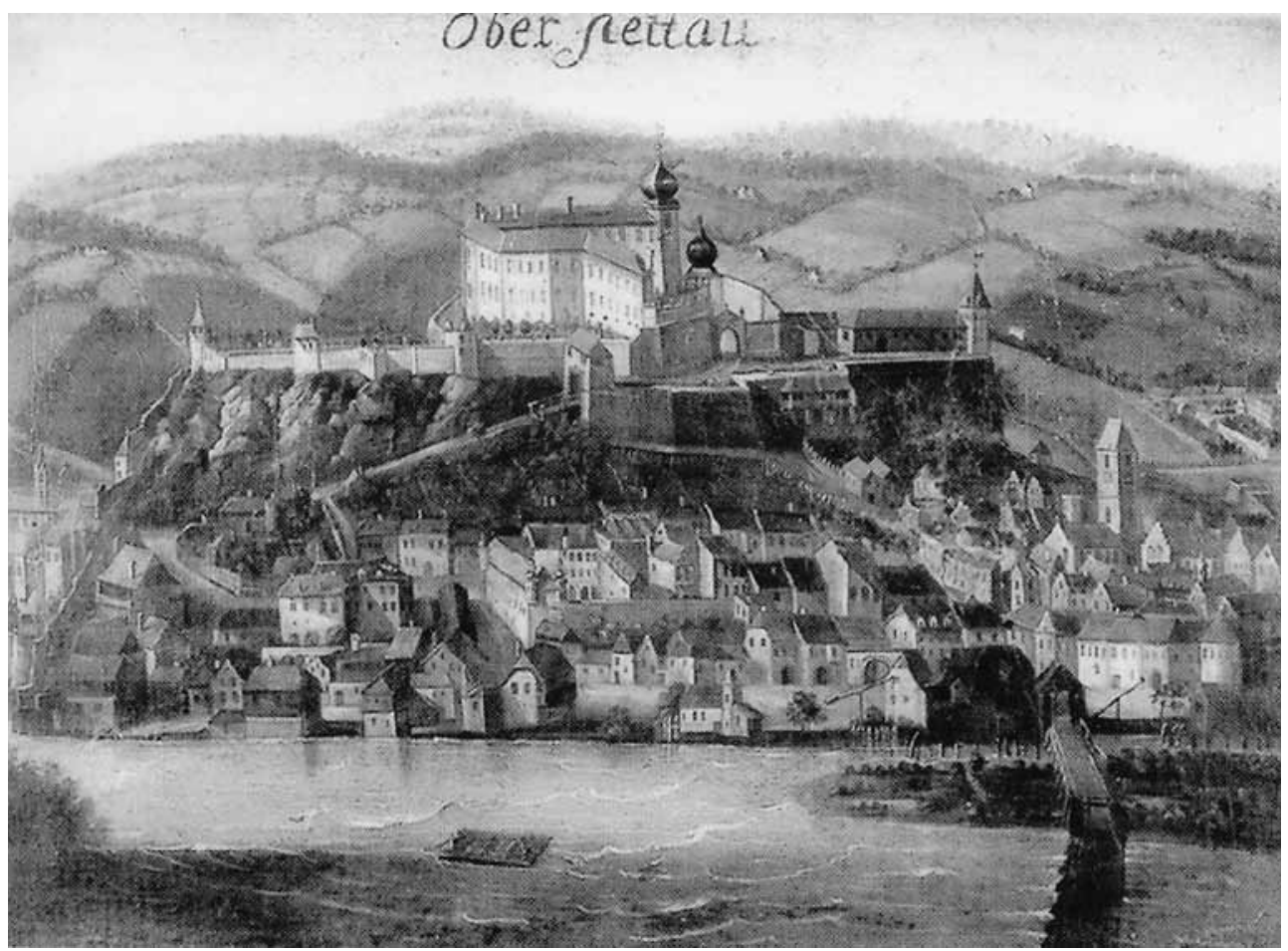

Slika 6. Veduta baroknoga Ptuja - na Dravi se vidi pontonski most i dolazak splavi - dokument iz 1687. godine (Pokrajinski arhiv u Ptuju)

O tomu piše i etnolog Ferencz Gönczi 1895.: „Dok je još Međimurje bilo bogato šumama, drvo se je transportiralo Murom i Drvom u udaljene krajeve (iako već tada i iz Štajerske). Krajnji je cilj bio Osijek. Otpremu su obavljali šajkaški i lađarski cehovi. Pravila legradskog šajkaškog ceha potvrdio je 1717. car Karlo III. Danas Međimurje više nema višak drveta, dapače drveta je premalo, pa se ono Dravom doprema splavima iz Štajerske i Koruške. ${ }^{47}$ Šajkaško-lađarski ceh postojao je i u Donjoj Dubravi, a najvjerojatnije i u Drnju.

Glavna trgovačka pristaništa na Muri u Međimurju bili su Mursko Središće i osobito Kotoriba. Murom su uglavnom plovile šajke s trgovačkom robom, a

ih je ponovno potvrdio 1717. godine. Jenö HALLER, Povijest Legrada, Meridijani, Legrad, 2016., 135 (original na mađarskom tiskan 1912.).

47 Ferencz GÖNCZI, Međimurje - ljudi, vjerovanja, običaji, Čakovec, 1995., 161-162 (original na mađarskom tiskan 1895.). 
manje splavi s drvenom građom. Ta je rijeka sve do 19. stoljeća bila prometna žila kucavica Štajerske. Već u 14. stoljeću (oko 1380.) spominje se promet na čamcima, koje su uzvodno vukli konji. Glavna središta splavarenja na Muri bila su Murau, Judenburg, Knittelfeld, Leoben, Bruck, Frohnleiten, Graz, pa Ernovž, Cmurek i Radgona te nizvodno Ljutomer, Sveti Martin na Muri, Mursko Središće i Kotoriba. Uz trgovinu drvnom građom, šajkaši su osobito prevozili sok, vino, med, žito i drugu robu. Splavarsko-lađarski ceh djelovao je u Radgoni, a kasnije je osnovan i u Kotoribi. ${ }^{48}$

U Kotoribi je pristanište (lenta) na Muri uređeno uz kotoripsku utvrdu, koju su dobrim dijelom izgradili još Zrinski. Prijevozom robe dijelom je na Muri rukovodila kotoripska trgovišna općina, osobito prema Legradu. U Kotoribi je početkom 18. stoljeća osnovan i posebni šajkaški red (ceh). U znamenitim Kotoripskim protokolima ili zapisnicima trgovišnog magistrata 1724. se u šajkaškom redu spominju 24 šajkaša i splavara, kojima je rukovodio cehmešter. Broj šajkaša povećavao se, a 1730. definirana je cijena prijevoza šajkama Murom do Legrada (dio je išao i u trgovišnu kasu). Čini se da je kotoripski šajkaški ceh bio poslovno i organizacijski usko povezan sa šajkaško-lađarskim cehom u Legradu. ${ }^{49}$

Na Dravi i Muri, na šajkama i splavima, našla se najraznovrsnija roba, pogotovo $\mathrm{u}$ vrijeme barokne obnove u 18. stoljeću. Kao svojevrsni raritet navest ćemo prijevoz splavima umjetničkih djela, pogotovo onih namijenjenih za opremu baroknih crkvi, kojih se u to doba mnogo gradilo u Međimurju i Podravini. I neki vrlo vrijedni oltari varaždinskih crkvi stigli su na splavima do gradske lente, a potom kolima do samih crkvi. Primjerice, to se odnosi na oltar franjevačke crkve, koji je izrađen u Mariboru (1699. - 1702.), te veliki oltar isusovačke crkve (1737.) također u Mariboru itd. ${ }^{50}$ Jedan od najvećih i najljepših baroknih oltara u sjeverozapadnoj Hrvatskoj, onaj u župnoj crkvi sv. Jakoba u Prelogu, izradili su majstori Veit Könniger i Joseph Hermann u Grazu 1768. godine. Oltar je na splavima spušten Murom do Legrada, a zatim su šajku vukli ljudi i konji Dravom uzvodno do priločke crkve. ${ }^{51}$

\footnotetext{
Miha KOSI, Potujoči srednji vek, o.c., 157-158.
}

49 Pravilima šajkaškoga reda (ceha) u Kotoribi bilo je određeno da djetići uče šajkaški zanat najmanje tri godine. Lidija KELEMEN, Međuodnos rijeke i naselja: rijeka Mura i trgovište Kotoriba u 18. stoljeću, Donjomeđimurski zbornik, 3, Meridijani, Prelog, 2016., 34-35; Lidija KELEMEN, Trgovišta Krapina i Kotoriba u 18. stoljeću, Meridijani, Samobor, 2017., 141-143.

50 Ivan OBADIĆ, Međuodnos ljudi i rijeke na području varaždinske Podravine, o.c., 308-309.

51 Dragutin FELETAR i dr., 750 godina Prelog, o.c., 446-447. 


\subsection{Organiziranost i značenje splavarstva na Dravi u 19. i 20. stoljeću}

Zlatno doba splavarstva na Dravi bilo je svakako 19. stoljeće, iako gustoća prometa (prvenstveno trgovine drvom) nije bila znatnije manja ni u razdoblju između dvaju svjetskih ratova. Na strukturu prijevoza roba ipak je bitno utjecala izgradnja makadamskih cesta, a pogotovo željeznica od sredine 19. stoljeća. Transverzalna željeznička veza Beča s Trstom izgrađena je vrlo rano, tako da Maribor dobiva prugu do Celja već 1847 . godine. Na to se nadovezuje i pruga od Budimpešte preko Kotoribe i Čakovca na Pragersko 1860., dok je longitudinalna željeznica dravskim kanjonom od Maribora prema Celovcu puštena u promet 1863. godine. Moderniji i mnogo brži cestovni i željeznički promet utjecao je na postupno smanjivanje, a u drugoj polovici 19. stoljeća i gotovo potpuno napuštanje prijevoza merkantilne i slične robe Dravom i Murom. Starinske specijalne splavi ili šajke, koje su bile zapravo male pokretne prodavaonice, otišle su u povijest.

Splavarstvo, koje je prevozilo sve više rezane i tesane građe, održalo se, jer je bilo jeftinije zbog prijevoza velikih količina drva, pa i odlično organizirano. U određenom smislu, željeznica je poslovno surađivala s dravskim splavarstvom, jer je drvna roba lakše i brže stigla do krajnjeg kupca s pristaništa na Dravi, Dunavu, Tisi i Begeju. Emitivno područje drva između Libeliča i Dupleka, gdje se uglavnom s Pohorja i Kozjaka (Kobanskog) drvna građa doprema do pristaništa (lenti) na Dravi, sve se uspješnije radno i poslovno organizira, pa u određenom smislu i profesionalizira. Računa se da se izričito splavarstvom (fljojsarstvom) na tom dijelu Drave već početkom 19. stoljeća profesionalno bavilo više od 200 ljudi, a povremeno i nekoliko tisuća (u cijelom lancu od sječe do prijevoza Dravom). ${ }^{52}$ Kao glavno sabirno (a dijelom i distributivno) pristanište etablira se lent $\mathrm{u}$ Mariboru (dok Ptuj u tom smislu gubi na značenju). S druge strane, nizvodno na sutoku Mure u Dravu početkom 19. stoljeća javlja se novo glavno poslovno središte splavarstva (fljojsarstva) - Donja Dubrava. Tu je 1828. godine osnovana tvrtka za trgovinu drvom Ujlaki-Hirschler, koja se do početka 20. stoljeća razvila u najvećeg distributera drvne građe na ugarskom, hrvatskom i južnoslavenskom prostoru..$^{53}$ Sinergija sve bolje organizirane eksploatacije drva u slovenskom porječju Drave, s velikom poslovnom ulogom mariborskog lenta,

\footnotetext{
52 Maja KANOP, Drava - negdaj plovna reka, o.c., 159-170; Franjo CIMERMAN, Obrt u Međimurju, Čakovec, 1998., 158-160.

53 Dragutin FELETAR, Hrvoje PETRIĆ i dr., Općina i župa Donja Dubrava, Donja Dubrava, 2013./2014., 99-103; Dragutin Em. ŠAFAR, Donja Dubrava između dva rata, Čakovec, 1991., 55-59; Slaven UJLAKI, Donjodubravski plemenitaši - obitelj Hirschler-Zalan, Donjomeđimurski zbornik, 3, Prelog, 2016., 104-107.
} 


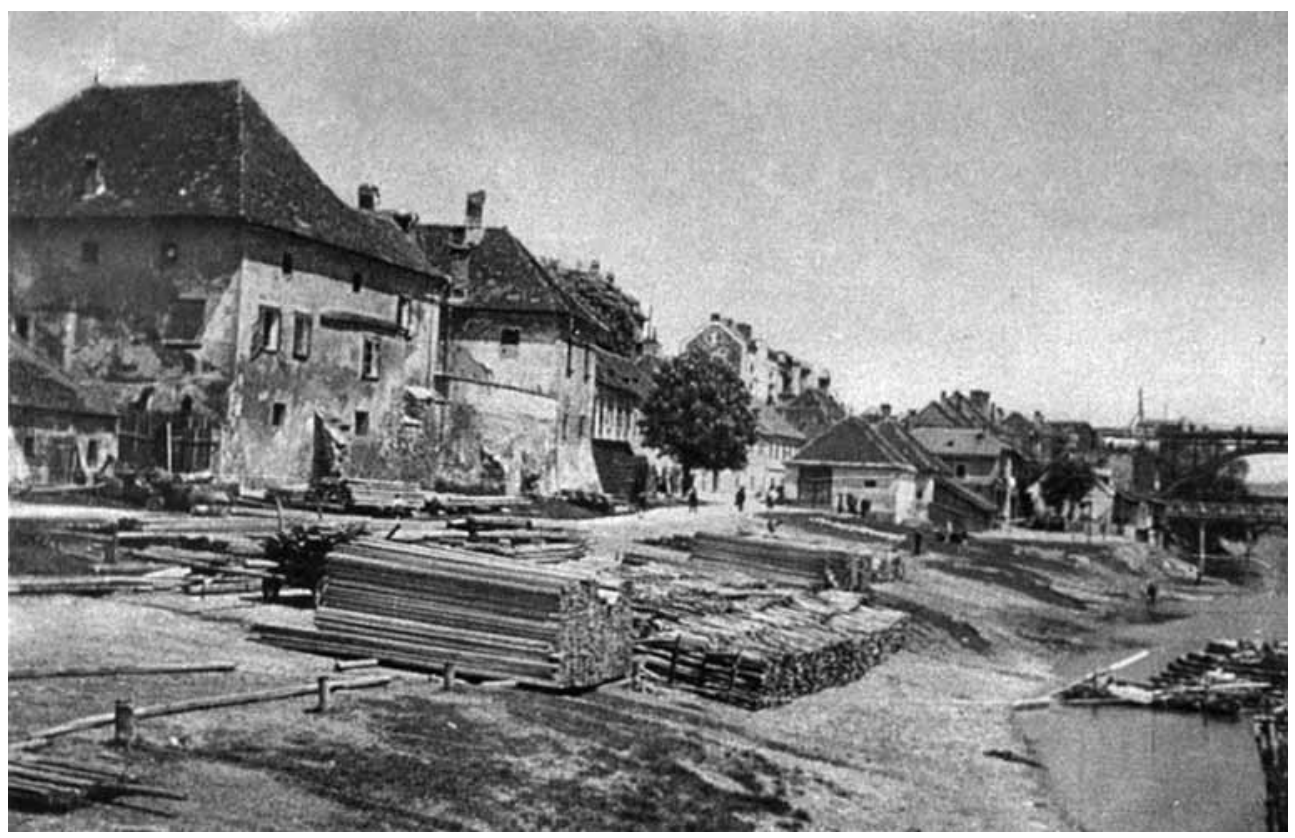

Slika 7. Lent u Mariborskim Benetkama - snimljeno potkraj 19. stojeća (Drava nekoč in danes, 2000.)

te odlično poslovno posložene trgovačke tvrtke drvom iz Donje Dubrave, rezultirala je napretkom splavarstva na Dravi i njegovim održanjem sve do početka Drugoga svjetskog rata.

Poljoprivredna gospodarstva (kmetije), koja su ojačala nakon ukidanja kmetstva, u drugoj polovici 19. stoljeća masovno osnivaju male pilane (žage). Njih je na Pohorju i Kozjaku (Kobanskom) i okolnim šumskim predjelima uz Dravu tada nastalo na stotine. Uglavnom su te kmečke žage bile na vodenu energiju brdskih potoka, ali kasnije su se koristili i parni strojevi te u prvoj polovici 20. stoljeća (pogotovo nakon izgradnje HE Fale, 1913. - 1918.) i električna energija. Gotovo svako veće domaćinstvo imalo je po jednu žagu, a ponegdje i dvije - pogotovo u Ribniško-lovrenškem podolju. Pilile su se grede, daske, letve i druga drvna građa, ali radili su se i kolci za vinograde, druga drvna galanterija te se kalalo i pripremalo drvo za ogrjev. Do kraja 19. stoljeća već se prodavalo vrlo malo oguljenih balvana, pa su se i splavi uglavnom spravljale od rezane drvne građe. ${ }^{54}$ Maja Kanop navodi da je 1825. samo na Lovrenškem Pohorju bilo 37 malih pi-

54 Maja KANOP, Načini živlenja prebivalcev Podravja - materialna kultura, Drava nekoč in danes, Založba Obzorja, Maribor, 2000., 128-129. 
lana (žaga), da bi se do 1880. njihov broj povećao na 80, odnosno 1910. godine na 84 žage. Krajem 19. stoljeća, kada je trgovina drvom ovdje dosegla vrhunce, broj pilana samo na Pohorju popeo se na više od 400 žaga..$^{55}$

Masovna sječa šuma, započeta na kraju postojanja feudalnih posjeda (koji su se tako spašavali od bankrota, pogotovo neposredno nakon ukidanja kmetstva), nastavljena je i na malim seljačkim šumskim posjedima, a znatne revire šuma sve više kupuju i veliki trgovci drvom i poslovni ljudi, pogotovo iz Maribora, glavnih pristaništa na Dravi, Donje Dubrave i drugih središta trgovine drvom. Uza žagarstvo, razvija se niz zanimanja koja su vezana uz promet drvom: vrlo su cijenjeni drvosječe, a posebno meštri koji su izvlačili drvo iz šuma te obavljali prijevoz do pilana, a potom do pristaništa na Dravi. To su bili tzv. foringaši, koji su ostvarivali i povoljne zarade, a bili su i zadružno (cehovski) organizirani. Posao su uglavnom organizirali trgovci drvom na veliko, a najpoduzetniji su bili lesni trgovci iz Lovrenca na Pohorju, Ribnice, Vuhreda, Brezna, Trbonja i Selnice te, dakako, Maribora.

Posebnu ulogu imala su brojna pristaništa (lenti, lentštati) na Dravi, koja su prihvaćala drvnu građu i bila poslovna središta za organizaciju splavarenja i trgovinu drvom. U Muzeju splavarstva obitelji Šarman u Podvelki (Javnik) o tomu piše: „Največ prometa je bilo v pomladanskih in jesenskih mesecih, ko je imela Drava dovolj vode. Največ splavov je otplulo iz Dravograda, saj je bilo tam zbirno mesto za les iz Mežiške in Mislinjske doline. Druga pomembna mesta, od koder su otpluli splavi, so bila: Libeliče, Vuzenica, Muta, Radnje, Vuhred, Brezno, Ožbalt, Lovrenc, Fala, Ruše, Selnica, Brestelnica in Maribor kod zadnja postaja za sestavljanje splavov. Splavi so pristajali v Mariboru, Ptuju, Varaždinu, Donjoj Dubravi, Barču, Moslavini, Osijeku. Ob Dunavi so pristajali tudi v Bogojevu, Vukovarju, Palanki, Čibu, Novom Sadu, Slankamenu in Beogradu. Nekateri splavi so pluli še po Aleksandrovem in Petrovem kanalu, po Tisi, Tamišu in Begejo.. ${ }^{156}$

Prema podacima iz 1938., dakle posve na kraju ere splavarstva na Dravi, iz lenta od Dravograda do Maribora otposlano je ukupno 1.167 splavi. Te je godine rastovareno (prodano) u Mariboru 37 splavi, u Ptuju 5, Varaždinu 33, Donjoj Dubravi 113 (iako je tamo splavarstvo već bilo na zalazu) te u ostalim lukama do Beograda i Smedereva još oko tisuću splavi. Po Tamišu se plovilo do Opova, a po Begeju do Zrenjanina (Petrovgrada), gdje je 1938. prodano drvo s 97 splavi. ${ }^{57}$ U organizaciji te trgovine ponajviše su sudjelovali trgovci iz Maribora i Donje

\footnotetext{
Maja KANOP, Drava - negdaj plovna reka, o.c., 160-161.

56 Zgodovinski pregled, pano, Muzej splavarstva Šarman, Javnik 5, Ožbalt.

57 Maja KANOP, Drava - negdaj plovna reka, o.c., 164-165.
} 


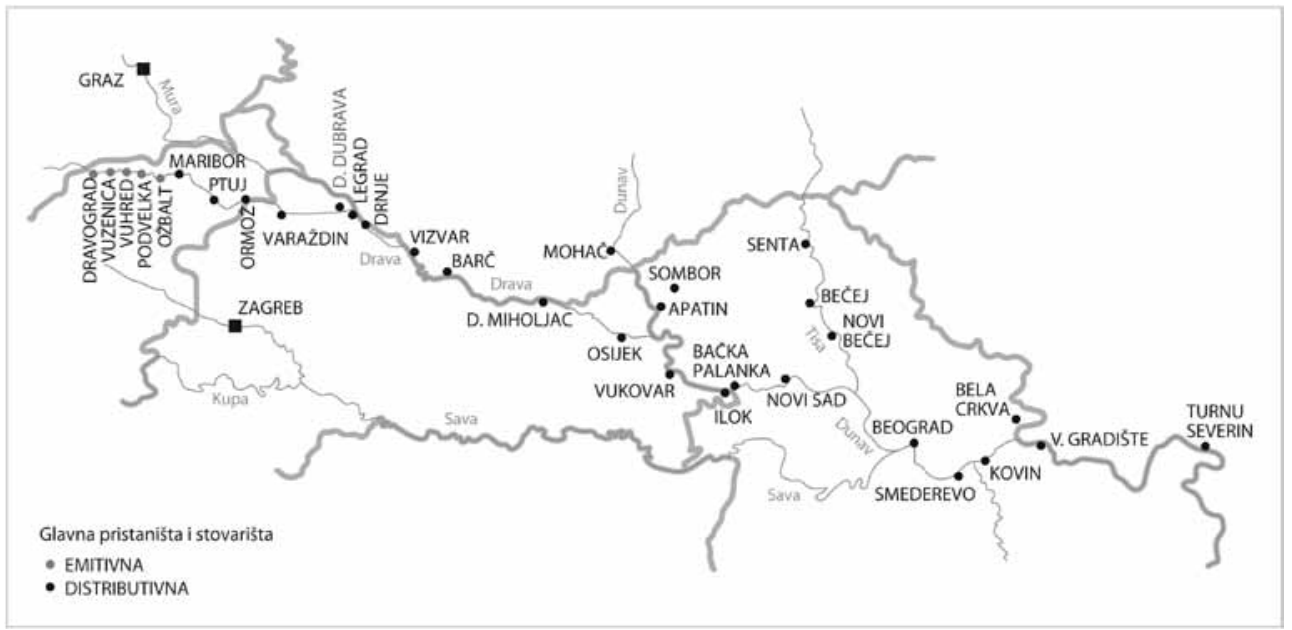

Slika 8. Glavna emitivna i distribucijska pristaništa za šajke i splavi u porječjima Drave i Dunava u južnoj Panonskoj nizini (D. Feletar, 2018.)

Dubrave, ali i iz Dravograda, Vuzenice, Podvelke i još nekih pristaništa na Dravi i Dunavu.

Opisujući najtežu plovidbenu dionicu za splavi između Dravograda i Maribora, Sašo Radovanovič piše da je „mariborski Pristan (lent) bil nekakšno splavarsko prometno križišče. Splavarjem, ki so pripeljali splave iz Dravske doline, so se pridružili splavarji z mariborskega konca, največ ih je bilo iz Dupleka, bližnje vasi ob Dravi. (...) V Kozjem Vrhu pri Dravogradu sta bila dva pristana, tudi v Spodnji Vižingi je negdanji splavarski pristan zaradi zajezitve Drave pod vodo. Vuhred se že od 15. stoletja omenja kot pomembno izhodišče za splavarstvo po Dravi. Tu so poleg splavov izdelavali tudi plitke štirioglate ladje, oziroma šajke. Do 2. svetovne vojne je to bil kraj eno od glavnih središč za trgovino s pohorskim lesom. Ob izlivu Vuhreščice v Dravo je bilo nekoč glavno pristanišče splavarjov, ki pa ga je ov zajezitvi Drave zalila voda. Nekoliko niže ležeče Brezno ob Dravi je bilo pred 2. svetovno vojno središče splavarstva v zgornji Dravski dolini. Pred zajezitvijo Drave je bil ob izlivu Brezniškega potoka v Dravo pristan, kjer so pristajali splavi - tu so jih tudi sestavljali. ${ }^{\text {"58 }}$

Od teškog rada i života drvosječa, foringaša i splavara najviše koristi imali su trgovci drvom, osobito velike tvrtke koje su nastale već u 19. stoljeću u Dravogradu, Mariboru, Donjoj Dubravi, Osijeku i na Dunavu. Najveće poslove vo-

$\overline{58}$ Sašo RADOVANOVIČ, Svet ob reki Dravi, Drava nekoč in danes, Založba Obzorja, Maribor, 2000., 84-85. 
dili su Hirschleri i Zalani iz Donje Dubrave, poznat je bio veletrgovac drvom Veržun iz Dravograda, dok su Steineri imali brojna predstavništva na Dunavu te u Bačkoj i Banatu. Veliki splavarski gazda, koji je i sam bio izvrstan splavar (kormanuš), Franc Šarman iz Javnika pri Ožbaltu, bio je jedan od najuspješnijih organizatora splavarskih posada, koje su plovile prvenstveno do Donje Dubrave, ali i dalje do Beograda. Šarmanove posade najviše su drvne građe vozile do Varaždina i Donje Dubrave, ali i do Šoderice (za Koprivnicu), Terezina Polja (za Viroviticu), Donjeg Miholjca, Belišća, Osijeka, Bogojeva, Vukovara, Bačke Palanke, Futoga, Beočina, Kamenice, Novoga Sada, Sremskih Karlovaca, Novog Slankamena, Beograda, Pančeva, Smedereva, Kovina, Bele Crkve, Titela, Srpskog

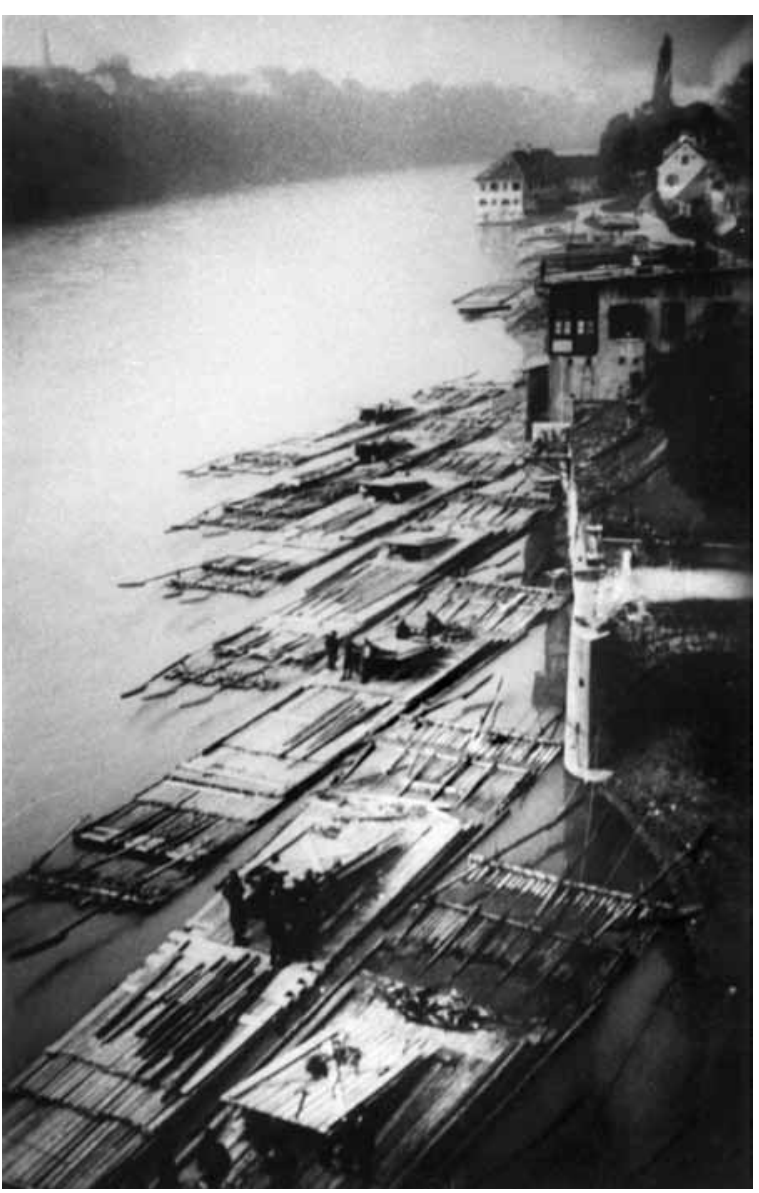

Slika 9. Ukotvljene splavi na lentu u Mariboru početkom 20. stoljeća (Splavarski muzej Šarman u Javniku) Itabeja, Ečke, Zrenjanina (Bečkereka), Novog Bečeja, Mola, Ade, Sente, Horgoša, Srbobrana, Vrbasa, Kule, Crvenke, Sivca, Sombora, Bezdana, Apatina i drugih mjesta. Zapravo, splavari sa slovenskih i gornjohrvatskih obala Drave, bili su glavni opskrbljivači drvnom građom velikih prostora južne Ugarske, Slavonije, Srijema, Bačke i Banata. ${ }^{59}$

Splavarstvo, pa i u kombinaciji sa šajkaštvom, postalo je velik posao već početkom 19. stoljeća, o čemu govore i dokumenti iz tzv. Göthove serije, 1810. - 1843.

59 Ivan VERBOTEN, Peter MACUH, Splavarstvo na Dravi in Donavi, Drava nekoč in danes, Založba Obzorja, Maribor, 2000., 208-209. 


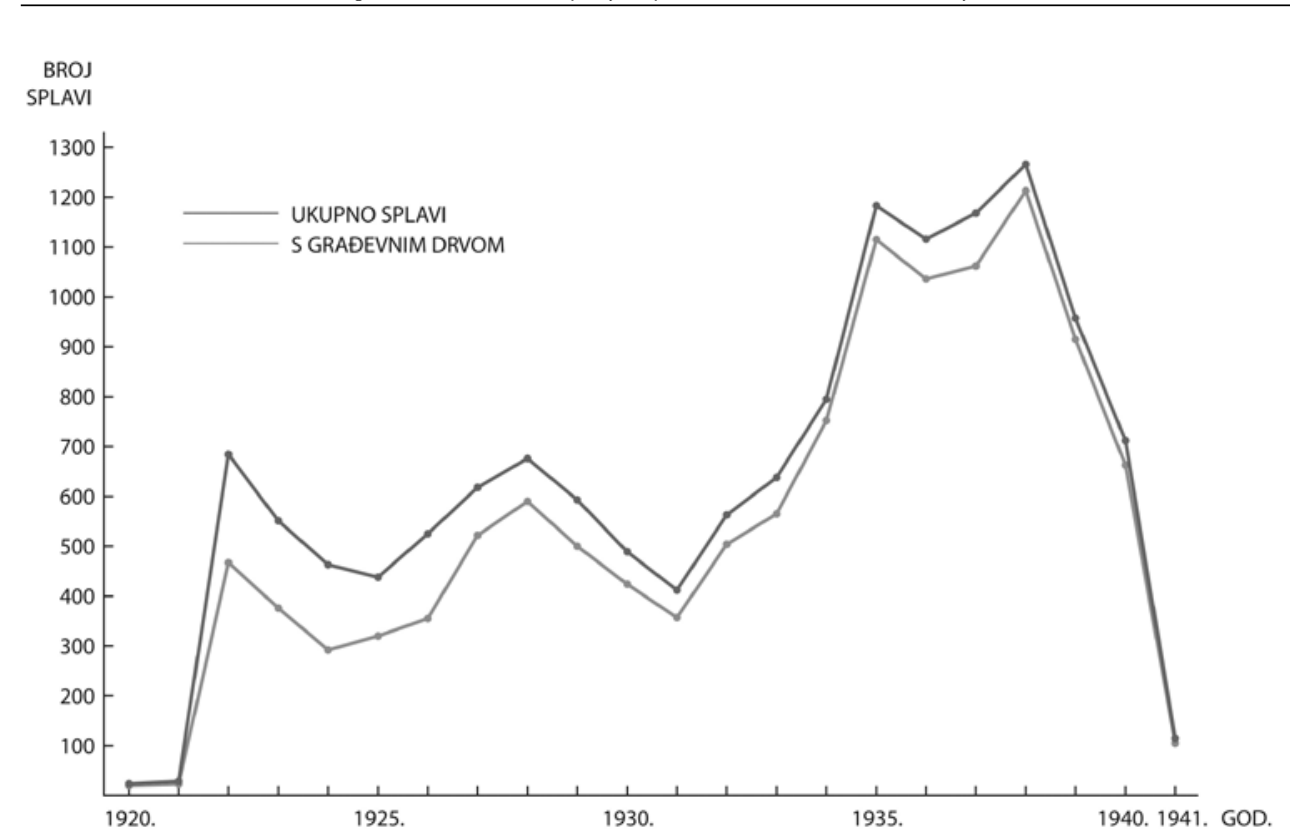

Slika 10. Kretanje broja splavi kroz „splavnicu“ na HE Fala kod Maribora od 1920. do 1941. godine (Franjo Pahernik, 1962.)

godine ${ }^{60}$ Tako je, primjerice, 1812. s Pohorja i Kobanskog na splavima Dravom isporučeno prema Hrvatskoj, Banatu i Srbiji (a trgovalo se i s tada osmanskim krajevima) 150 - 200 splavi drvne građe. Za 150 prosječno velikih splavi tada se moglo dobiti oko 85.000 gold dinara (zlatnih denara), što je donosilo čistu zaradu od oko 71.000 golddinara (kada se odbiju troškovi dostave). Uz to splavari su tih godina otpremili (uglavnom u mariborski i ptujski kraj) i oko 200 splavi bukovine, uglavnom za ogrjev, što je imalo vrijednost od oko 6.000 golddinara. Od prometa drvom već je tada živjelo više od 200 splavara i njihovih obitelji. Taj se promet drvom do kraja 19. stoljeća uvelike povećao, te je, uz poljoprivredu i rudarstvo, postao jedan od važnijih izvora prihoda stanovništva.

Mariborski povjesničar Rudolf Gustav Puff piše da je 1847. promet po Dravi bio vrlo živ: otplovilo je 700 - 800 šajki (s različitom robom) te $1.100-1.200$ splavi, uglavnom s drvnom građom i galanterijom. Na pristanu (lentu) u Mariboru 1850. pristalo je 800 šajki i 1.200 splavi, „ki so vozili les, nažagan na več kod 400 žagah, ki so bile raztresene po višjih legah" ${ }^{\prime 61}$ Radovanovič, pak, navodi podatak da je

\footnotetext{
60 Maja KANOP, Drava - negdaj plavna reka, o.c., 160.

61 Rudolf Gustav PUFF, Maribor, Založba Obzorja, Maribor, 1999., 35-37.
} 
godišnje po Dravi plovilo i po 2.000 splavi, koje su prevezle više od $200.000 \mathrm{~m}^{3}$ raznovrsnog drva, prvenstveno crnogorice. Taj se podatak odnosi na razdoblje prijelaza iz 19. u 20. stoljeće. ${ }^{62}$

Kada je početkom 20. stoljeća došlo vrijeme izgradnje prvih hidroelektrana na Dravi, velik posao trgovine drvom i dravsko splavarstvo valjalo je spašavati. Prvo je izgrađena HE Fala, uzvodno od Maribora, a graditelj Steiermärkische Elektrizitäts-Gesellschaft iz Graza pregovarao je s predstavnicima splavara i trgovaca već od početka izgradnje 1913. godine (elektrana je puštena u pogon neposredno poslije Prvoga svjetskoga rata). Tako je uz branu HE Fala izgrađena i prevodnica (splavnica) za prolaz splavi i šajki. Prevodnica je imala dvije komore, bila je duga $34 \mathrm{~m}$, a široka $7 \mathrm{~m}$. Tako je nastavljena splavarija (fljojsarija) i u razdoblju između dvaju svjetskih ratova, a velika većina splavi prošla je kroz prevodnicu HE Fala. S obzirom na to da se za prolaz plaćala i određena naknada, vodila se evidencija broja splavi i šajki. U razdoblju 1920. - 1941. kroz prevodnicu je prošlo gotovo 20.000 splavi, od kojih je prolaz platilo 14.025 splavi. To znači da je prosječno godišnje kroz HE Fala prošlo oko 900 splavi, koje su najvećim dijelom završile na tržištu nizvodno Dravom i Dunavom. Najveći broj splavi plovio je Dravom u razdoblju 1935. - 1938. godine. ${ }^{63}$

S obzirom na važnost, ali i brojne opasnosti splavarenja, vlasti su već od marijaterezijanskog merkantilizma nastojale regulirati, zaštititi i razvijati tu djelatnost. Tako su bili propisani pristanišni redovi, odnosno pravila plovidbe, tarife prijevoza, osnovna pravila ponašanja na vodi prigodom splavarenja i slično. Pravila je najčešće donosio carski i kraljevski okružni ured u Mariboru, a ponekad i više vlasti iz Graza, dok su neka pravila propisivale i same organizacije splavara i njihove zadruge. Tako je Pristanišni red (Lend-Ordnung) donesen već 1802. u Mariboru, a nadopunjen je kasnije nekoliko puta (1851., 1861.). Zbog prometa na Dravi, na mariborskoj obali bila je postavljena i posebna kuća upravitelja pristaništa (Lendhaus), koji je i čuvao robu u pristanu - pa otuda i pojednostavnjeno ime za pristanište - lent. ${ }^{64}$

Lend-Ordnung ili Pristanišni red trebalo je strogo poštivati, a za nepoštivanje su bile određene kazne, uglavnom u novcu. Na najvećim pristanima, primjerice

\footnotetext{
2 Sašo RADOVANOVIČ, Svet ob reki Dravi, o.c., 85-86.

63 U konjukturnim godinama 1935. -o 1939. kroz lent u Mariboru prošlo je godišnje i po $100.000 \mathrm{~m} 3$ drva, a u ostalim godinama po oko 50.000 m3. Tijekom 21 godine (1920. - 1941.) prošlo je više od milijun kubika drvne građe, što je bio velik trgovački posao i što je imalo veliko značenje za gospodarstvo Maribora i toga kraja. Franjo PAHERNIK, Šajke in splavi na Dravi, o.c., 16-26.

64 Na hrvatskom dijelu Drave (Varaždin, Donja Dubrava, Legrad) pristanište se zvalo lenta (ženskoga roda), kako Donjodubravčani i danas zovu utvrđeni dio dravske obale uz samo mjesto. Franjo PAHERNIK, Šajka in splavi na Dravi, o.c., 8-9.
} 


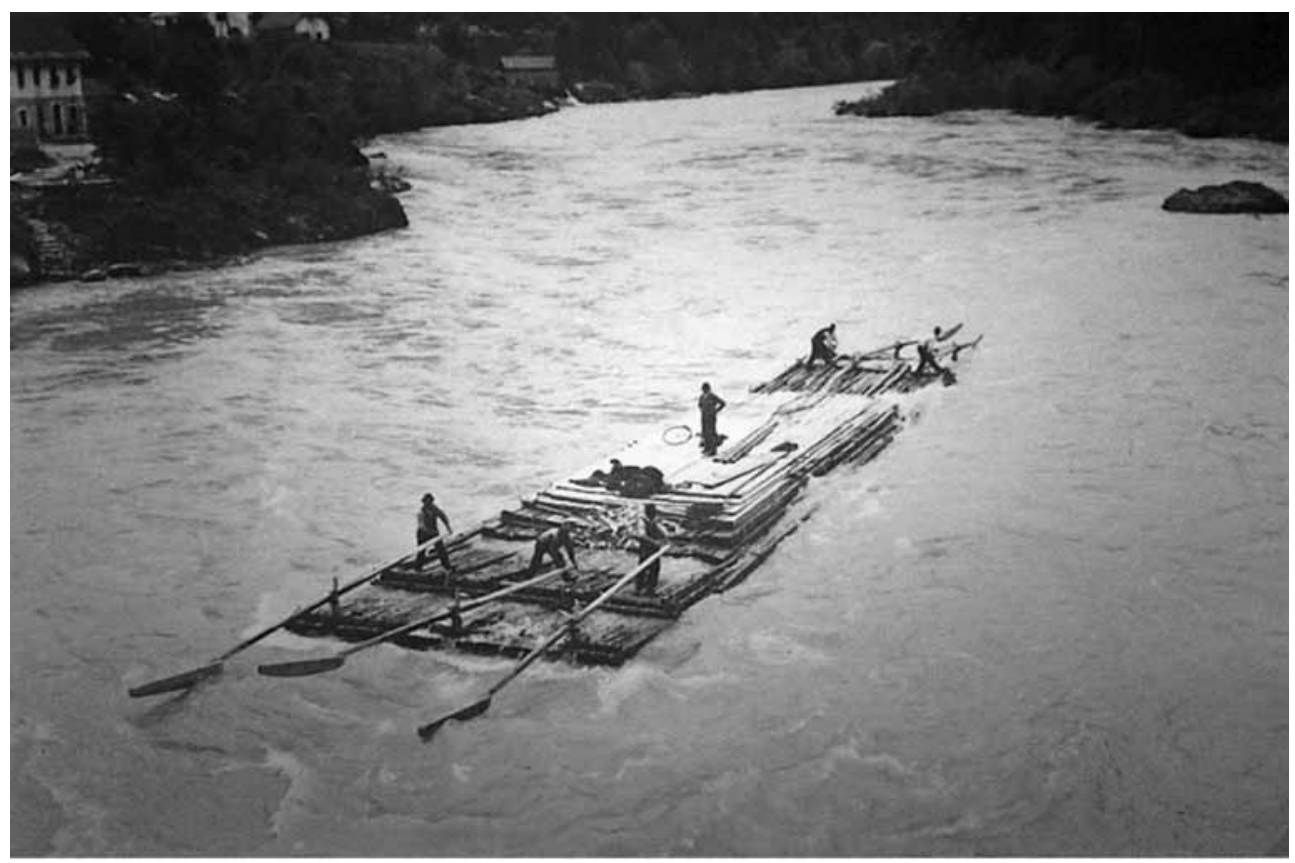

Slika 11. Splav na "rajži“ od Ožbalta prema Mariboru, između dvaju svjetskih ratova (Splavarski muzej u Javniku)

u Dravogradu, Ptuju ili Donjoj Dubravi (gdje je pravila propisivala sama tvrtka Ujlaki-Hirschler, ali i uprava Županije Zala), a pogotovu na lentu u Mariboru, drvo se moralo skladištiti samo na za to pripremljenim mjestima, a drvena građa slagala se po određenom redu i pravilima. Šajke i splavi trebale su se istovariti u roku od 48 sati od pristanka, a natovariti za najviše tri dana. Drvnu građu moglo se slagati samo do određene visine, $i$ to gusto, a ipak prozračno radi preglednosti. Ako drva nisu bila dobro naslagana, čuvar pristana (Lendhütter) dao je srušiti naslaganu robu, te je na trošak vlasnika ponovno poslagati. Dosta se trgovalo vinogradarskim koljem, koje je moralo biti vezano u snopove. Također je od svakoga splava ili šajke trebalo izdvojiti 4 svežnja drva ili kolja za prodaju siromašnim kupcima. Istovarenu je građu na uvijek prepunom mariborskom lentu trebalo što prije odvesti prema kupcima, a dovezenu građu složiti na splavi za daljnju plovidbu. ${ }^{65}$

$\overline{65}$ Snop drva na mariborskom lentu se 1860. prodavao po 3 do 4 golddinara. Franjo PAHERNIK, Šajke in splavi na Dravi, o.c., 9-10. 
Tablica 2. Broj splavi koje su prešle kroz prevodnicu (splavnicu) na HE Fala 1920. - 1941. godine

\begin{tabular}{|c|c|c|c|c|c|}
\hline Godina & $\begin{array}{l}\text { Splavi s } \\
\text { građevnim } \\
\text { drvom }\end{array}$ & $\begin{array}{l}\text { Splavi s kolcima } \\
\text { za vinograde }\end{array}$ & Ostale splavi & Ukupno & $\begin{array}{l}\text { Posto splavi s } \\
\text { građevnim drvom }\end{array}$ \\
\hline 1920. & 20 & 2 & 2 & 24 & 83,3 \\
\hline 1921. & 23 & 2 & 4 & 29 & 79,3 \\
\hline 1922. & 467 & 46 & 171 & 684 & 68,3 \\
\hline 1923. & 376 & 38 & 137 & 551 & 68,2 \\
\hline 1924. & 292 & 76 & 95 & 463 & 63,1 \\
\hline 1925. & 320 & 46 & 72 & 438 & 73,1 \\
\hline 1926. & 355 & 65 & 105 & 525 & 67,6 \\
\hline 1927. & 522 & 46 & 50 & 618 & 84,5 \\
\hline 1928. & 590 & 36 & 50 & 676 & 87,3 \\
\hline 1929. & 500 & 51 & 42 & 593 & 84,3 \\
\hline 1930. & 424 & 31 & 34 & 489 & 86,7 \\
\hline 1931. & 357 & 27 & 28 & 412 & 86,7 \\
\hline 1932. & 504 & 20 & 39 & 563 & 89,5 \\
\hline 1933. & 565 & 32 & 41 & 638 & 88,6 \\
\hline 1934. & 752 & 11 & 32 & 795 & 94,6 \\
\hline 1935. & 1.115 & 31 & 37 & 1.183 & 94,3 \\
\hline 1936. & 1.036 & 30 & 50 & 1.116 & 92,8 \\
\hline 1937. & 1.062 & 26 & 80 & 1.168 & 90,9 \\
\hline 1938. & 1.213 & 23 & 40 & 1.266 & 95,8 \\
\hline 1939. & 915 & 7 & 35 & 957 & 95,6 \\
\hline 1940. & 663 & 20 & 29 & 712 & 93,1 \\
\hline 1941. & 105 & 7 & 3 & 115 & 91,3 \\
\hline UKUPNO & 12.176 & 673 & 1.176 & 14.025 & 86,8 \\
\hline
\end{tabular}

Izvor: Dokumentacija HE Fala. Franjo Pahernik, Šajke in splavi na Dravi, Vuhred - Maribor, 1962., rukopis, 26-27

Mjesne općine, pogotovo $\mathrm{u}$ Mariboru, ubirale su posebne pristojbe za usluge na pristanima (lentima). Za to su bile propisane posebne tarifne liste, a pristojbe su se plaćale na mitnici pristana. Općina je svake godine davala vođenje mitnice u zakup, i to na javnoj dražbi (primjerice u Mariboru je 1861. isklična cijena bila 910 fl.). ${ }^{66}$ Prema tarifi, koju je 1889. godine donio mariborski carski i kraljevski

$\overline{66}$ Dokumenti: Tarife od 8. 1. 1851., te od 24. 12. 1861. godine. Franjo PAHERNIK, Šajke in splavi na Dravi, o.c., 9-11. 
namjesnik, određuje se plaćanje ležarine na dravskom lentu, $\mathrm{i}$ to dnevno $50 \mathrm{fl}^{67}$ Takve uredbe vrijedile su i za pristane u Dravogradu, Vuzenici i drugdje. Na pristanima duž Drave splavari su priređivali posebne svečanosti (i mise) na dan Sv. Nikole, svojega zaštitnika, a posebno je zanimljivo bilo i na Katarinskom sajmu, koji se svakog 26. studenoga održavao na pristanu u Ptuju. Tu su splavari izložili svoju drvenu robu, a najviše se trgovalo vinogradarskim koljem, daskama, letvama, tesanim gredama i drvnom galanterijom. ${ }^{68}$

$\mathrm{Uz}$ veće pristane, kao što je Dravograd, Vuzenica, Ožbalt, Maribor ili Donja Dubrava, bili su vezani i

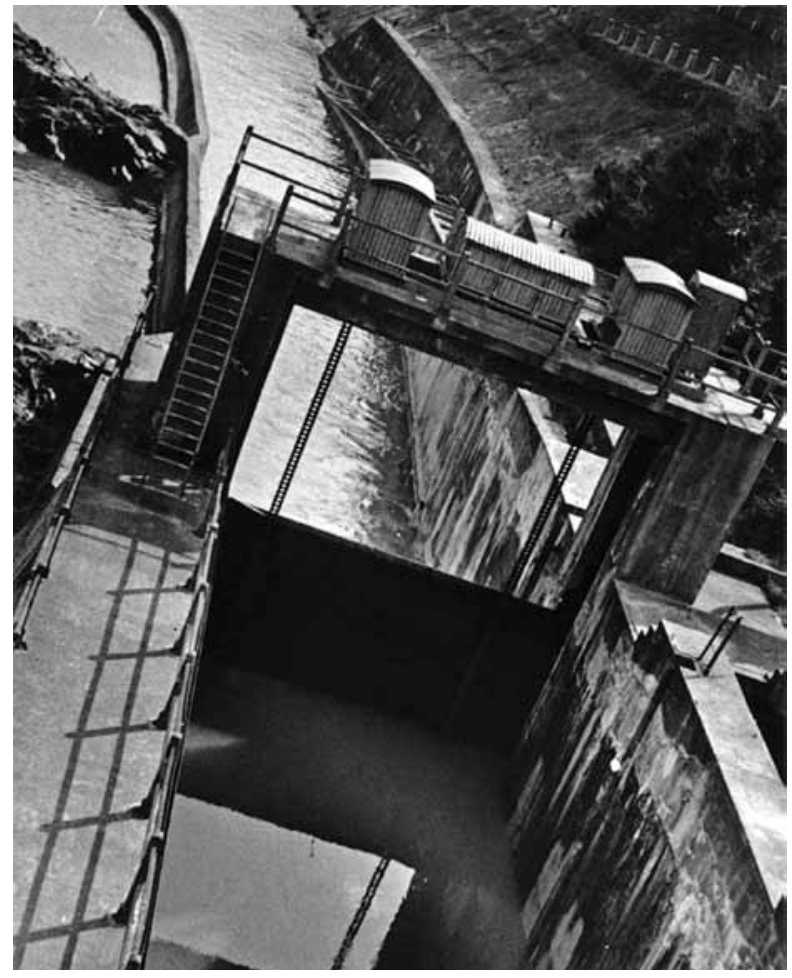

Slika 12. "Splavnica“ za propuštanje plovila izgrađena uz HE Fala mogla je primiti splavi do širine do $6 \mathrm{~m}$ i dužine do $32 \mathrm{~m}$ (foto-arhiv Dragutina Feletara) splavarski redovi ili cehovi, koji su kasnije prerasli u splavarske zadruge. Prvenstveni cilj tih organizacija bio je zaštititi članove od pretjeranog iskorištavanja splavara od strane veletrgovaca drvom, ali i pružati im i što bolju socijalnu zaštitu, te od poslodavaca ishoditi što povoljnije tarife za plovidbu. Osobito je poznat splavarski red ili bratovština u Vuzenici (kojoj je 1829. - 1835. predstojnik bio Anton Pachernik). Nakon Prvoga svjetskoga rata i ovdje splavari nisu imali svoju organizaciju, pa je osnovana splavarska zadruga. To je 1928. učinjeno i u Mariboru te 1933. i u Ožbaltu. ${ }^{69}$

$\overline{67}$ Listina od 11. 9. 1802., te tarifa od 22. 1. 1889. godine. Franjo PAHERNIK, Šajke in splavi na Dravi, o.c., 11-11.

68 Maja KANOP, Drava - negdaj plovna reka, o.c., 186-187.

69 Te su zadruge bile učlanjene u Zadružnoj zvezi u Ljubljani. Maja KANOP, Drava - negdaj plovna reka, o.c., 186-188. 
Pred Drugi svjetski rat osobito je uspješno djelovala Zadruga splavarjev Dravske doline r.z.z.o. u Ožbaltu. Učlaniti su se mogli svi splavari koji su plovili barem jednu godinu, plaćala se članarina (5 dinara), a godišnji promet te udruge bio je oko 10.000 dinara. Splavarska zadruga u Ožbaltu djelovala je najaktivnije 1933. - 1941. godine. U pravilima zadruge (prihvaćenim na „ustanovnom občem zboru“ 19. 1. 1933.) čitamo da "Zadruga ima namen: a. Raspečavati kmetijske pridelke in lesne izdelke svojih članov, b. Ustanavljati in vzdrževati zadružna skladišta, c. Oskrbovati svojim članom splavarske potrebščine, d. Pospeševati dobrobit svojih udov s tem da: - izdaje naredbe v povzdigo splavarstva; - daje v splavarskih zadevah svojim udom nasvete; - prireja poučne splavarske sestanke; - urejuje razmerje med delodajalcem in delojemalcem; - daje svojim udom podporo v slučajo bolezni, prezposlenosti in starosne onemoglosti.“ Zadružna članarina iznosila je 10 dinara. Pravila su potpisali načelnik Anton Ropič, namjesnik Anton Rozman i tajnik Franc Bregar. ${ }^{70}$

Cehovsko udruživanje brodara, splavara, lađara i šajkaša, pa kasnije i foringaša (prijevoznika na zaprežnim kolima), još iz 18. stoljeća, nastavljeno je i kasnije i u splavarskim središtima u Kotoribi, Donjoj Dubravi i Legradu. Međutim, o postojanju posebnih splavarskih zadruga u tim mjestima u razdoblju između dvaju svjetskih ratova - nema podataka (postojale su opće i vjeresijske zadruge). Šajkaški i splavarski red u Kotoribi djelovao je i u dobrom dijelu 19. stoljeća i imao je čvrsta cehovska pravila. Specifičnost je bilo osnivanje foringaškog reda u tom mjestu, koji je drvo (i drugu robu) prevozio uglavnom do Donje Dubrave (i obratno), Donjeg Vidovca, Legrada ili Murskih Križevaca preko Mure. Ceh je s trgovišnom općinom dogovarao cjenike prijevoza, a Zaladska je županija 1784. donijela posebne odredbe za što bolju kvalitetu obavljanja foringaških poslova. ${ }^{71}$ I u Legradu je tijekom 19. stoljeća nastavio djelovati stari Šajkaški ceh (s pravilima još iz 1717. godine), a brojni su bili i foringaši, jer su robu od legradske lente prevozili prema Koprivnici i Velikoj Kanjiži. ${ }^{72}$ Računa se da je Brodarski i splavarski ceh osnovan u Donjoj Dubravi tek početkom 19. stoljeća, kada je naglo porastao posao veletrgovine drvnom građom. Cehovska dokumentacija (pravila) nije sačuvana, ali postoji očuvan cehovski vrč iz 1834. godine (na njemu su simboli rječnog broda i fljojsa). Čini se da dobravski splavarski ceh ili eventualno

\footnotetext{
70 Zapisnik s ustanovne skupštine Splavarske zadruge u Ožbaltu, od 19. 2. 1933. godine (Pravila te zadruge registrirana su na sudu 20. 5. 1939.). Franjo PAHERNIK, Šajke in splavi na Dravi, o.c., 19-21; Maja KANOP, Drava - negdaj plovna reka, o.c., 186-188.

71 Lidija KELEMEN, Trgovišta Krapina i Kotoriba u 18. stoljeću, o.c., 146-148; Hrvoje PETRIĆ, Rijeka Drava i međimursko selo u novom vijeku - primjer Donje Dubrave (18. - 20. stoljeće), Podravina, 20, Meridijani, Koprivnica, 2011., 45-47.

72 Jenö HALLER, Legrad törtenete, Eszek, 1912., 81-84.
} 


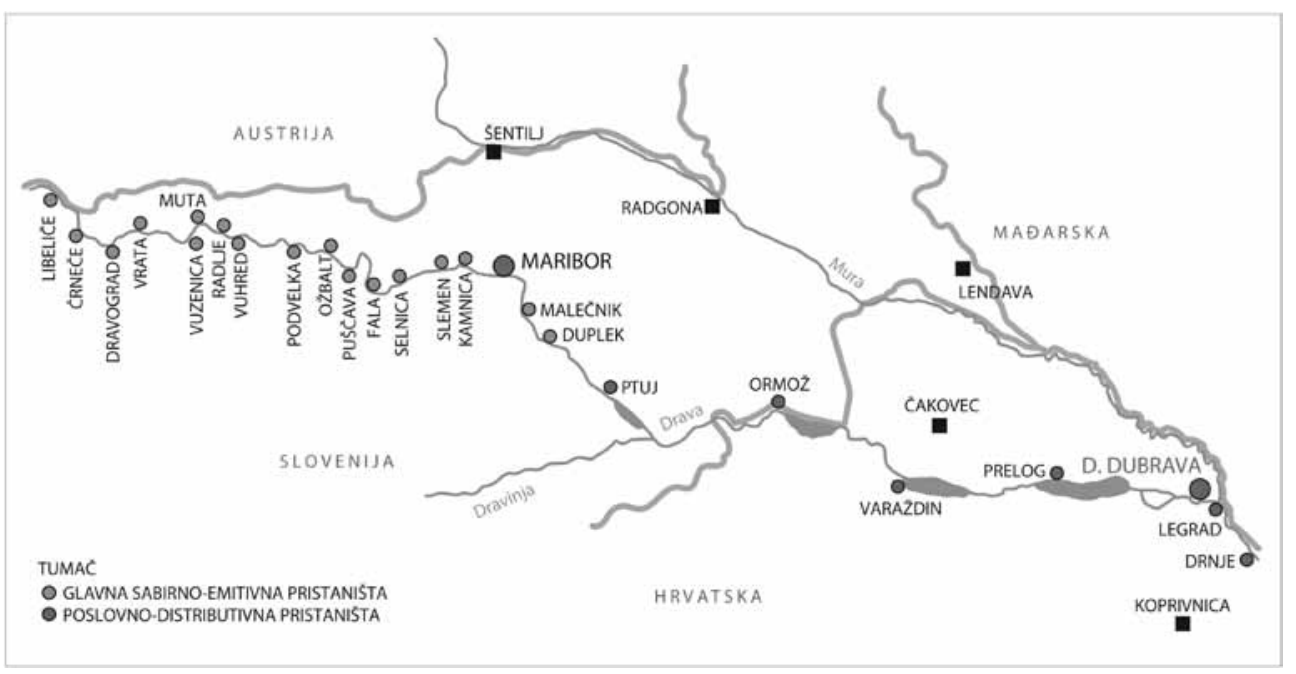

Slika 13. Glavne splavarske luke (lente, lenštati) od Libeliča do Drnja (D. Feletar, 2018.)

postojanje fljojsarske zadruge nije u Donjoj Dubravi bilo duga vijeka, jer je kompletnu organizaciju i brigu o splavarima i njihovim obiteljima preuzela, zapravo, najveća tadašnja tvrtka za veletrgovinu drvom na Dravi - Ujlaki-Hirschler i sin (osnovana 1828. godine). ${ }^{73}$

\subsection{Donja Dubrava - poslovno središte splavarstva (fljojsarstva) na Dravi}

Već na kraju 18., a poglavito u 19. i prvoj polovici 20. stoljeća, kao glavno poslovno središte splavarstva (trgovine i osnovne prerade drva) na Dravi u Hrvatskoj razvija se istočnomeđimursko mjesto Donja Dubrava. Razvoju te funkcije Donje Dubrave uvelike je pridonio geografski položaj na sutoku Mure u Dravu, kao i sve bolja prometna povezanost s tada glavnim gradskim središtima u okolici - Prelogom, Čakovcem i Varaždinom sa zapada, Koprivnicom i Ludbregom s juga te s Velikom Kanjižom i Čurgovom na sjeveru i istoku. Razvoju trgovine drvom tu su pridonijele i povoljne mjesne lolacijske prilike, jer se mjesto nalazi na samoj obali Drave i lako je bilo urediti pristanište (lentu). U ovom velikom naselju, koje je već 1857. godine imalo 2.602 stanovnika, bilo je dobro razvijeno obrtništvo, od kraja 18. stoljeća djeluju i cehovska udruženja, a razmjerno brzo razvila se i trgovina. Taj poslovni lokalni genius loci bio je razlogom što se Donja Dubrava već u 18. stoljeću uključuje i u lanac trgovine drvom koji je iz Štajerske

$\overline{73}$ Dragutin FELETAR, Hrvoje PETRIĆ i dr., Općina i župa Donja Dubrava, o.c., 77-78. 


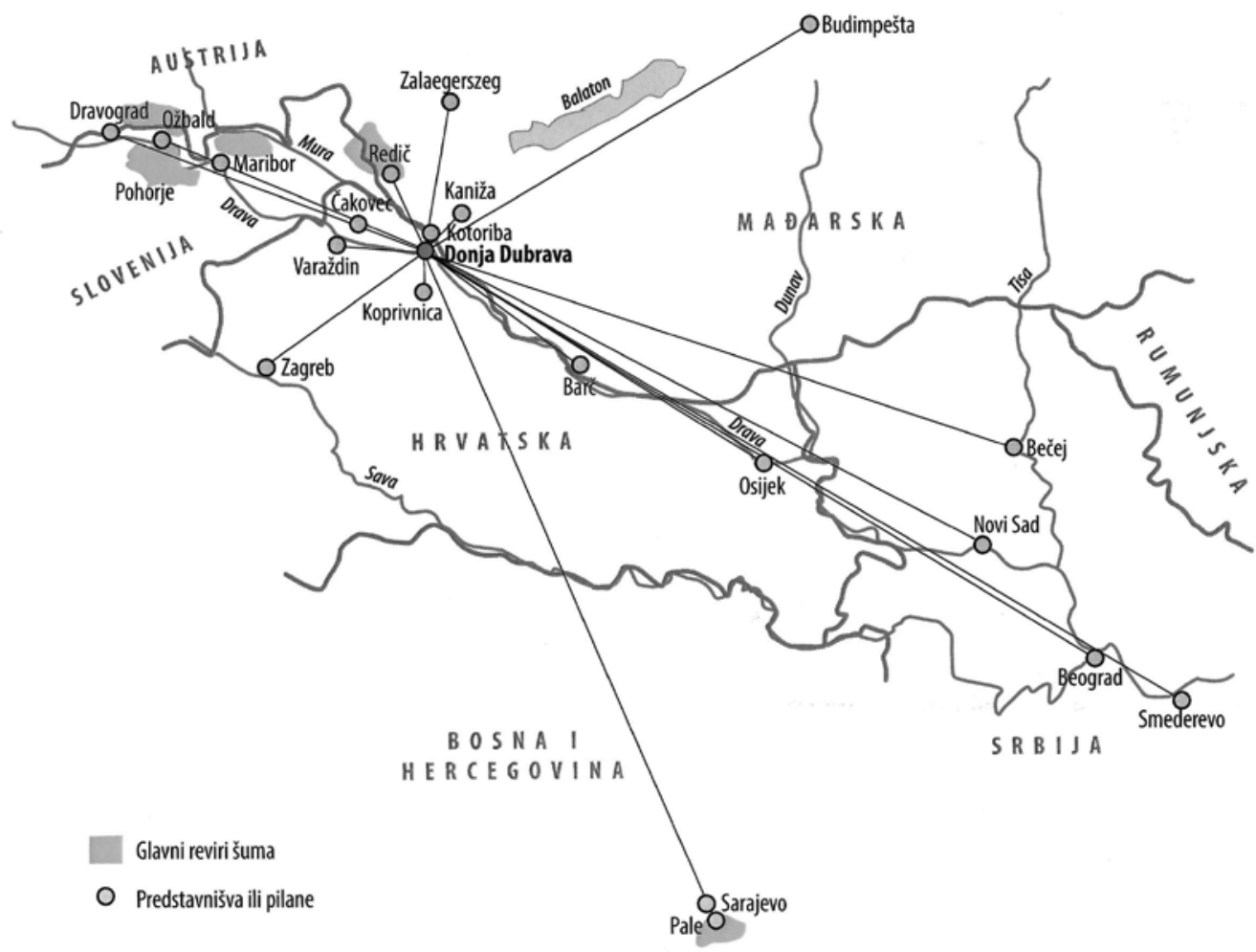

Slika 14. Predstavništva i skladišta tvrtke Ujlaki-Hirschler i sin - stanje 1920-ih godina (D. Feletar, 2018.)

(Slovenije) i Koruške Dravom ovuda strujao prema središtima Slavonije, južne Ugarske, Bačke i Banata. Donja Dubrava već tada postaje jedno od važnih pristaništa splavara, a mjesni trgovci polako se uključuju i u trgovačke poslove s drvnom građom, prvo za posve lokalne, a potom i za šire, regionalne potrebe. ${ }^{74}$

Računa se da je jednu od prvih značajnijih trgovina drvom (ali i drugom, merkantilnom robom) u Donjoj Dubravi otvorio krznarski obrtnik Jeronim (Remuš) Ujlaki (Novoselec), i to već krajem 18. stoljeća. Poslovalo se i s drvnom građom iz lokalnih izvora, jer su se tada sjekle bogate pridravske šume hrasta lužnjaka, ali poduzetni Jeronim Ujlaki sve se više uključuje i u poslove splavar-

74 Dragutin FELETAR, Petar FELETAR, Geografske značajke i stanovništvo, Općina i župa Donja Dubrava, Donja Dubrava, 2013./2014., 41-42. 


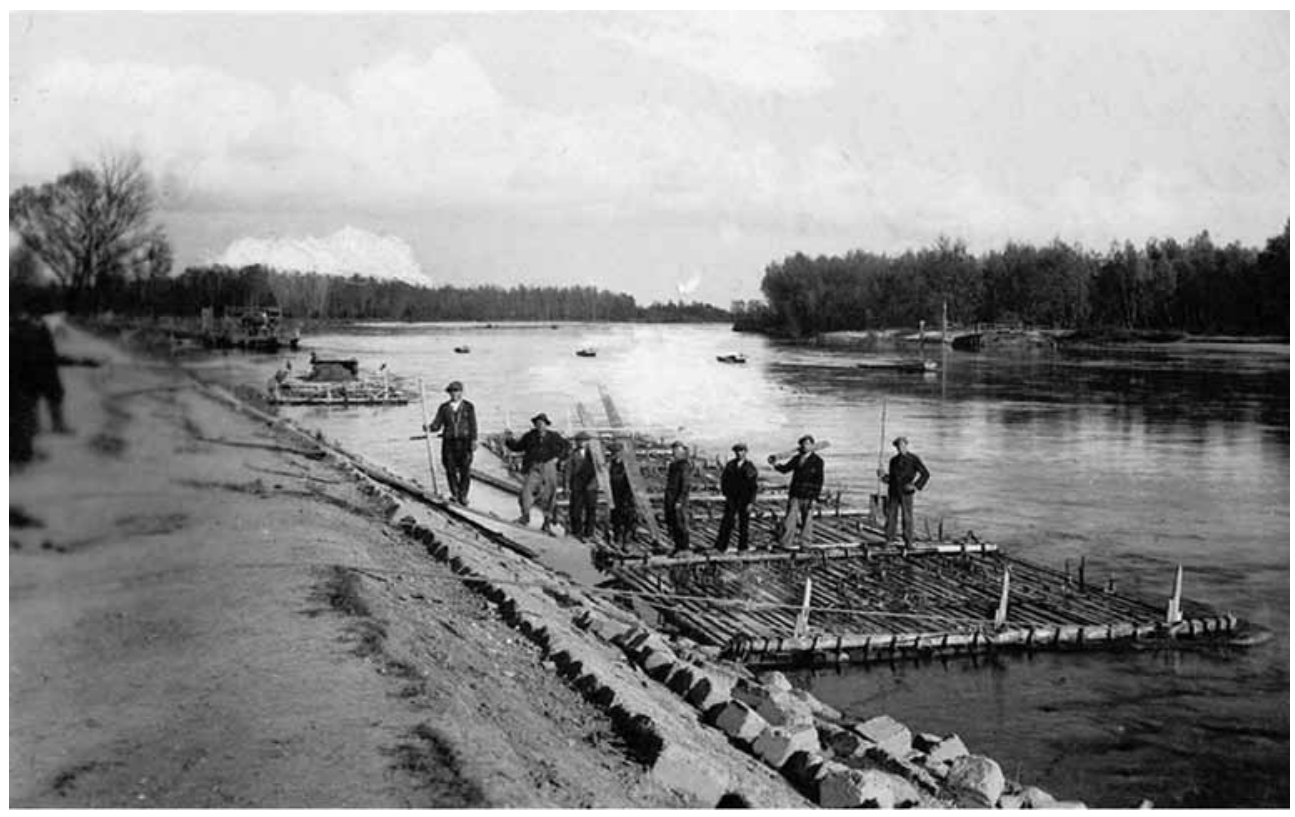

Slika 15. Dvije splavi pristale su na lentu u Donjoj Dubravi, snimljeno početkom 20. stoljeća (foto-arhiv D. Feletara)

stva Dravom, odnosno u suradnju sa slovenskim i drugim trgovcima. Poradi razvijenog obrtništva i veličine naselja, od kraja 18. stoljeća počinje u Donjoj Dubravi jačati i židovska zajednica. Židovi se tamo doseljavaju iz okolnih gradova, a prvenstveno iz mađarske Velike Kanjiže te iz Čakovca. Tako je 1820-ih godina u Donju Dubravu stigao i mladi, poduzetni Židov Julius Hirschler (1802. - 1877.). On se u početku bavio prodajom razne robe obilazeći dobravska kućanstva, a potom u središtu mjesta otvara malu trgovinu mješovitom robom. ${ }^{75}$

Uočivši sve veću važnost trgovine drvom koja se odvijala Dravom, Julius Hirschler i Jeronim Ujlaki počinju poslovno surađivati, te 1828. osnivaju zajedničku firmu za promet drvom i drvnim izdjelcima, koju su nazvali Ujlaki-Hirschler d.d. Time je počela uspješna poslovna donjodubravska priča, koja je trajala više od jednog stoljeća. Uspon obitelji Hirschler iz Donje Dubrave „prikazuje

75 Dragutin Em. ŠAFAR, Donja Dubrava između dva rata, o.c., 21-22. Neki podaci dokumentiraju da je u Donjoj Dubravi postojalo trgovačko društvo koje se još 1771. bavilo preprodajom drva, ali nije poznato da li je bilo u vlasništvu obitelji Ujlaki ili možda nekih Židova, koji su se počeli doseljavati u ovo mjesto. Nadbiskupski arhiv Zagreb, Kanonske vizitacije župe Donji Vidovec, Prot. 79/X.63-64. Nikola BENKO, Povijest župe u Donjoj Dubravi, diplomska radnja, rukopis, župni dvor Sv. Margarete, 13-14. 
tipičan put bogaćenja trgovaca u ovim krajevima tijekom 19. stoljeća. Obitelj je prošla svoj put od pokućarca do plemenitaškog naslova baruna“. ${ }^{76}$ Neki članovi obitelji Hirschler prerasli su u poslovne magnate regionalnoga značenja, te su obilježili razvoj i život Donje Dubrave kroz razdoblje 19. i prve polovice 20. stoljeća. ${ }^{77}$

Uskoro nakon osnivanja tvrtke, već 1840-ih godina, njenim vlasnikom postala je sama obitelj Hirschler. Jeronim Ujlaki i njegova supruga ubrzo su umrli, a njihov posao naslijedili su Julius Hirschler i žena mu Ivana Macherlup. Unatoč tomu ime tvrtke nikad se nije promijenilo, a dugo je djelovala pod imenom Ujlaki-Hirschler i sin (Ujlaky Hirschler und Sohn, Ujlaky Hirschler és fia). Jeronim Ujlaki imao je dva sina: Stjepan je bio gimnazijski profesor u Velikoj Kanjiži i umro je mlad, dok je Gašpar bio cijenjeni modni krznarski obrtnik u Parizu. Kada je on umro 1868., u Donju Dubravu stiglo je veliko nasljedstvo, ${ }^{78}$ koje su najvećim dijelom uspjeli prigrabiti Hirschleri. Taj je kapital uložen u razvoj tvrtke, što je uvjetovalo nagli uspon poslovanja. Hirschleri grade u Donjoj Dubravi desetak reprezentativnih poslovnih i stambenih zgrada, uskoro i parnu pilanu, te utvrđuju obalu proširujući pristanište $($ lentu $) .{ }^{79}$

Svoj zenit tvrtka Ujlaki-Hirschler i sin ostvarila je krajem 19. i početkom 20. stoljeća, a pod upravom sinova Juliusa Hirschlera - Leopolda (1840. - 1907.), koji je potkraj 19. stoljeća prešao na katolicizam i uzeo prezime Zalan, zatim Maximilijana ili Maksa (1841. - 1919.), te Jakoba (1845. - 1891.). ${ }^{80}$ Novo bogatstvo slilo se u blagajnu Hirschlerovih kada se 1870-ih Jakob Hirschler oženio bogatom mađarskom plemkinjom Adelom Presburger iz Körmenda. I taj je kapital uložen u razvoj dobravske tvrtke. Nakon smrti Jakoba Hirschlera 1891. godine Adela se preudaje za njegova brata Maksa, a nakon njegove smrti 1919. sama (sa sinom Rudolfom) vodi tvrtku do njezine propasti pred Drugi svjetski rat. Hirschleri i

$\overline{76} \quad$ Tijekom 19. stoljeća broj Židova u Donjoj Dubravi znatno se povećao: od 21 u 1857. na 49 u 1900. godini. B. BUNJAC, J. JOKU, V. MATOTEK, I. RUSAK, M. ŠESTAK, Pregled povijesti Međimurja, Ćakovec, 2013., 97-98.

77 Zvonimir BARTOLIĆ, Donja Dubrava u svojoj historiji, legendi i stvarnosti, Međimurje, Čakovec, 29. 7. 1964.

78 Navodno je upravo krznar Gašpar Ujlaki u Parizu sašio dolamu i francuskom kralju Luju Bonaparteu III. Nasljedstvo nakon smrti Gašpara Ujlakija iznosilo je čak 70.000 zlatnih franaka, od čega je rodbina Jeronima Ujlakija u ruke dobila tek 70 zlatnih franaka. $\mathrm{O}$ tomu se vodio i veliki sudski spor, ali je otišao u zastaru. Dragutin Em. ŠAFAR, Donja Dubrava između dva rata, o.c., 23-25.

79 Slaven UJLAKI, Donjodubravski plemenitaši - obitelj Hirschler-Zalan, Donjomeđimurski zbornik, 3, Meridijani, Prelog, 2016., 104-105; Dragutin FELETAR, Hrvoje PETRIĆ, i dr., Općina i župa Donja Dubrava, o.c., 102-103.

80 Tu je još bio i sin Antun Hirschler (1843. - 1888,), koji se uglavnom nije uključivao u poslove i umro je relativno mlad. 


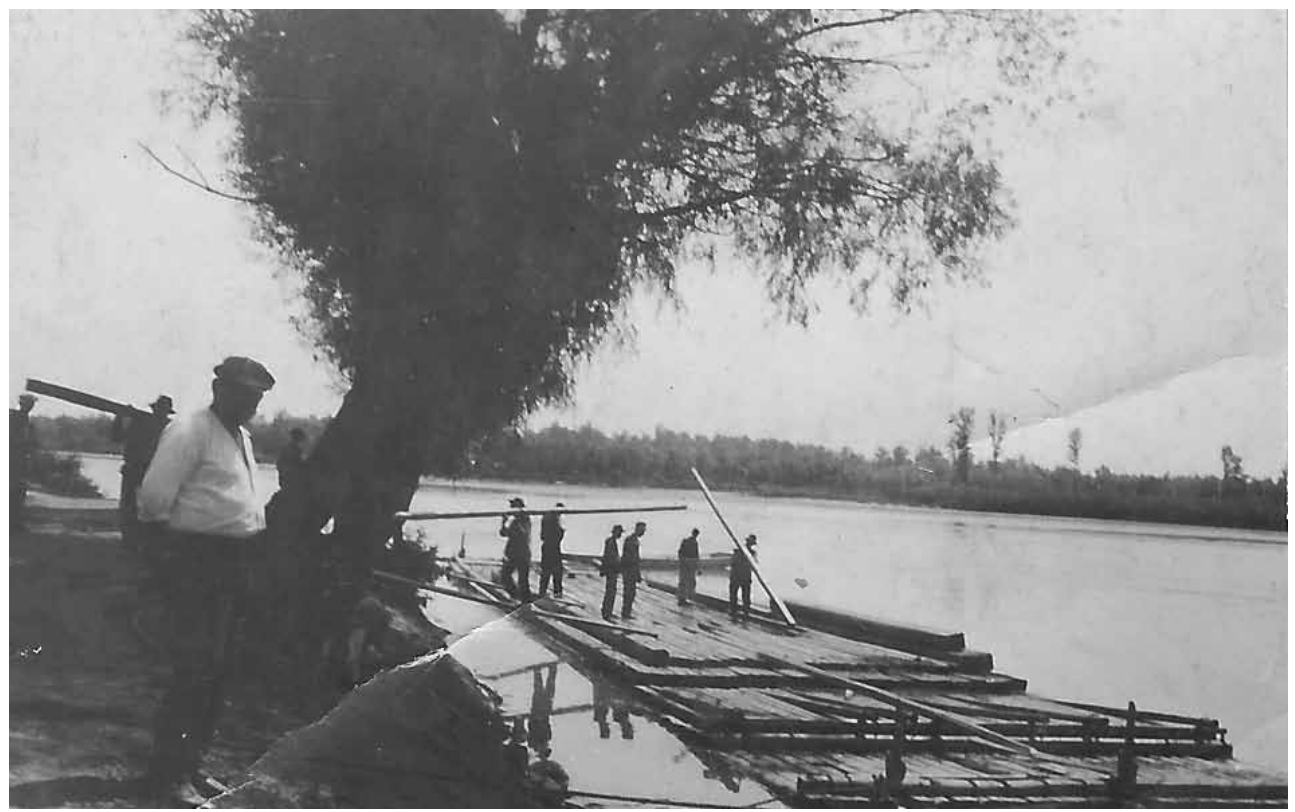

Slika 16. Drvna građa odnosi se sa splavi i na obali se slažu "kašte“ - snimljeno 1932. godine (foto-arhiv D. Feletara)

Zalani imali su brojnu djecu i unuke, od kojih su neki dosegli i zvanje doktora znanosti, te bili i poslanici u mađarskom parlamentu u Budimpešti. ${ }^{81}$

Julius Hirschler sa sinovima prvih se desetljeća djelovanja tvrtke bavio i prodajom (i veleprodajom) razne merkantilne robe, ali sa sve većom dominacijom prometa drvom i drvnom građom. Dobar dio te građe dolazio je splavima (fljojsima) Dravom iz Slovenije, ali se prometovalo i drvom posječenim u Međimurju i Podravini. U to vrijeme bogate pridravske i primurske šume (uglavnom hrasta lužnjaka) počinje masovno sjeći i rasprodavati i vlastelinstvo grofova Feštetića, koje je zapalo u poslovne poteškoće, pogotovo nakon ukidanja kmetstva sredinom 19. stoljeća. Dobar dio toga etata kupuju Hirschleri, pa su postali i vlasnici dijela šumskih parcela. Dio te drvne građe foringaši voze na stovarište u Čakovcu, Koprivnici i Velikoj Kanjiži, a dio se doprema u Donju Dubravu, slaže na splavi i prodaje nizvodno Dravom i Dunavom. ${ }^{82}$

Poslovi tvrtke osobito su se proširili u drugoj polovici 19. stoljeća, kada je njome (uglavnom) upravljao vrlo poduzetni Jakob Hirschler (s braćom Maksom

\footnotetext{
81 Slaven UJLAKI, Donjodubravski plemenitaši.., o.c., 106-110; Dragutin Em. ŠAFAR, Donja Dubrava između dva rata, o.c., 21-30. 


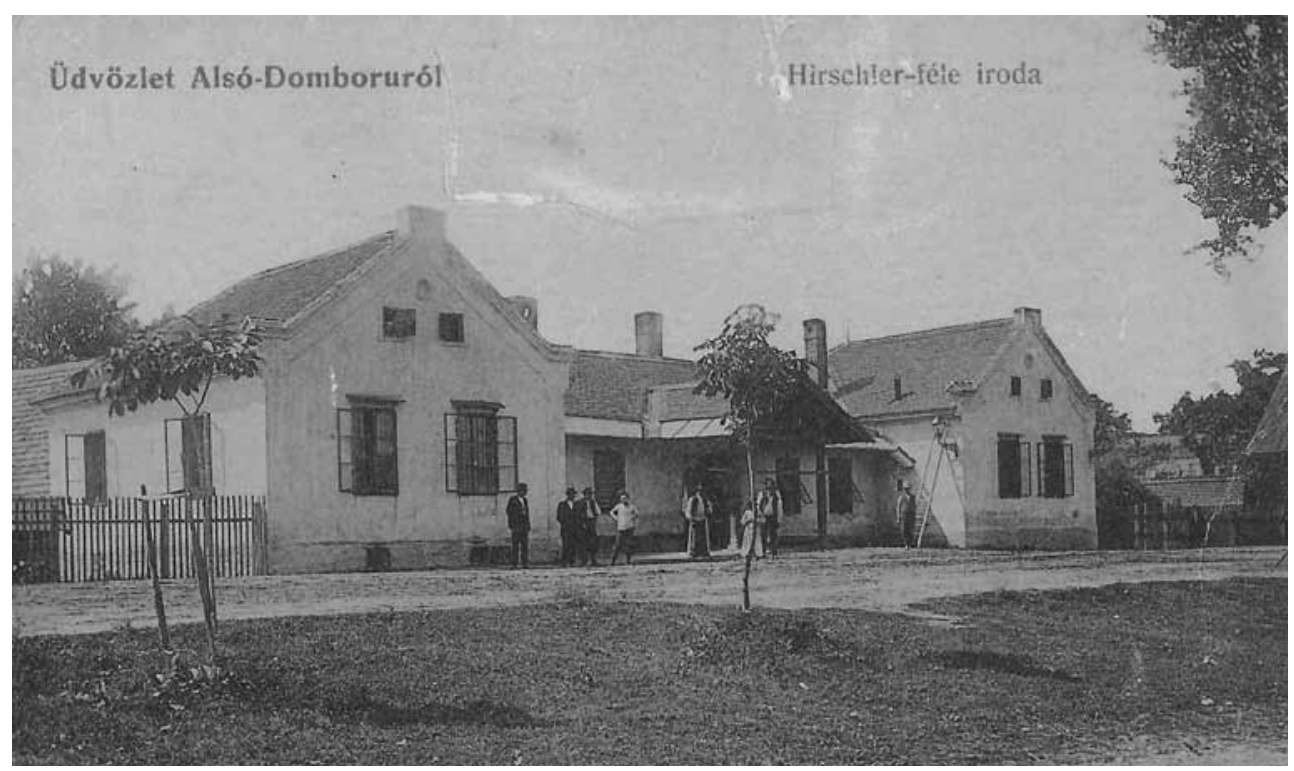

Slika 17. Glavna poslovna zgrada tvrtke Ujlaki-Hirschler blizu dravske lente, izgrađena 1870-ih godina (foto-arhiv D. Feletara)

i Leopoldom). Tome su pogodovale i povoljne okolnosti - ponajprije veliki novi kapital koji je tvrtka dobila iz nasljedstva Gašpara Ujlakija te mirazom bogate Jakobove supruge Adele, ali i znatno povoljniji upravno-porezni uvjeti poslovanja koje je forsirala tržišno orijentirana carska vlast. K tomu treba pribrojiti i nove prometne okolnosti koje su nastupile razmjerno ranim širenjem makadamske mreže cesta i željeznica u ovom dijelu Ugarske, Slovenije i Hrvatske. Naime, 1860. je izgrađena željeznička veza Budimpešte preko Kotoribe i Čakovca prema Pragerskom (i Trstu), a 1870. puštena je u promet i željeznica od Botova prema Zagrebu. Poslovni Hirschleri i tu su prometnu situaciju okrenuli u svoju korist. Oni su jeftini prijevoz drva Dravom funkcionalno povezali s prijevozom foringaša na cestama, a pogotovo sa željeznicom. S lente u Donjoj Dubravi foringaši prevoze drvnu građu na željezničku postaju u Kotoribi, koja tako putuje prema Velikoj Kanjiži i drugim ugarskim gradovima, a pogotovo u Budimpeštu, gdje je tvrtka imala predstavništvo. U vezi s takvim kombiniranim prijevozom, Hirschleri grade i brojne pilane kako bi pospješili prodaju te ostvarili veću dobit. ${ }^{83}$

83 Dragutin Em. ŠAFAR, Donja Dubrava između dva rata, o.c., 20-21; Dragutin FELETAR, Zlatari i splavari na Dravi, Podravski zbornik, 23, Koprivnica, 1976., 125-126; Dragutin FELETAR, Iz povijesti Međimurja, Matica hrvatska, Čakovec, 1968., 190-191. 
U kontekstu jačanja kombiniranog prijevoza, Hirschleri 1870-ih grade oveću pilanu blizu obale Drave u Donjoj Dubravi (u dijelu sela koji se naziva Posranec), uz koju se formiralo i prostrano otvoreno skladište drvne građe (složeno na kašte). U blizini se 1869. gradi tada velebna upravno-poslovna zgrada tvrtke (srušena 1960-ih godina), a nedaleko se utvrđuje dravska obala posebnim betonskim kvadrima i uređuje pristanište (lenta) za splavi i šajke. Kada je donjodubravska pilana izgorjela u požaru, gradi se 1882. nova, još veća pilana uz željezničku prugu u Kotoribi (navodno je zapošljavala i više od 200 radnika), koja je radila sve do kraja Drugog svjetskog rata. Ta je lokacija bila još poticajnija za korištenje kombiniranog prijevoza te za opskrbu drvom Budimpešte i mađarskog tržišta. ${ }^{84}$

Neki od sačuvanih dokumenata (kojih je malo, jer je arhiva uglavnom uništena tijekom i nakon Drugog svjetskog rata) upućuju na zaključak da je na donjodubravskoj lenti postojalo i gradilište čamaca i kompi. S obzirom na djelatnost tvrtke, to je normalna diverzifikacija proizvodnog programa. Primjerice, Blaž Magjer navodi da je „općina novigradska (Novigrad Podravski) naručila u travnju 1882. kod trgovine daskom Ujlaki-Hirschler i sin u Dubravi na Dravi dva čamca, svaki čamac za 25 osoba, za iznos od 32 for. Čamce su dva izaslanika općine Dravom odmah dopremila do Novigradskoga prevoza (broda) i predali tamošnjem brodaru. Jednako je općina dvije godine prije (1880.) kod iste tvrtke kupila dva čamca uz cijenu od 24 for. S kupnjom je bila zadovoljna. ${ }^{\prime 85} \mathrm{U}$ tom pogledu, a pogotovo u nabavi drvne građe, Hirschleri su godinama poslovali i s gradom Koprivnicom te gotovo svim podravskim općinama, a građu su foringaši dopremali izravno s lente u Donjoj Dubravi ili lente na Šancu u Legradu.

I dobivanje obiteljske grbovnice (i plemenitaškog naziva), koju je obitelj Hirschler zadobila 1887. godine, vezano je za njihov plovni park. Naime, tvrtka se prigodom velikih poplava Mure i Drave vrlo predano uključivala u spašavanje ljudi i dobara. Tako je bilo 1878., kada se razlila Mura, te 1882., kada je Drava poplavila obale. O tome svjedoči Ivan Vučenik iz Donje Dubrave, dugogodišnji službenik u upravi Hirschlerove tvrtke: „Kada se Mura (1878.) jako razlila i poplavila nekoliko naselja, za spašavanje ljudi imovine u Podturnu i Kotoribi Hirschleri su dali 70 čamaca koje su imali u Donjoj Dubravi. Taj njihov humani gest su njihovi ljudi u Budimpešti naveliko reklamirali u parlamentu i lokalnoj vladi (Antun, Maks i njegov šurjak Franc Löke su radili u ministarstvu u Budimpešti). Bio je dvoru u Beč podnijet zahtjev da se dobročinitelji nekako nagrade. Jakob Hirschler je sa

\footnotetext{
84 Dragutin FELETAR, Hrvoje PETRIĆ i dr., Općina i župa Donja Dubrava, o.c., 101-105; Slaven UJLAKI, Donjodubravski plemenitaši.., o.c., 107-108.

85 Blaž MAGJER, Časti i dobri zavičaja (Novigrad Podravski), Zagreb, 1937., 179-180; Dragutin FELETAR, ur., Općina Novigrad Podravski, izabrane teme, Novigrad Podravski, 2001., 60-70.
} 


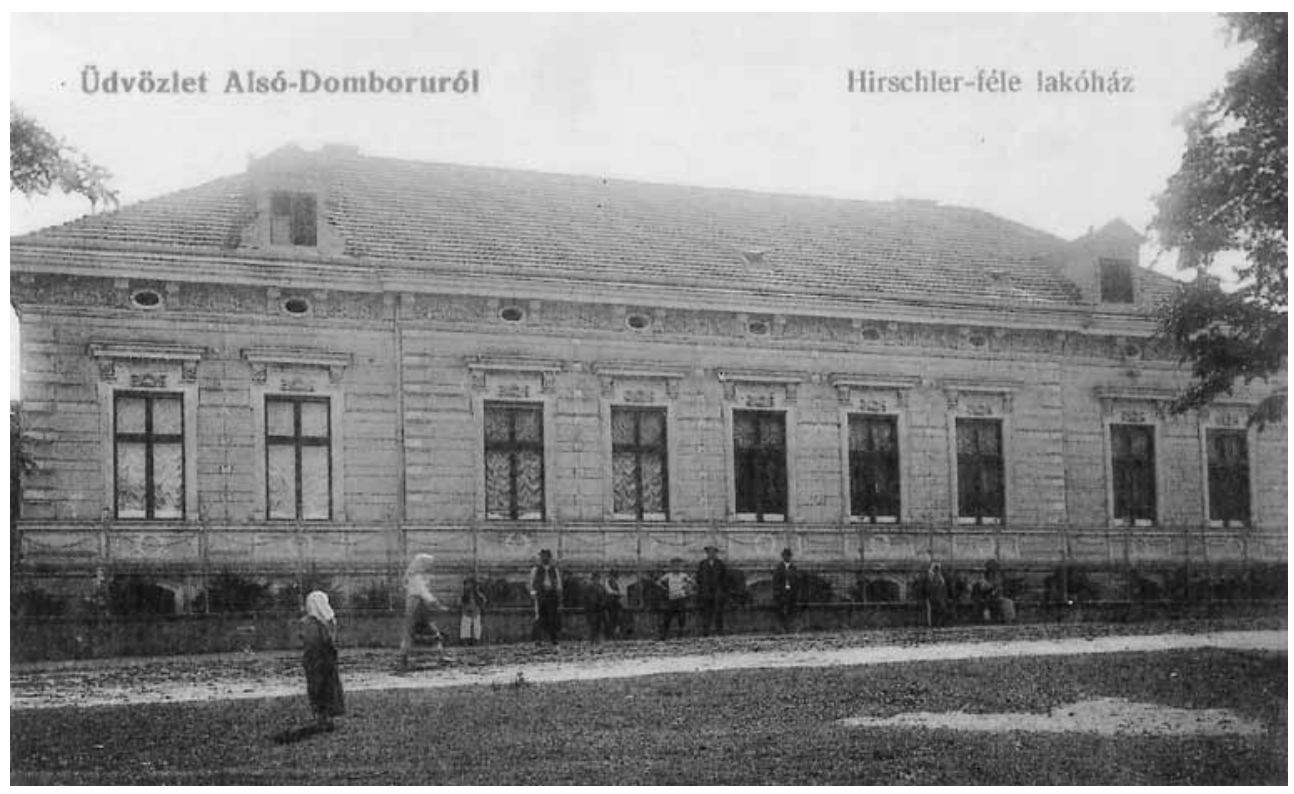

Slika 18. Glavna obiteljska kuća Hirschler u središtu Donje Dubrave (foto-arhiv D. Feletara)

starim ocem Juliusom otišao u Beč na službenu audijenciju kod cara Franje Josipa. Na pitanje cara što želi, čime da ga nagradi za njegov humani čin spašavanja njegovih podanika, Julius Hirschler se zahvalio caru kada je predlagao da mu da novac ili posjed. Drhtavim glasom je izjavio da bi želio plemstvo za obitelj, jer sve drugo ima. ${ }^{\prime 86}$ Tako su 1887. Hirschleri dobili obiteljsku grbovnicu, a ukaz je donijela Ugarska carska kancelarija. ${ }^{87}$ Zbog nesebičnog pomaganja vojnicima na početku Prvog svjetskoga rata (pa i zbog organizacije vojne ranarnice u Donjoj Dubravi), Hirschleri su 1917. dobili (dijelom kupili) i titulu baruna. ${ }^{88}$

Za brojne slovenske splavare (flosare) Donja Dubrava bila je uglavnom zadnja postaja ili se pak mijenjao dio posade. Naime, na donjodubravskoj lenti razlagale su se po dimenzijama nešto manje splavi, te su se ponovno formirala znatno veća plovila, jer je nizvodno tok Drave bio mnogo mirniji. Time su se troškovi plovidbe po kubiku drva još i smanjili. Te veće splavi obično su vozili du-

86 Zabilježio Dragutin Em. ŠAFAR (Donja Dubrava između sva rata, o.c., 23).

87 Grb obitelji Hirschler sačuvan je do danas, a na grbovnici su zabilježena imena: Maks, Antun, Ciprat Janos, Jakob, Henrik, Odeon, Toni Hirschler, te djeca Lipota Janosa - Istvan, Gyula, Pall, Ferencz, György, Resszo, Margit i Ilona. Slaven UJLAKI, Donjodubravski plemenitaši.., o.c., 107.

88 Prema izjavi Ivana Vučenika, službenika kod Hirschlera. Pribilježio 1967. Dragutin Feletar. Dragutin FELETAR, Hrvoje PETRIĆ i dr., Općina i župa Donja Dubrava, o.c., 103. 

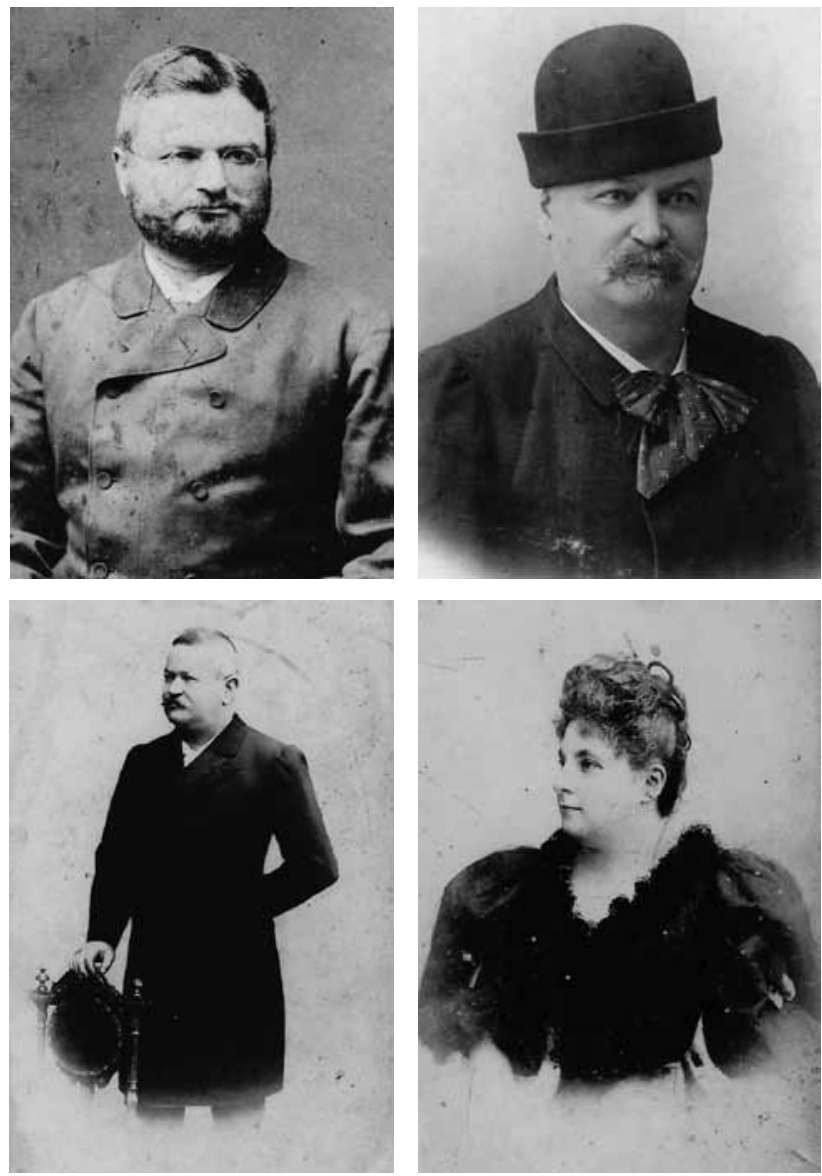

Slika 19. Glavni vlasnici i voditelji tvrtke Ujlaki-Hirschler i sin iz Donje Dubrave: Jakob Hirschler, Leopold HirschlerZalan, Maksimilijan Hirschler i Adela Hirschler (album iz Osnovne škole D. Dubrava) bravski fliojsari (splavari), iako je u posadama znalo biti i podosta Slovenaca. Slovenski kormanuši boravili bi koji dan u nekoj od brojnih seoskih krčmi (od kojih je najpoznatija bila Rusača - krčma i prenočište obitelji Rusak), te su se potom željeznicom ili drugim prijevozom vraćali u Duplek, Ožbalt, Podvelku ili Vuzenicu i Dravograd. Tako je, zapravo, tvrtka UjlakiHirschler i sin veći dio svojih potreba za drvnom građom osiguravala od slovenskih (i austrijskih) trgovaca, ali dio splavi formiran je i od drvne građe koja je posječena sa šumskih revira koji su bili vlasništvo dubravske firme. Promet splavi bio je sve do Drugog svjetskog rata vrlo intenzivan, a veći dio te drvne građe prodan je nizvodno Dravom i Dunavom ili odve-

zen željeznicom u ugarske i hrvatske gradove u organizaciji donjodubravskog poduzeća. Kao što smo već naveli, računa se da je početkom 19. stoljeća Dravom godimice plovilo oko 200 splavi, potkraj toga stoljeća čak do 2.000 takvih plovila, da bi kroz prevodnicu na HE Fala 1922. prošle 684 splavi, a 1938. godine čak 1.266 fljojsa. Većina te goleme drvne građe prošla je i Donju Dubravu.

Osim što su pokupovali dio Feštetićevih šumskih parcela u Međimurju, Hirschleri su sustavno kupovali sve veće komplekse šuma na Pohorju i Kobanskom (Kozjaku), a kasnije i u Prekomurju, jugozapadnoj Ugarskoj, pa čak i u središnjoj Bosni (Pale kod Sarajeva). Znatne šumske revire dubravska tvrtka imala 
je oko Dravograda te istočno od Lendave. „Tvrtka je za svoje potrebe 1913. izgradila i uskotračnu šumsku željeznicu u dužini od $33 \mathrm{~km}$, koja je išla od Rediča do Szilvagyija u jugozapadnoj Mađarskoj“ ${ }^{19}$ Zbog posjeda u Prekomurju, Hirschleri su imali i sudske sporove. „Tako u Savezu šumarskih društava Slovenije piše da je šumsko veleposjedstvo u Košenjaku uz austrijsku granicu godine 1890. bilo u vlasništvu firme Ujlaki-Hirschler. Slovenski list „Korošec“ 9. rujna 1920. piše da Hirschleri imaju problema sa slovenskim vlastima oko eksploatacije šuma na Kobilju u Prekomurju. Naime, 1912. firma je sklopila ugovor s veleposjednikom Miklosom Esterhazyijem o eksploataciji šume u Kobilju. ${ }^{.90}$

Do početka 20. stoljeća tvrtka Ujlaki-Hirschler i sin poslovala je na velikom prostoru od Dravograda na zapadu do Smedereva na istoku te od Budimpešte na sjeveru do Pala (Sarajeva) na jugu. Samostalno ili u partnerstvu tvrtka je imala svoje pilane i poslovna predstavništva (i skladišta) u Dravogradu, Ožbaltu i Mariboru, Zagrebu, Koprivnici, Čakovcu, Osijeku i Sarajevu, u Budimpešti, Rediču, Velikoj Kanjiži i Zalaegerszegu te u Novom Sadu, Bečeju, Beogradu, Smederevu i drugdje. „Na pilane je stotine zaprega dovozilo trupce iz okolnih šuma, kao i piljenu građu sa splavi prevozilo s dubravske lente u Kotoribu na utovar u vagone. Već 1908. godine, kada se slavila 80-godišnjica tvrtke, Hirschleri su imali 16 velikih pilana diljem Austro-Ugarskog imperija (Dornbirn, Kirschbach, Bruck an dem Mur, Dravograd, Kotoriba, u Galiciji, Erdelju, Slavoniji pa i u Bosni). Tada se njihov aktivni kapital procjenjivao na visokih 36 milijuna zlatnih kruna. ${ }^{.91}$ Kolika je bila snaga dubravske tvrtke, govori i podatak iz 1914. godine, kada je Maximilijan (Mikša, Maks) Hirschler platio 3.260,40 forinti poreza, što je bilo među najvišima u Županiji Zala - u Međimurju je nešto više platilo samo vlastelinstvo grofova Feštetić. ${ }^{2}$ Računa se da je u svim pogonima i poslovnim jedinicama tvrtke Ujlaki-Hirschler 1925. godine radilo između 400 i 500 radnika. Samo u Donjoj Dubravi u firmi je bilo stalno zaposleno od 60 do 80 splavara, zatim 22 činovnika, 6 organizatora ili poslovođa (šafara) te nekoliko desetaka sezonskih randika. U pilani u Kotoribi u špici je radilo i po 200 radnika, a bio je angažiran i velik broj foringaša (prijevoznika). U pilanama ili predstavništvima u Dravogradu radilo je oko 40 radnika, u Budimpešti 36, na Palama 40, Mariboru

\footnotetext{
89 Slaven UJLAKI, Donjodubravski plemenitaši.., o.c., 108-109.

90 Miroslav KUKOLJ, Prekomurski Slovenci od narodne osvoditve do nacističke okupacije, 1919.-1941., Murska Sobota, 1984., 524-526; Slaven UJLAKI, Donjodubravski plemenitaši.., o.c., 108-110; Dragutin FELETAR, Hrvoje PETRIĆ i dr. Općina i župa Donja Dubrava, o.c., 109. 


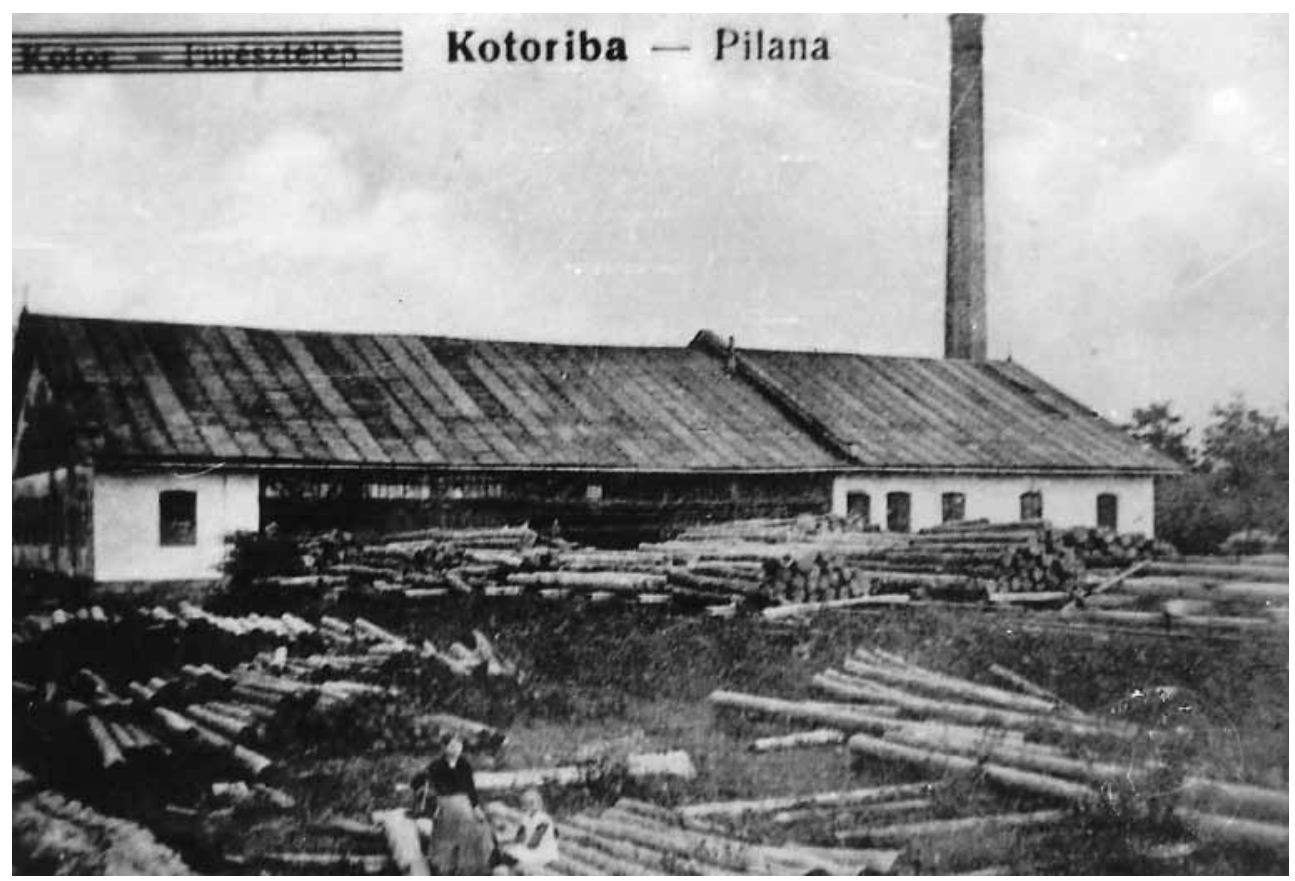

Slika 20. Pilana tvrtke Ujlaki-Hirschler i sin kod željezničke pruge u Kotoribi - snimljena početkom 20. stoljeća (foto-arhiv D. Feletara)

oko 20 itd. ${ }^{33}$ Od prometa tvrtke živi velik broj dubravskih trgovina, a posebice krčmi i prenoćišta. Naselje se razmjerno brzo urbanistički širi, uz znatan porast broja stanovnika: godine 1857. u Donjoj Dubravi živjela su 2.602 žitelja, da bi taj broj porastao do 1910. na 3.734 duše ili za oko 40 posto. ${ }^{94}$

Nakon velebne proslave 80 . godišnjice osnivanja tvrtke Ujlaki-Hirschler i sin 1908. godine, opći uvjeti poslovanja, ali i prilike u obitelji, bitno su se promijenili. Veliki rat 1914. - 1918. osiromašio je i donjodubravske veletrgovce, a 1918. promijenjene su i državne granice. Time je uglavnom izgubljeno veliko mađarsko tržište, iako se još nešto drvne građe isporučivalo željeznicom iz Kotoribe prema Budimpešti. Uz to, Drava je uglavnom postala granična rijeka, što je znatno otežalo organizaciju plovidbe, uz rast troškova. Na suženom jugoslavenskom tržištu ojačala je i konkurencija, jer su ojačali veletrgovci drvom prvenstveno iz Slo-

\footnotetext{
93 Prema kazivanju tada još živih splavara i službenika kod Hirschlera, pribilježio Dragutin Feletar 1967. godine. Dragutin FELETAR, Iz povijesti Međimurja, Čakovec, 1968., 190.

94 Popisi stanovništva 1857. i 1910. godine, Državni zavod za statistiku, Zagreb.
} 
venije (iz pridravskih mjesta), ali i iz Podunavlja (primjerice, Steineri iz Vukovara i drugi). I u samoj Donjoj Dubravi javljaju se i druge tvrtke koje su trgovale drvnom građom, a vlasnici su „ispekli“ zanat kod Hirschlera.

I prilike u samoj obitelji Hirschler su se pogoršale. Godine 1919. umire poduzetni Maks Hirschler, pa njegova udovica Adela vodi poslove zajedno sa sinom Rudolfom, dok su se ostala djeca i unuci raselili po svijetu ili su živjeli od apanaže. Dragutin Šafar slikovito opisuje stanje u obitelji Hirschler, kao da su slični Krležinim Glembajevima: „Degenerirani i bez menadžerskog talenta, sinovi Jakoba za jednu deceniju raspršili su bogatstva koja su im preci stekli. U tome im je pomogla i raspuštena majka Adela, koja je vodila „slatki život" po ljetovalištima Europe više od dvadeset godina (..). Svi ti pravnici, glavni računovođe i komercijalisti još u dvadesetim godinama su vjerno služili i ulizivali se "milostivom gospodinu i gospođi Hirschler", da bi već u tridesetim godinama sami postali veletrgovci drvom, vlasnici pilana i kuća Hirschlerovih. Česti lovovi, poslije njih gozbe i piknikovanje, razuzdane zabave, polasci u Zagreb u hotel Esplanade na večere, dva šofera i četiri paradna kočijaša i desetak drugog osoblja posluge - sve je to odnijelo milijune koje su stekli preci. ${ }^{\text {‘95 }}$

Tako je vrlo svečana proslava 100. godišnjice tvrtke 1928. godine bila zapravo labuđi pjev. U danima slavlja na fljojsima na Dravi opet su plamtjele vatre, došli su plemići, političari, poslovni ljudi, crkveni i drugi velikodostojanstvenici iz Hrvatske, Slovenije, Mađarske, Austrije i šire. Slavilo se na Dravi, ali i u palačama u središtu Donje Dubrave. Livrirani kočijaši dočekivali su goste na kolodvo-

$\overline{95}$ Dragutin Em. ŠFAFAR, Donja Dubrava između dva rata, o.c., 24-26. 
rima u Kotoribi i Koprivnici, a seoske snaše posluživale su goste. Bio je upriličen i atraktivan lov u pridravskim šumama. Hirschlerov imperij još nije htio priznati da je pred krahom. Stoljetnu fascinantnu poslovnu plovidbu tvrtke UjlakiHirschler i sin dokrajčila je svjetska ekonomska kriza nakon 1929. godine. ${ }^{96}$

Nelikvidnost i nemogućnost vraćanja dugova (pogotovo bankama) stjerao je tvrtku u stečaj. Godine 1934. firmu preuzima Prva hrvatska štedionica, koja je najveći dio imovine rasprodala. Neke dijelove i poslove pokupovali su i nastavili poslovati domaći poduzetnici, koji su do kraha radili kod Hirschlera. Tako braća Rado preuzimaju veliku pilanu u Kotoribi (koja je radila do kraja Drugog svjetskog rata, kada je srušena), Eugen Kaufmann kupuje dio skladišta na Dravi (zajedno sa Steinerima) te jednu od palača u središtu Donje Dubrave (poslovao je do 1943. godine) itd. ${ }^{97}$ Većina članova obitelji Hirschler stradala je u holokaustu. Uglavnom uz organizaciju slovenskih trgovaca i splavarskih gazdi, fljojsi su do Donje Dubrave i dalje Dravom i Dunavom aktivno plovili sve do samog početka rata 1941. godine, a nakon 1945. splavarstvo se više nije obnovilo (pa i zbog izgradnje brojnih hidroelektrana na Dravi i Muri). ${ }^{98}$

\section{SPLAVI I ŠAJKE - GRADNJA I ZNAČAJKE}

Kroz prošlost na Dravi su se gradile i Dravom su prometale uglavnom četiri vrste drvenih plovila. To je ponajprije čamac (chun, čun, ladja, navis, čon). ${ }^{99}$ Nekad se gradio i od jednoga debla (hrasta lužnjaka, jagnjeda, vrbe), tako da se deblo cijelom dužinom izdubilo posebnom vrstom sjekirke. Inače se gradi od dasaka koje su spojene posebnim drvenim rebrima uz uporabu drvenih klinaca ili ručno izrađenih čavala i klanfi kod kovača. Veći čamci mogli su prevoziti i petnaestak ljudi, a plovilo se na vesla. Kompe (komp, ladja, brod, plav) su zapravo veliki (dugi i široki) čamci koji su se spajali u paru te su povezani širokim drvenim platoom služili za prijevoz stoke i zaprežnih kola (u novije vrijeme i automobila) i „nošenje“" mlinarskoga kola i kućice sa starinskim mlinom (vodenica). ${ }^{100}$

\footnotetext{
96 Dragutin FELETAR, Hrvoje PETRIĆ i dr., Općina i župa Donja Dubrava, o.c., 113-115.

Tvrtka koja je u Kotoribi kupila Hirschlerovu pilanu zvala se „Pilana braće Rado“, Kaufmannova tvrtka u Donjoj Dubravi „Borka“, a skladište i veletrgovinu drvom na Dravi u Donjoj Dubravi imala je tvrtka „Braća Steiner“. Dragutin Em. ŠAFAR, „Dolnja rajža“-Vukovar-Bata, Dobravske novine, Općina Donja Dubrava, 25. 12. 2008.

Dragutin Feletar, Iz povijesti Međimurja, o.c., 189-192.

Belostenec piše: chun, ladja, plav, a mose biti ribichki chun, velika za velke terhe, pa kojasze z veszli vozi, za prevezenye prek vod potochneh. Joanis Bellosztenecz, Gazophylacium, Zagrabie, 1740., 54, 193, 194. Naziv čamca ili čuna nije kajkaviziran (kroatiziran) iz njemačkog jezika (der Kahn, das Boot, das Ruderboot - čamac na vesla).

100 Za Belostenca kompa je isto što i brod ili ladja. To je plovilo na kojesze chez vodu prehagya. Brodar
} 


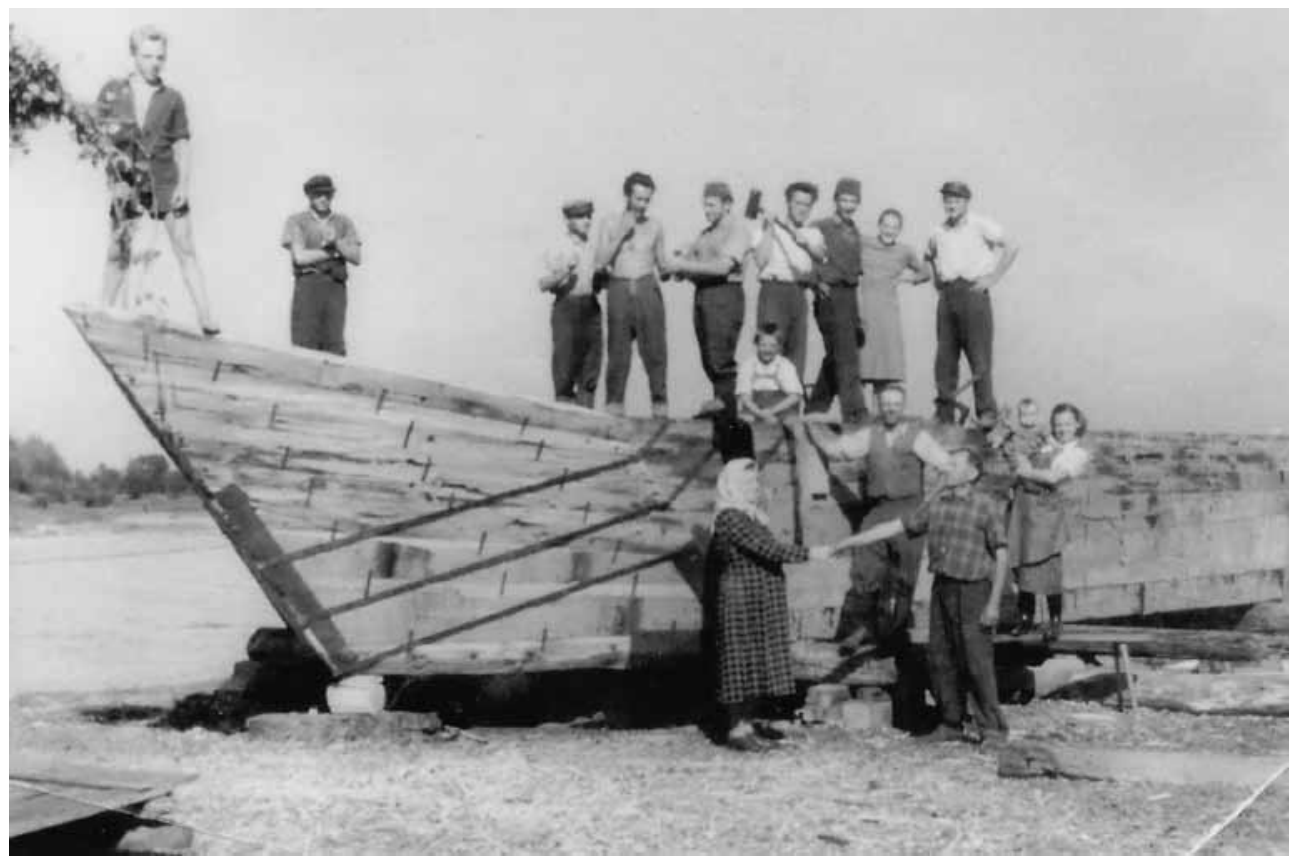

Slika 22. Izgradnja kompe za potrebe postavljanja vodenice kod Novog Virja 1950-ih godina (arhiv Z. Ištvana)

Kompama se i plovilo Dravom te se prevozila merkantilna roba (osobito sol), a ponegdje su kao samostalna plovila služile za prijevoz ljudi i stoke s jedne na drugu obalu. Nekad su se kompe gradile u Legradu i Donjoj Dubravi, a kasnije uz obalu kod Novoga Virja i drugdje.

Šajka je veće (kombinirano) plovilo koje u osnovi ima: ili plitku kompu ili duplo povezanu oblovinu. Na prostranom drvenom podu šajke obično je napravljena drvena kućica za čuvanje robe (i šajkaša) i tijekom vožnje. To su zapravo bile male riječne trgovine (s merkantilnom i drugom robom), ali se često prevozila i drvna građa. Veliki rječnik hrvatskog standardnog jezika šajku tumači kao drveni ratni brod s Dunava 11. - 18. stoljeća (šajke su bile i čuvari granice prema Osmanskom Carstvu) ili kao čamac ratne mornarice na $1-2$ para vesala ili pak

- koji vu chunu ali ladje prevasa. Brod ili kompa je plovilo na kesze konyi prevasaju, ili: koja ima veszla na chetiri rede, ili: na kojesse sitek vozi, ili: $z$ jednoga falata derva zdelana (veliki čamac). Joanis Bellosztenecz, Gazophylacium, o.c., 31, 193-194. Kormanuš, kormilar ili kormanik (Dumenar, Gubernator, navis) je „on koi na klyunu broda sztoi“. Bellosztenecz, o.c., 175. 
kao mali jedrenjak na Levantu. ${ }^{101}$ Belostenec za hrvatsku kajkavsku riječ sayka kao objašnjenje navodi latinske riječi: celox, biremis, lembus ili myoparo. ${ }^{102}$

Splav (szplav, floss, fljojs, flosar, fljojsar) specijalizirano je plovilo za prijevoz drvne građe i galanterije (na Dravi ili kojoj drugoj rijeci). Belostenec ne navodi posebno riječ splav (szplav) već tada uporabnu hrvatsku kajkavsku riječ fljos: flyosz je därveni szlog, povodnica därvena, drevo szkloplyeno zverhu vode. ${ }^{103}$ Flos, fljojs, flosari, fljojsari zapravo su kajkavizirane njemačke riječi: das Floss, der Flösser (splavar), die Flösserei (splavarstvo), flössen (splavariti). ${ }^{104} \mathrm{Uz}$ šajku i splav vezana je i slovenska riječ ranca, što znači lagani čamac ili čon. Fljosari su uz splav obvezno vezali jedan ili dva čona ili rance, prvenstveno radi spašavanja u slučaju opasnosti ili odlazaka na obalu po hranu, piće ili dodatnu opremu. ${ }^{105}$

1. Šajke. Osim splavi (fljojsi) kao osnovnog prijevoznog sredstva za drvo, za razvoj dravskog splavarstva važnu ulogu imalo je šajkaštvo, odnosno izrada šajki. Vrlo često, pogotovo do kraja 19. stoljeća, drvo (pogotovo piljena ili žagana drvna građa) Dravom se prevozilo upravo šajkama, iako su one bile prvenstveno namijenjene prijevozu merkantilne i slične robe. Šajka je primitivna lađa ili kompa, koja je obično bila duga 13 - 14 m (oko 7 sežnjev), široka oko 6 - 7 m (3 do 4 sežnjev) te duboka ili visoka oko $1 \mathrm{~m}\left(39\right.$ - 40 palaca). ${ }^{106}$

Izrada dobre šajke bila je pravi tesarski pothvat, a najbolji meštri za gradnju šajki bili su prvenstveno iz Vuzenice, pa i iz Vuhreda, Dravograda, Libeliča, Dupleka, Legrada i Donje Dubrave. Najprije je trebalo pripraviti građu za dno i stranice šajke. Glavni dijelovi te građe bili su: pet pari klupa, zatim pet pari špangi te dva velika (7 klaftri duga) i dva mala (3 klaftra) cajšpana. Klupa se izrađivala od ravnog smrekova drva (debelog oko 6 cola ili $14-16 \mathrm{~cm}$ ), koje je imalo debeli korijen nagnut na deblo oko 100 stupnjeva. Klupe su bile duge oko 11,5 m

$\overline{101}$ Ljiljana Jajić, ur., Veliki rječnik hrvatskog standardnog jezika, Školska knjiga, Zagreb, 2015., 1509.

Joanis Bellosztenecz, o.c., 475; Latinska riječ myoporo znači lagani brod za gusarenje, celox je vrsta laganog brzog broda, biremis je čamac na dva vesla, a lembus je mala brodica, barka, hitri čamac, brza brodica ili malena brzoplovka. Jozo Marević, Latinsko-hrvatski enciklopedijski rječnik, Matica hrvatska, Zagreb, 2000., 331, 1741, 1997.

103 Flosar, fljojsar (flyòszar) je plutvar ili ratiarius (što latinski znači proizvođač ili prodavatelj splavi ili onaj što plovi na splavi). Bellosztenecz, o.c., II./97; Marević, Latinsko-hrvatski enciklopedijski rječnik, o.c., 2627.

104 Blanka Jakić, Antun Hurm, Hrvatsko-njemački rječnik, Školska knjiga, Zagreb, 1991., 978.

105 Prema ranci ili čamcu (čunu) 1960-ih i 1970-ih zvale su se turističke manifestacije plovidbe Dravom od Beljaka, Maribora do Donje Dubrave i Barča - rancarija. Organizator je u pravilu bio mariborski dnevnik Večer.

106 Starinske mjere koje su rabili šajkaši i splavari došle su u Hrvatsku uglavnom iz Štajerske (Slovenije). Tako 1 dunajski (bečki) palac ili col iznosi 26,4 mm, 1 sežanj klaftra 189,65 cm, 1 lakat 77,76 cm, a vrijednost se mjerila u fl. Ili goldinar-rajniš (1960-tih je to preračunato vrijedilo 1.000 dinara). Franjo Pahernik, Šajke in splavi na Dravi, o.c., 3. 


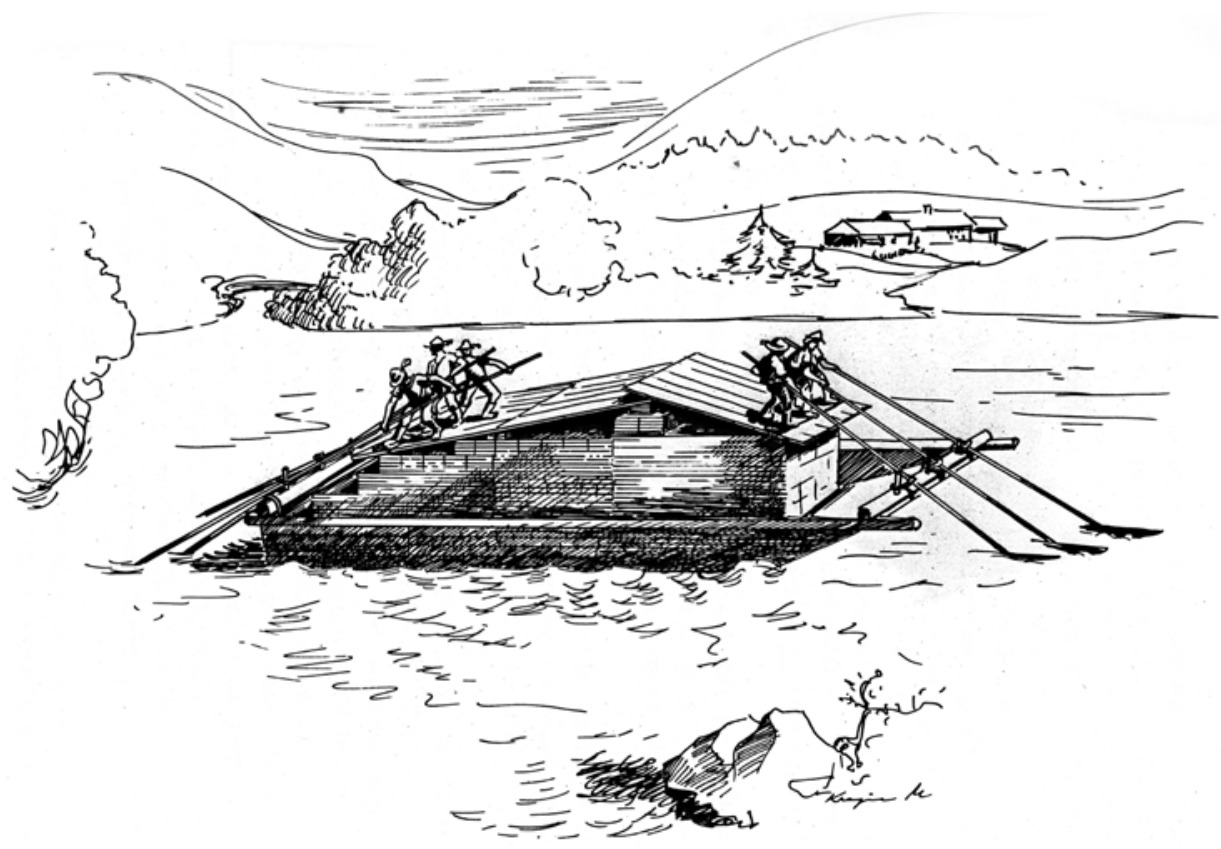

Slika 23. Plovidba šajke po Dravi u Sloveniji - vodi je 6 splavara, a natovarena je drvnom građom (Franjo Pahernik, 1962.)

i povezivale su dno i stranice šajke. Poprečno na klupe stavljalo se 5 pari špangi, koje su bile debljine oko $10 \mathrm{~cm}$, a duge oko 5,7 m (3 sežnja). Špange su na kraju imale pribijenee drvene špice dužine oko $1 \mathrm{~m}$, koje su činile podaščane stranice šajke. Klupe i špange pribijale su se drvenim klincima cvekima). Na tu konstrukciju pribijale su se daske, obično debljine oko $4 \mathrm{~cm}$. Cijelu šajku povezivala su 4 cajšpana. Dva su bila duga $14 \mathrm{~m}$ (i debela 12 cola ili oko $30 \mathrm{~cm}$ ), a dva dužine $6 \mathrm{~m}$. Cajšpani su se učvršćivali na šajku dijelom čavlima (cvekima) izrađenim ručno u kovačnici ili klincima od topolova drva (u Koruškoj su se zvali bolhe). ${ }^{107}$

Na šajki je bilo potrebno za upravljanje najmanje 6 vesala (šajkaši su ih zvali lemezi, a nizvodno u Hrvatskoj veslo). Obično su se vesla izrađivala iz probranoga drva lijeske, breze ili graba, a bila su duga oko $7 \mathrm{~m}$. Vrh ili pero vesla, koje je bilo plosnato oblikovano, bilo je dugo gotovo $2 \mathrm{~m}$, a debelo od oko $1 \mathrm{col}$ na vrhu do 8 cola. Od obveznog pribora bila je važna i posebna drvena lopata, koja se obič-

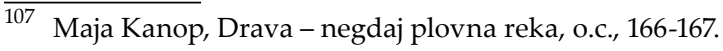


no tesala iz jednog komada bukovine. Lopata je bila duga oko $40 \mathrm{~cm}$, duboka do $8 \mathrm{~cm}$, a široka oko $23 \mathrm{~cm}$ - na nju se nadovezivao držač obično u dužini od $40 \mathrm{~cm}$. Ta se lopata koristila za povremeno izbacivanje vode s dna šajke, jer daske nikad nisu mogle biti tako besprijekorno spojene da se ne bi nakupljala voda (baš kao i u dravskome čonu). Šajkaši su uvijek sa sobom nosili i gotovo sve alate potrebne za izradu šajki, pogotovo ako se išlo na dulju plovidbu, kako bi šajku popravljali i učvršćivali tijekom plovidbe. ${ }^{108}$ Šajkom je na vodi upravljalo 6 šajkaša - po tri vesla naprijed i otraga, a plovidbom je ravnao glavni šajkaš ili kormanoš.

Na šajki je u pravilu bio izgrađen krov od jelovih ili smrekovih dasaka (debljine oko 1 cola). Krov na dvije vode služio je za zaštitu drvne građe, ali i šajkaša. Ako se vozila merkantilna roba, onda je na šajki izgrađena prava drvena kućica - bile su to zapravo pokretne dravske trgovine. U Vuzenici ili drugdje na Dravi šajku je obično gradilo 8 muškaraca, a ako su bili dobro uvježbani te ako je bio unaprijed pripremljen sav potreban materijal, oni su mogli u dva dana izgraditi tri šajke (za izradu jedne šajke obično su u drugoj polovici 19. stoljeća bivali plaćeni $10 \mathrm{fl}$.). Ako se na šajki vozila drvna građa, onda je to bilo u pravilu piljeno (žagano) drvo, odnosno daske, grede, letve i drvna galanterija. Pahernik navodi da je jedna prosječna šajka mogla nositi oko $60 \mathrm{~m}^{3}$ piljene građe, a trebalo je 6 momaka da jedan dan natovari šajku drvnom građom. Također spominje da se najviše šajki „nakladalo v pristaniščih Meža pri Dravogradu, Vuzenica, Vuhred, Brezno, manjše pa na Fali, Smolniku pri Rušah in v Selnici“, a najviše transporta šajki prodalo se u Donjoj Dubravi trgovačkoj firmi Ujlaki-Hirschler i sin. ${ }^{109}$

2. Splav. Na hrvatskom potezu Drave od šajkaštva znatno je važnije bilo splavarstvo (fljojsarstvo), odnosno gradnja splavi (fljojsi). Splavi su se gradile u većini pristaništa na emitivnom području uz Dravu - od Libeliča do Dupleka, ali uvelike i u poslovnom središtu splavarstva, međimurskoj Donjoj Dubravi. Tu su u pravilu manje splavi koje su doplovile iz Slovenije spajali u veće ili pak rastavljali na dobravskoj lenti te sastavljali veće fljojse, jer je nizvodno Drava bila mirnija rijeka (a pogotovo nizvodni Dunav). ${ }^{110}$

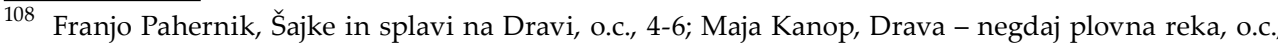
167-178. Gradnja šajki i splavi utjecala je na brži razvoj niza obrta u mjestima na Dravi. Primjerice, u Donjoj Dubravi krajem 18. i početkom 19. stoljeća djelovalo je nekoliko cehova. U mjestu je u 19. stoljeću bilo registrirano i 9 kovačkih i 19 stolarskih radionica, a radilo je i nekoliko užara, draksara i sličnih struka, koji su radili i za splavare. Dragutin Feletar, Hrvoje Petrić i dr., Općina i župa Donja Dubrava, o.c., 77-80.

109 Franjo Pahernik, Šajke in splavi na Dravi, o.c., 6-14.

110 Dragutin Feletar, Hrvoje Petrić i dr., Općina i župa Donja Dubrava, o.c., 102-106; Dragutin Šafar, Donja Dubrava između dva svjetska rata, o.c., 21-24; Slaven Ujlaki, Donjodubravski plemenitaši.., o.c., $105-110$ 


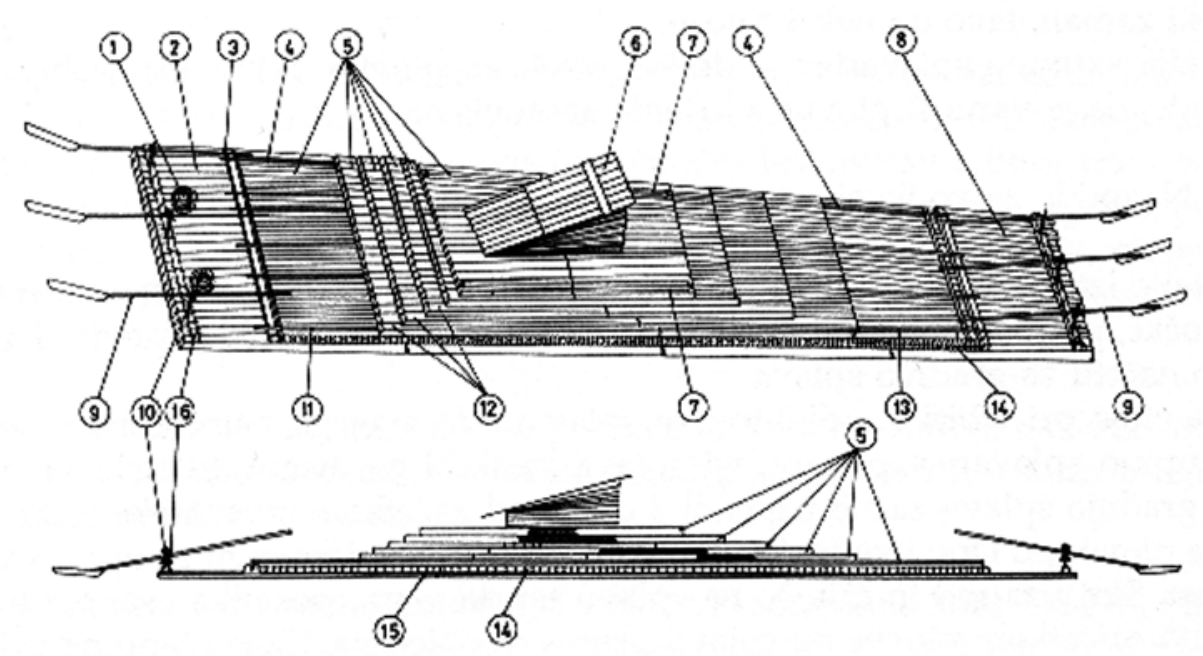

Slika 24. Nacrt splavi iz Splavarskog muzeja u Javniku - ova je dužine 24 m i širine 5 m, a može sadržavati do $50 \mathrm{~m} 3$ drvne građe

Splavi (flosi, fljojsi) posebna su plovila na Dravi (i drugim rijekama) koja su izričito služila za prijevoz drva (lesa). Nizvodno rijekom kupcu se prodao cjelokupni sastav splavi, pa i njegov nosivi dio. Po načinu povezivanja, čvrstini i veličini, pa i obliku, splav se mijenjala kroz povijest, što je zavisilo od razvoja tehnologije. Na panou Splavarskog muzeja (obitelji Šarman) u Javniku kod Ožbalta može se pročitati da se prijevoz drva splavi prvi put spominje 1371. godine (a postojao je vjerojatno i ranije) - to su bile posve primitivne i male splavi, na kojima su balvani bili povezani vrbovim šibama (gožvama). Kroz stoljeća je tehnika gradnje splavi stalno napredovala, a veličina (i količina drvne mase) stalno je rasla. Tako se na potezu Drave od Beljaka do Donje Dubrave od kraja 18. stoljeća uglavnom grade čvršće vezane splavi, koje su mogle izdržati dravske brzace. Te su splavi (koje su u Sloveniji zvali hlodovce) bile duge $16-24 \mathrm{~m}$, a široke u pravilu oko $5 \mathrm{~m}$. U drugoj polovici 19. stoljeća gradile su se još veće splavi uz novu tehnologiju koju su donijeli uglavnom talijanski tesari (pa su te splavi zvali talijanšek). Taj tip „moderne“ splavi bio je dug do $33 \mathrm{~m}$, naprijed širok $6 \mathrm{~m}$, a otraga $5 \mathrm{~m}$. Na čvrsto povezan pod splavi, za što se koristila uglavnom tesana i piljena (žagana) građa, moglo se natovariti i do 120 kubika drvne građe različitih dužina. Tovarenje drvne građe na splav imalo je poseban red i pravila. ${ }^{111}$

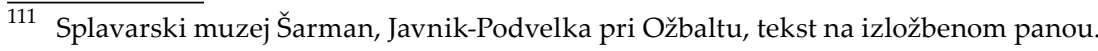




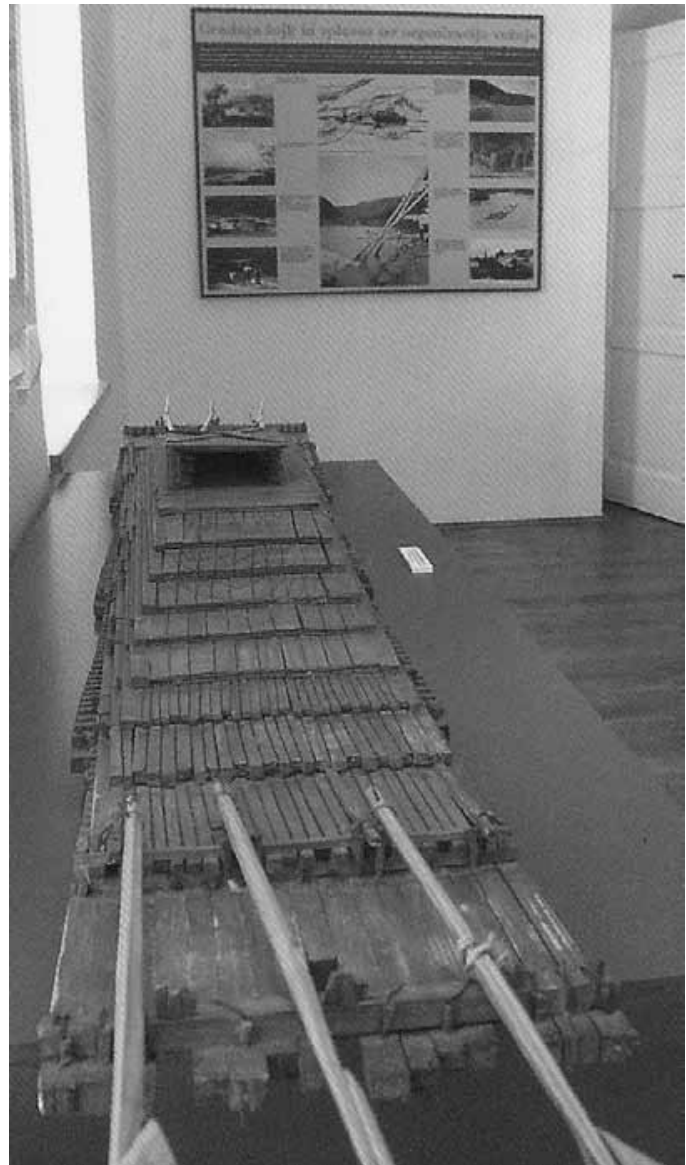

Slika 25. Model manje splavi u Splavarskom muzeju Šarman u Javniku (snimio P. Feletar, 2015.)
U Donjoj Dubravi gradili su i nešto veće splavi kako bi mirnijom Dravom prema Dunavu prevezli što veće količine drvne građe. ${ }^{112}$

Splav je gradila iskusna ekipa splavara sastavljena od $6-8$ majstora. Obično su gradili usporedno više splavi (po $4-8$ fljojsi), jer se tako u grupama kasnije i plovilo Dravom (i Dunavom). Splavi su se gradile i tovarile izravno na pristaništu (lenti, pristanu), početno na obali i potom na vodi, a za tovarenje (nakladanje) drvne građe koristili su se i pomoćni radnici. Splavar je za gradnju fljojsa imao vrlo oskudan i jednostavan alat: dvije sjekirice (zvali su ih flosar$k e)$, zatim dva cepina, ručnu pilu (na jednu ruku) te ručno svrdlo srednje veličine (sveder, uglavnom za provrtavanje rupa do jednog cola). ${ }^{113}$

Na suhom, na obali, izrađivao se veći dio poda splavi. To su bile povezane grede (tramiči) debljine od 5 puta 6 do 7 puta 8 cola i primjerene dužine (prema dimenzijama splavi) stvarajući tako pravilnu konstrukciju poda. Nisu se smjele rabiti metalne žice, čavli ili kovačke klanfe već samo drvene poveznice koje su dobro učvrstile pod splavi. Za poveznice su se upotrebljavali najviše drveni klinci, promjera oko jednog cola, a dužine do $30 \mathrm{~cm}$. Uz klince, tramiči su se vezali i posebnim vrbovim šibama (trtama) koje su se uzgajale u vlažnom poloju Drave (klinci

112 Prema sjećanju dobravskog splavara Andrije Vugrinčića, iz Slovenije su uglavnom doplovile Dravom manje splavi veličine oko 22 puta $6 \mathrm{~m}$, a potom su se fljojsi na dobravskoj lenti prepravljali u veće splavi - dužine i više od 32 m. Izjavu pribilježio Dragutin Feletar 1967. godine. Dragutin Feletar, Iz povijesti Međimurja, Matica hrvatska, Čakovec, 1968., 191.

113 Franjo Pahernik, Šajke in splavi na Dravi, o.c., 17-18; Prema sjećanju dobravskih splavara, pribilježio Dragutin Feletar 1967. godine. 


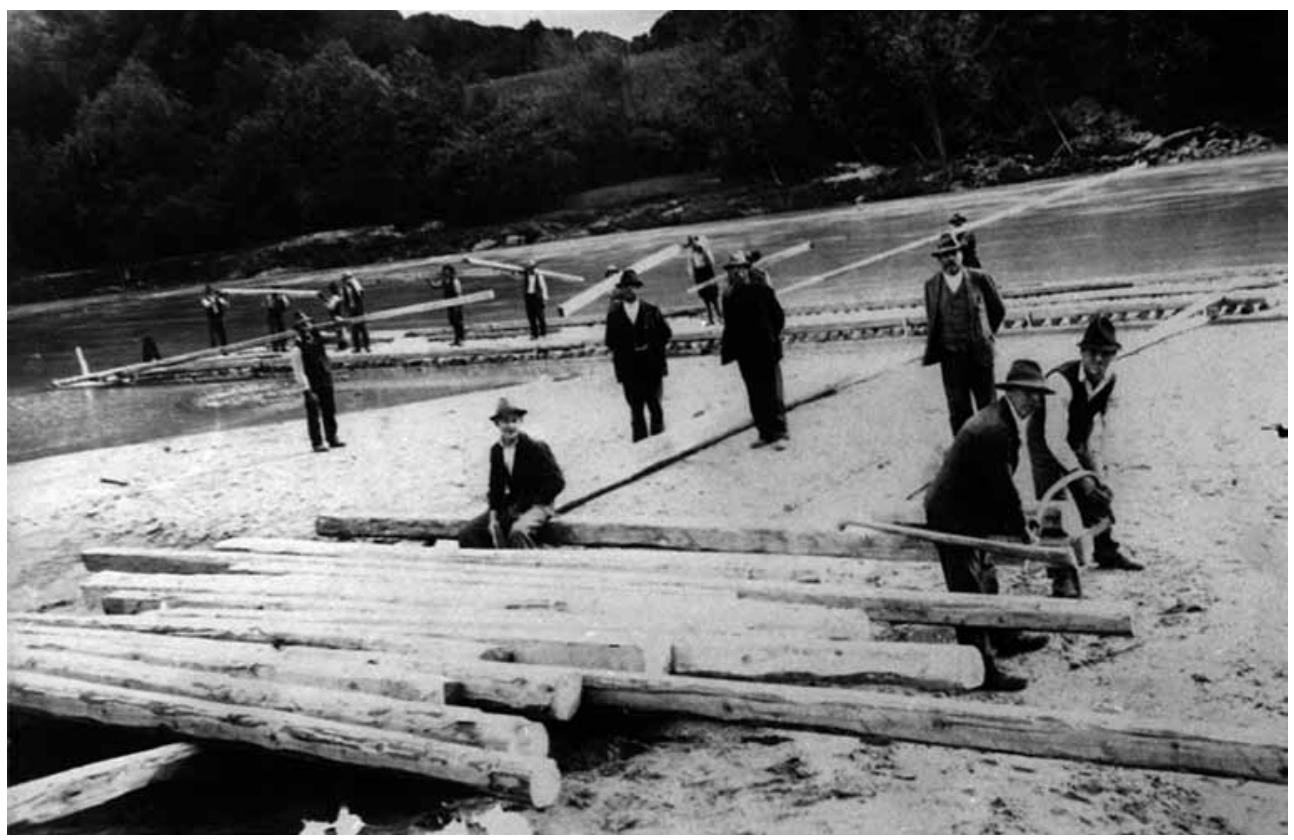

Slika 26. Počelo je „nakladanje“ splavi - snimljeno 1920-ih godina kod Podvelke (Drava nekoč i danes, 2000.)

su se ručno izrađivali od smrekova ili lipova drva). ${ }^{114}$ Cijeli pod stabiliziran je stavljanjem poprečnih greda, tzv. iberlegera, koji su za tramiče poda bili čvrsto povezani drvenim klincima i trtama (gožvama). ${ }^{115}$

Tako učvršćen pod splavi potom se s obale spušta u vodu te se tamo završava konstrukcija i potom naklada drvna građa. Konstrukcija splavi još se učvršćuje tzv. tablanjem - stavljaju se na pod tramiči prereza 3 puta 4 ili 4 puta 5 cola. Na takvu čvrstu konstrukciju (ukupne dužine oko $32 \mathrm{~m}$, na prednjoj strani širine 6 $\mathrm{m}$ i zadnjoj strani $5 \mathrm{~m}$ ) počelo je potom slaganje drvne građe. Tovarila se obično piljena (manje tesana) građa - grede, fosli, daske, letve, roženice, ali ponekad i sitnija drvna galanterija ili pak vinogradarsko kolje i slična roba. U prvoj nakladi na podu stavljala se deblja građa i po cijeloj površini, zatim se u drugoj nakladi stavljala nešto kraća i uža građa - tako do osme naklade - na vrhu je građa bila barem 2 m kraća i isto toliko uža. Natovarena građa bila je čvrsto povezana

\footnotetext{
114 Dragutin Šafar, „Doljnja rajža“ - Vukovar - Bata, Dobravske novine, Općina Donja Dubrava, 25. 12. 2008.

115 Franjo Pahernik, Šajke in splavi na Dravi, o.c., 18. Gornje grede ili überlegeri obično su bile debljine 4 puta 5 cola.
} 
(klincima i gožvama), a na vrhu splavi obično se napravila drvena „kućica“ od dasaka, kao sklonište u slučaju ružnoga vremena. Gožvama ili trtama s prednje strane, kao i sa zadnje, bila su vezana po tri vesla (plovidbom je ravnalo 6 splavara, od kojih je jedan bio glavni kormanuš). ${ }^{116}$

$\mathrm{S}$ obje strane splavi bila je privezana najdeblja greda na fljojsu - to je $\mathrm{tzv}$. konj, greda duga kao i splav (oko $30 \mathrm{~m}$ ) i debela 8 - 10 cola, koja je učvršćivala i osiguravala bokove splavi, ali i služila i za sigurnost plovidbe. Dragutin Šafar o tzv. konju piše: „Taj je „konj“ služio splavarima u slučaju ako im se splav nasuče na kakvom pličaku. Tada bi otkačili „konja“ i privezali užetom, odguravali bi ga čakljama na sredinu brzaca, pa je on svojom težinom povukao cijelu splav s pličaka“" ${ }^{117} \mathrm{Na}$ splavi, obično uz zaštitnu kućicu od dasaka, nalazilo se i ognjište - na daskama se poredalo desetak busena ( $p a z ̌ a)$ zemlje s travom, na kojima se palila vatra za spremanje hrane. Uz splav je obično bio privezan i dravski čamac (čon) zbog potrebnih odlazaka na obalu ili na drugu splav. Prosječno se na „,̌tajersku“" splav natovarivalo oko 90 kubika drvne građe, a dalje od Donje Dubrave na fljojsima bilo je nakladano i 130 i više kubika drva. Tako natovareni splav obično je imao gaz (grezi) $50-80 \mathrm{~cm}$ (maksimalno je bilo dozvoljeno $1 \mathrm{~m}$ ), pa je i te kako trebalo paziti na brojne plićake i nanose panjeva na hirovitoj Dravi. ${ }^{118}$ Splavi su u pravilu pristajale samo na (razmjerno) uređenim pristaništima (pristanima, lentama), osim ako se moralo stati zbog virova i drugih opasnosti. Vezali su se užadi raznih debljina, uglavnom do pola cola. Užad za splavi izrađivali su specijalizirani užari, čije su obitelji u pravilu uzgajale i veće količine konoplje (namakale su se u rukavcima Drave). Poznati užari djelovali su osobito u Donjoj Dubravi, Legradu, Dupleku i drugdje.

Da je sigurna plovidba splavi po Dravi bila pravo „mornarsko“ umijeće, govori podatak da je srednje velika splav bila teška oko $55.000 \mathrm{~kg}$. Naime, kubični metar drvne građe (jele, smreke) bio je u prosjeku težak blizu $700 \mathrm{~kg}$, a na srednje velikom fljojsu bilo je nakladano oko 80 kubika građe. Splavi, koje su se preslagivale u Donjoj Dubravi (pa počesto po dvije splavi spajale u Ferdinandovcu ili Čađavici), imale su i više od 120 kubika drva, odnosno gotovo 80.000 kg težine. Bila je to plovna grdosija kojom je bio pravi kunst kormilariti brzacima Drave, a posade su morale biti vrlo izbježbane i iskusne (pogotovo glavni kormanuši). ${ }^{119}$

$\overline{116}$ Maja Kanop, Drava - negdaj plovna reka, o.c., 175-176; Ivan Verboten, Peter Macuh, Ohranjanje splavarskega izročila - rancarija, o.c., 262-366; Franjo Pahernik, Šajke in splavi na Dravi, o.c., 18-19.

117 Dragutin Šafar, „Doljnja rajža“.., o.c., 18.

118 Franjo Pahernik, Šajke in splavi na Dravi, o.c., 18-19.

119 Kubik svježe posječene smreke, s 15 posto vlage, bio je težak oko $740 \mathrm{~kg}$, a suho drvo vagalo je 470 kg. Kubik bijele jele vagao je oko $460 \mathrm{~kg}$. Nosivost srednje velikog splava bila je ekvivalent težini oko 100 putnika. Ivan Verboten, Peter Macuh, Ohranjenje splavarskega.., o.c., 368. 


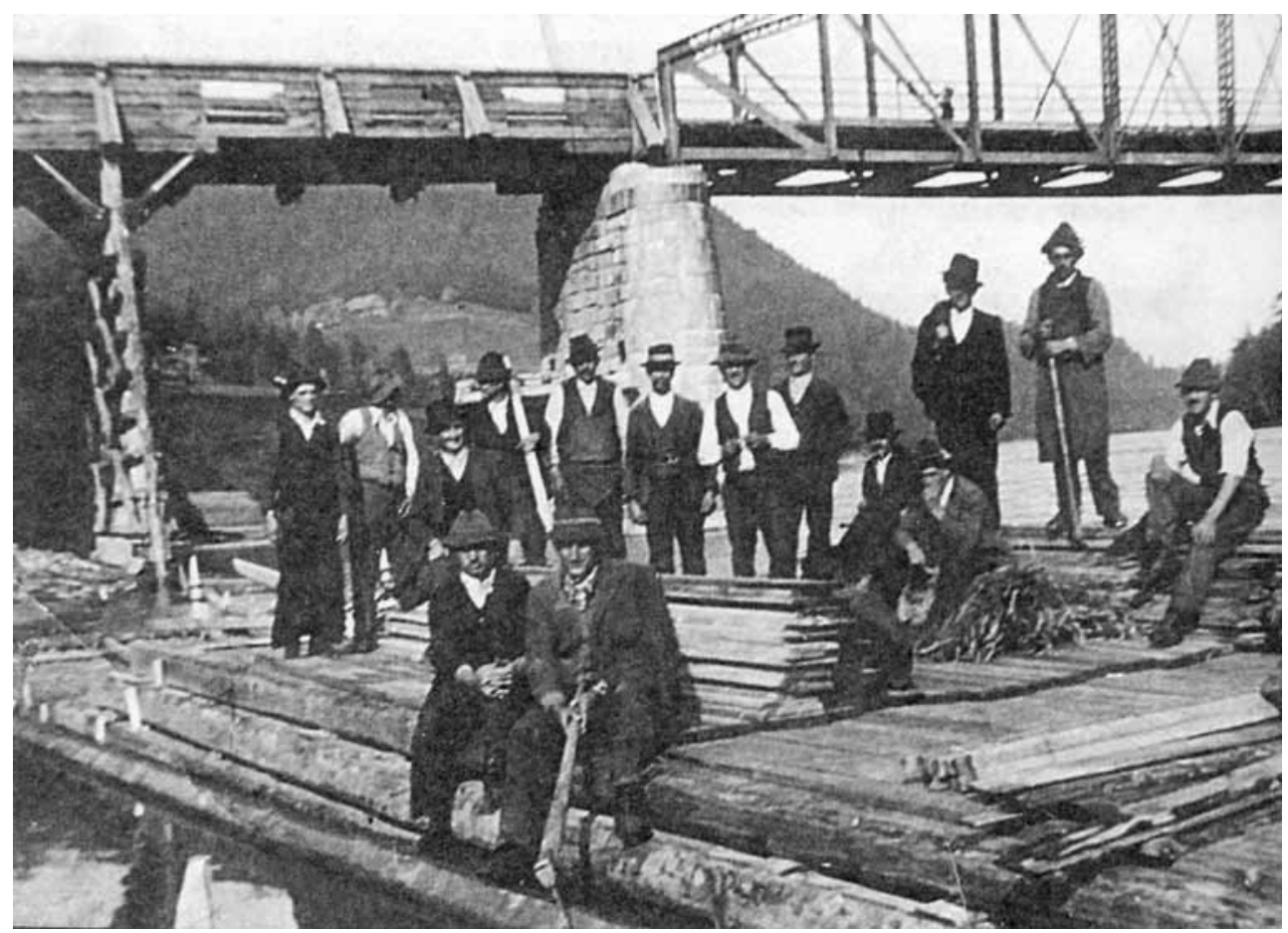

Slika 27. Skupina splavara snimljena na splavi kod mosta u Vuhredu 1938. godine (Drava nekoč in danes, 2000.)

O važnosti splavarstva, primjerice za kraj oko Fale, te o nosivosti fljojsa, za razdoblje potkraj 19. stoljeća, Maja Kanop navodi: „Letno se iz tega okraja odpravi 150 do 200 splavov. Na en splav se lehko naloži 6.000 do 7.000 desk, dolžine po 10 čevljev $(136 \mathrm{~cm})$, širine $5 \mathrm{col}(13 \mathrm{~cm})$ in debljine pol cole, ali 10.000 strešnih letev, dolžine 2 klaftri $(3,78 \mathrm{~cm})$, debljine 1,5 cole $(4 \mathrm{~cm})$ in širine 2 coli, ali 2.000 desk za pod, dolžine 2 klaftri, širine en čevelj in debeline 1,5 col. Okoli 150 splavov letno odpelje lesa v vrednosti 85.000 golddinarjev. Eno šestino te svote je treba odšteti za prevoz nazaj in tako iznaša zaslužek od letne prodaje lesa $v$ falskem nabornem okraju 71.000 golddinarjev. ${ }^{\prime \prime 20}$

Koliki je promet splavima bio po Dravi i kako je veliko značenje imalo splavarstvo za gospodarstvo priobalnog stanovništva, najbolje dokumentiraju po-

$\overline{120}$ Maja Kanop, Drava - negdaj plovna reka, o.c., 160. 
daci Šumskog odsjeka (Gozdnoga odseka) Banske uprave u Ljubljani za 1938. godinu (kada je splavarstvo već polako išlo prema svojem zalazu): iz pristaništa (lenštata) u slovenskom dijelu Drave otpremljeno 1.167 splavi (flosa) - iz lenštata Libeliče 19 splavi, Dravograd 474, Gortina 5, Trbonje 7, Sv. Ožbalt 93, Sv. Lovrenc 26, Fala 37, Ruše 16, Vuzenica 81, Muta 23, Radlje 89, Vuhred 43, Brezno 189, Selnica 28, Bresternica 7, Jelovec 23 i Maribor 7 splavi. Drvo se rijekama i kanalima (nakraju djelomice i željeznicom) distribuiralo u sljedeća pristaništa: Maribor 39 splavi, Ptuj 5, Borl 2, Varaždin 33, Donja Dubrava 138, ${ }^{121}$ Legrad 1, Barč 99, Moslavina 12, Belišće 4, Osijek 74, Dalj 8, Bogojevo 68, Vukovar 138, Ilok 9, Bačka Palanka 96, Novi Sad 110, Sremska Kamenica 4, Slankamen 40, Stara Pazova 13, Banovci 7, Beograd 15, Pančevo 4, Kovin 8, Apatin 1, Bezdan 34, Crvenka 2, Sombor 5, Kula 1, Srbobran 4, Sivac 8, Bački Breg 3, Titel 2, Novi Bečej 28, Stari Bečej 26, Stara Kaniža 11, Opovo 2, Petrograd (Veliki Bečkerek, Zrenjanin) 89, Temišvar 8 i Veliko Gradište 20 splavi. ${ }^{122}$

\section{ZNAČAJKE I ORGANIZACIJA PLOVIDBE, ŽIVOT SPLAVARA}

Splavari i šajkaši u pravilu su se regrutirali iz siromašnih obitelji, koje nisu imale zemlje za obrađivanje, a nisu mogli ni otvoriti kakav obrt ili sličnu djelatnost. Dva revira uz Dravu bila su osnovno izvorište za regrutiranje splavara. To je područje štajerskog (slovenskog) porječja Drave, od Libeliča do Dupleka, koje su još zvali dolina flojsarjev te kraj oko sutoka Mure i Drave - sa središtem u Donjoj Dubravi (pokoji fljojsar bio je i iz Kotoribe, Donjeg Vidovca, Svete Marije, Legrada ili iz zaselaka Novoga Virja i Drnja). Dolina flojsarjev između dva rata u sezoni je brojila i više od 500 aktivnih splavara, tim više što je u to vrijeme gotovo propalo fužinarstvo i glažutarstvo te razni obrti kućne radinosti. Oko Donje Dubrave vladala je pak tradicionalna "glad za zemljom“, jer je Međimurje i pridravski dio Podravine pregusto naseljen da bi stanovnici mogli živjeti samo od poljodjelstva. Izlaz se tražio u splavarstvu, ispiranju zlata na dravskim produjinama, kućnoj radinosti, foringaštvu i sličnim djelatnostima (uz početak emigracije još prije Prvoga svjetskoga rata). A to je bio kruh sa „sedam kora“. Samo u Donjoj Dubravi radilo je oko 100 splavara, te je u mjestu formirana posebna siromašna četvrt uz Dravu - Prekop - pun malih potleušica pokrivenih slamom. U Sloveniji su splavari zimi, kada se nije plovilo, radili na sječi šuma i dopremanju

\footnotetext{
$\overline{121}$ Godine 1938. već (od 1934.) glavna tvrtka za promet drvom iz Donje Dubrave Ujlaki-Hirschler i sin je bila u stečaju, ali su novoosnovane firme (Kaufmann, Steiner, Rado) još uvijek kupovale i prometovale znatnim količinama drvne građe (i uz transport u pilanu u Kotoribi).

122 Ivan Verboten, Peter Macuh, Splavarstvo na Dravi in Donavi, Drava nekoč in danes, Založba Obzorja, Maribor, 2000., 256-258.
} 


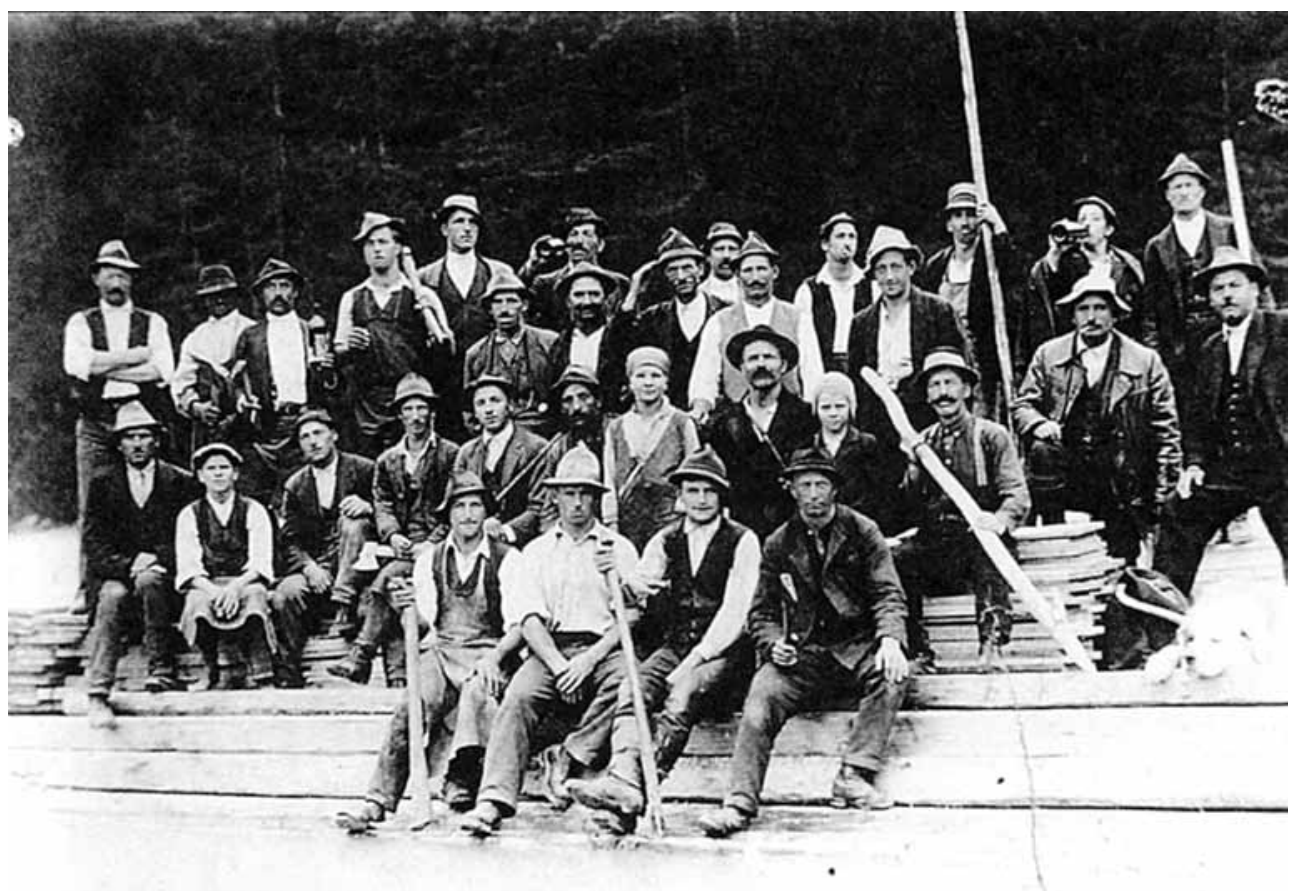

Slika 28. Splavari snimljeni na susretu u Breznom 1933. godine (Drava nekoč in danes, 2000.)

drva do dravskih obala, a u Donjoj Dubravi na pilanskim i skladišnim poslovima tvrtke Ujlaki-Hirschler i sin ili u kućnoj radinosti. ${ }^{123}$

Iako je dokumentacija o splavarstvu na Dravi uglavnom zagubljena, još bi valjalo provesti dodatna istraživanja o popisima dravskih mornara - to se pogotovo odnosi na sela oko sutoka Mure u Dravu, gdje se o starim fljojsarima može doznati tek iz pričanja najstarijih stanovnika. Imao sam sreću još 1967. u razgovoru sa splavarom Andrijom Vugrinčićem i službenikom kod Hirschlera, Ivanom Vučenikom, doznati neka imena dravskih kormanuša i fljojsara. U 1967. još su u Donjoj Dubravi bili živi fljojsari, uz Andriju Vugrinčića: Josip Miser, Andrija Jančec, Đuro Bogomolec, Đuro Kolarić, Stjepan Mikulan, Đuro Jakupak, Stjepan Punčikar i drugi. Oni su se sjetili imena nekadašnjih dobravskih splavara, kao što su bili Antun Kralj, Stjepan Duhović, Josip Toplek, Stjepan Mikulan, Franjo Bogomolec, Ivan Ujlaki i brojni drugi. ${ }^{124}$ Dragutin Šafar pak spominje da

\footnotetext{
123 Dragutin Feletar, Hrvoje Petrić, Donja Dubrava - središte splavarstva na rijeci Dravi, Ekonomska i ekohistorija, 3, Zagreb, 2007., 156-181; Maja Kanop, Drava - negdaj plovna reka, o.c., 188-189.

124 Dragutin Feletar, Iz povijesti Međimurja, o.c., 189-192.
} 
su u Donju Dubravu između dvaju svjetskih ratova obvezno dolazili slovenski splavari (gospodari, kormanuši, gazde) - braća Šarman, Franc Neslin, Jakeci, Miha Pušnik, Vincenc Berklin, Franc Sajfer i drugi (odsjedali su uglavnom u znamenitoj dobravskoj krčmi Rusak). ${ }^{125}$

U starom slovenskom flosarskom središtu - Brezno, Podvelka, Javnik, Ožbalt - radio je velik broj splavara, koji su nosili ukupno splavarstvo na Dravi $\mathrm{u}$ vrijeme stare Jugoslavije. Dobar dio njih plovio je do Donje Dubrave, a neki su produžili plovidbu sve do Smedereva i dalje. Ivan Verboten i Peter Macuh spominje većinu od njih: „kormaniše i gospodarje“ iz obitelji Cepec - Jakob (rođen 1867.), Feliks (1884.), Ivan (1888.), Mihael (1875.) Martin (1895.) i Ludvig (1908.), zatim iz obitelji Šarman - Franc (1872.), Peter (1886.), Feliks (1903.), Franc (1905.), Konrad (1904.), Jakob (1912.), Ernest (1920.) i Miha (1920.), pa Matevž Čas (1911.), Jurij Donik (1901.), Ivan Ketiš (1900.), Franc Namestnik (1906.), Simon Peteržinek (1894.), Anton Ropič (1908.), Karel Pušnik (1902.), Anton Vrečko (1873.), Franc Vrečko (1908.), Ivan Vanč Verboten (1920.), Fric Volmajer (1884.), Ivan Volmajer (1918.), Ivan Žavcer (1900.), Ferdinand Žunko (1901.), Pavel Žunko (1894.), Rajko Ditinger, Jurij Altbauer (1907.), Anton Strnad (1911.), Franc Hitl (1895.), Janeš Tulč, Leopold Potnik (1898.) i Jože Langbauer. ${ }^{126}$

Iz spomenutoga područja bili su i pomoćnici kormanuša, tzv. ravnjaki, koji su bili važni u ravnanju plovidbe splavi: Maks Jarc (rođen 1907.), Lovrenc Halužan (1908.), Luka Koren (1864.), Franc Petar (1911.), Josip Pušnik (1911.), Miha Pušnik (1916.), Albin Ropič (1901.), Štefan Smolnik (1914.), Franc Viltužnik (1911.), Vincenc Volmajer (1901.), Ivan Žavcer, Mirko Jarc (1909.), Franc Koležnik, Ivan Koren (1902.), Alojz Petar (1922.), Konrad Pušnik (1912.), Anton Pušnik (1917.), Florijan Ropič, Miha Špilman, Fridl Viltužnik (1905.) i Fric Volmajer (1888.). Splavarski momci (redni splavarji) bili su: Josip Pušnik (rođen 1870.), Feliks Donik (1897.), Rajko Adam (1922.), Ivan Alt, Ivan Šlager, Kristl Petržinek (1891.), Peter Adam (1897.), Marko Levar, Anton Alt, Ivan Reš, Kristl Žavcer, Ivan Pušnik (1921.), Alojz Miklavc, Anton Peter (1916.), Ivan Ropič (1916.), Peter Kočunik (1912.), Franc Kočunik, Andrej Vrčko (1897.), Martin Golob, Florijan Kositer (1902.), Peter Rozman (1864.), Ivan Požarni (1910.), Alojz Smode, Feliks Lubas, Jakob Ertl, Jože Medved, Ivan Edler, Viktor Anželak, Avgust Češnik (1901.), Jakob Lahovnik (1918.), Blaž Žavcer, Eric Novak, Adolf Šarman, Ivan Viltužnik (1891.), Jernej Viltužnik (1895.), Pavel Viltužnik (1899.), Ferdinand Viltužnik (1916.), Franc Žebrek (1922.), Krist Jarc (1916.), Adam Požarnik (1886.), Franc Tertinek (1898.), Ivan Ropič (1908.), AdoIf Beričič (1903.), Vincenc Kočunik, Miha Koren (1905.), Ivan Ketiš (1921.), Ivan

\footnotetext{
125 Dragutin Šafar, „Doljnja rajža“ - Vukovar-Bata, o.c., 18.

126 Ivan Verboten, Peter Macuh, Splavarstvo na Dravi in Donavi, o.c., 252-255.
} 
Strnad (1922.), Karel Kositer (1904.), Anton Rozman, Jurij Rebernik (1910.), Alojz Smolnik, Milan Germut, Ivan Navodnik, Anton Kelemberger, Peter Stepišnik, (1900.), Alojz Tertinek (1912.), Avgust Kotnik (1917.), Tomaž Sušek (1892.), Anton Krajnc (1910.), Rudolf Šarman, Franc Vogrin, Rudolf Viltužnik (1893.), Feliks Viltužnik (1896.), Miha Viltužnik (1903.), Ivan Krapše i Andrej Suček. Povremeni splavari bili su: Maks Čac (rođen 1909.), Jože Harman (1909.), Jurij Murko (1901.), Rajmund Ditinger, Ivan Čas, Rudolf Lubej (1909.), Franc Štrablek (1920.), Ernest Sabathi (1898., trgovac drvom iz Podvelke) i Franc Tertinek
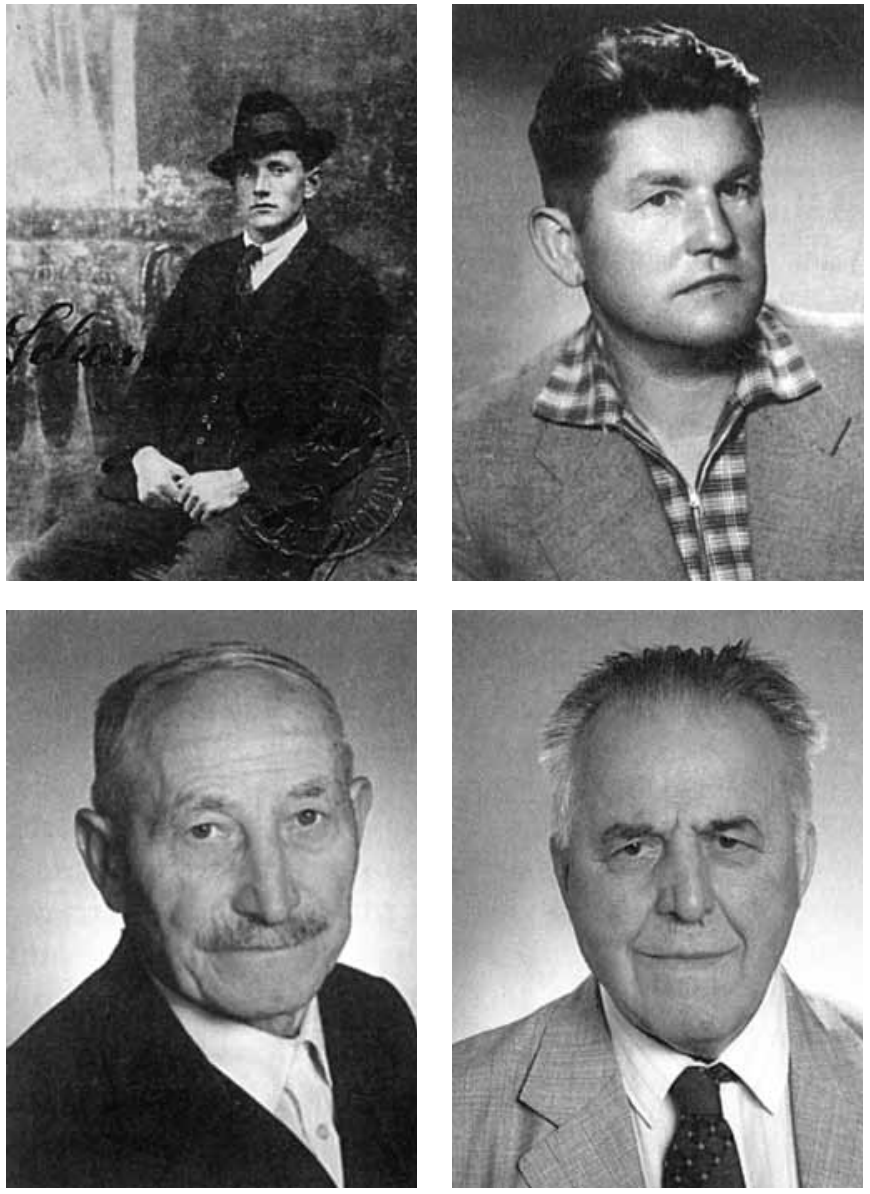

Slika 29. Neki od zadnjih splavara iz "doline flosarjev": Franc Šarman, Ivan Vanč Verboten, Štefan Smolnik i Miha Viltužnik (Drava nekoč in danes, 2000.)

(1898.). Svi ti kormanuši i splavari imali su prijateljske i poslovne veze s Donjom Dubravom, a svi su oni bili kršteni splavarskim obredom u dobravskoj krčmi Rusak. ${ }^{127}$ Mnogo je splavara bilo iz drugih slovenskih priobalnih naselja, kao i trgovaca drvom a koji su ujedno bili i vrsni kormanuši na splavima - poput Jožeta Brega iz Vuhreda, Franca Bračka iz Jelovca, Franca Šarmana iz Podvelke (Ožbalta) i drugih. ${ }^{128}$

\footnotetext{
127 Ivan Verboten, Peter Macuh, Splavarstvo na Dravi in Donavi, o.c., 253-254; Dragutin Šafar, Dubravska restauracija Rusak nekoć, o.c., 24.

128 Ivan Verboten, Peter Macuh, Splavarstvo na Dravi in Donavi, o.c., 205, 2019, 225-226.
} 


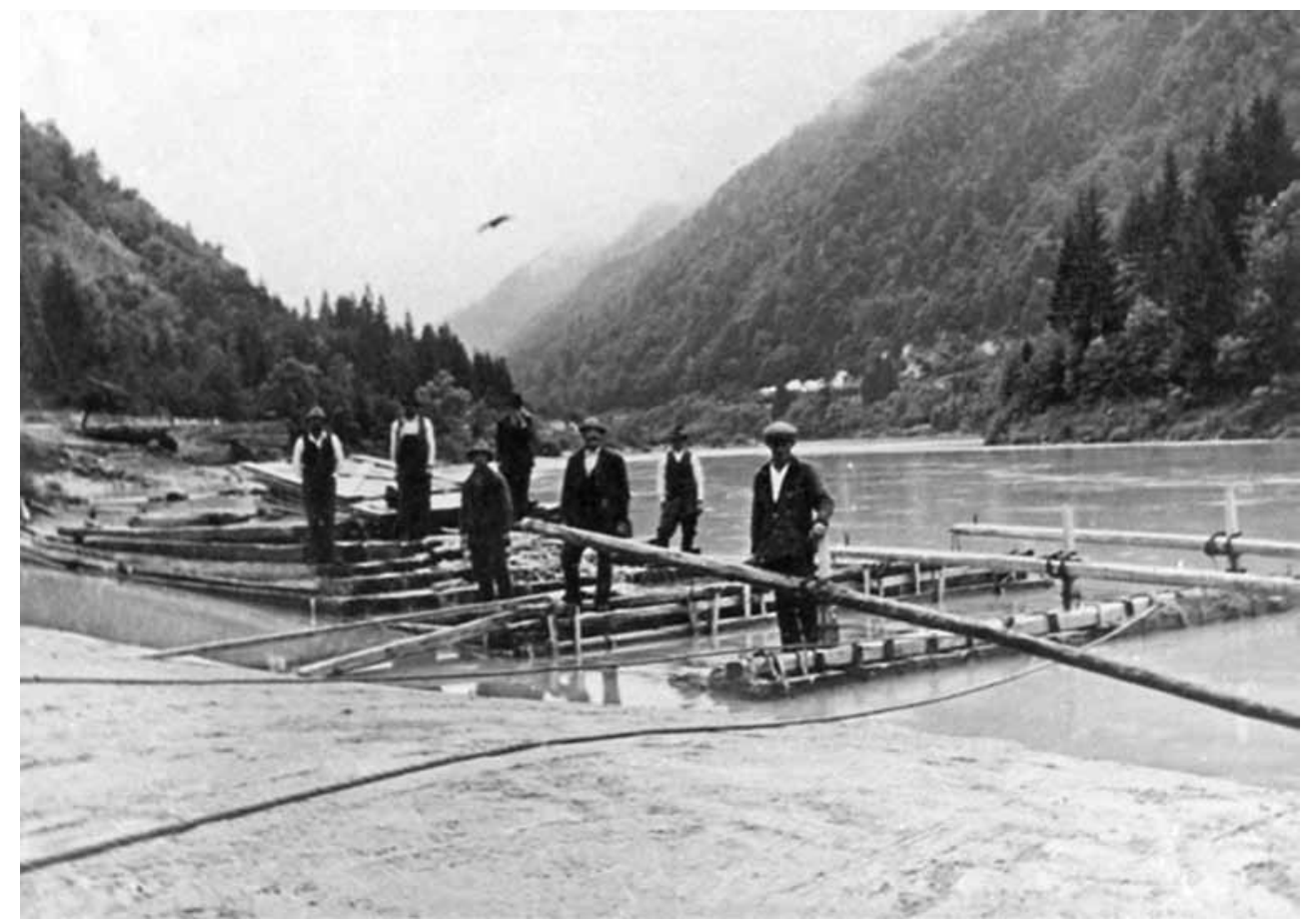

Slika 30. Na pristaništu splavi kod Ožbalta 1930-ih godina (Splavarski muzej u Javniku)

Jednu splav opsluživalo je (od nastanka ili povezivanja, plovidbe do rastepanja u zadnjem pristaništu) šest flosara. Po stupnju njihove spreme i iskustva, to su bili kormaniš in pet hlapcev. Kormanuš je na splavi bio naprijed desno za glavnim veslom (lemezom), a kraj njega su bila dva splavara prednjaka. Otraga desno za ravnajućim veslom bio je splavar-ravnjak ili nachfarer te još dva flosara. ${ }^{129}$ Ivan Verboten i Peter Macuh navode nazive splavara, koji su u pravilu bili korišteni duž slovenskog i hrvatskog toka Drave (s manjim varijantama). To su: flosar početnik (obično su bila na splavi dva takva momka i nalazila su se za veslima na zadnjem dijelu splavi), flosar zadnjak, flosar prednjak, flosar ravnjak ili nadfarer, kormanuš (kapitan), flosar vicegospodar i flosarski gospodar (obrtnik ili vođa ekipe kojeg je imenovao veletrgovac ili vlasnik splavi). ${ }^{130}$ Dragutin Šafar (Donja Dubrava) pak navodi da je „na svakom splavu posadu vodio kormanuš-upravljač, koji bi birao nadfarera i četiri dečka. Kormanuš je uvijek bio naprijed, skrajnje desno za veslom, a nadfarer ili glavni veslač otraga, također s desne strane splava. Kod normalnih

\footnotetext{
129 Franjo Pahernik, Šajke in splavi na Dravi, o.c., 19.

130 Ivan Verboten, Peter Macuh, Splavarstvo na Dravi in Donavi, o.c., 226-228.
} 
uvjeta plovidbe bi trojica ili četvorica stajala i držala rukom vesla (lemez) spuštena u vodu, a ostali bi se po redu odmarali, sjedeći sa podignutim veslom, zakačenim pomoću u krug vezanim trtama ili vrbovim gožvama. Samo kod raznih prepreka i opasnih mjesta na rijeci, koja bi izvrsno poznavao kormanuš, bi se sva šestorica hvatali za vesla i sinhronizirano radili po komandi kormanuša. ${ }^{" 131}$

Splavar Miha Viltužnik iz Brezna pripovijeda: „Navadno nas je bilo na enem splavu šest moških, na primer iz Brezna do Dubrave. Vseh skupaj nas je bilo 24, ker smo večinom peljali štiri splave. V Dubravi do navadno 16 naših splavarjev, ki so odšli nazaj proti domu, zamenjali so Hrvatje. Oni so se peljali z nami do Vizvara. Potem so oni tudi odšli nazaj domov. Tam smo tudi skupaj zvezali po dva flosa, tako so na vsakem ostali po štirje naši flosari, kormaniš, prednjak, nadfarer in hlapec. Do končne postaje nas je šlo osem na dveh splavih. Za to smo dobili celo dnevnico, to je 500 dinarjev, tisti pa, ki so se vrnili iz Dubrave, pa polovično. Hrvatje so zaslužili na dan kot mi, po 20 dinarjev. ${ }^{\prime 132}$

Plovidba fljojsima, prema dobravskim fljojsarima, ugrubo se dijelila na tri velike etape. Od Libeliča i Dravograda do Donje Dubrave bila je zašumska ili gornja rajža, zatim nizinskim tokom Drave - šumska rajža (plovilo se kroz zelenilo pridravskih šuma), a po Dunavu i pritocima bila je dolinja rajža ${ }^{133}$ Najzahtjevnija je svakako bila gornja rajža, iako su se u rijeci i nizvodno od Donje Dubrave skrivale razne zamke, pogotovo za visokih voda i nakon njih. Drava je u pravilu po dva do tri zimska mjeseca bila smrznuta rijeka, pa se plovilo od početka proljeća do kraja jeseni. „Na proljeće, prvim splavom (zvali su ga fljojs-cujzek) od tri vagona piljene i tesane građe, bi se pokusno plovilo do Donje Dubrave, kao izvidnica o plovnosti rijeke. Uvijek je sve zavisilo od vodostaja rijeke. Za splavarenje niski kao i visoki vodostaj bio je najopasniji. Zato se srednji vodostaj obilato iskorištavao za plovidbu. Bili su ponekad povoljni uvjeti da su se već u Donjoj Dubravi (a ne tek u Vizvaru) mogla vezati po dva splava i uspješno ploviti dalje nizvodno. Oni su obično plovili na doljnju rajžu, dakle po Dunavu. Ponekad bi iskusni dubravski splavari plovili i preko Đerdapa, sve do Turnu Sverina, ulazili u Tisu, gdje bi ih uzvodno vukli brodovi-tegljači i u banatskim pristaništima isporučivali drvo. ${ }^{\prime 134}$

$\overline{131}$ Dragutin Šafar, „Doljnja rajža“.., o.c., 18

132 Ivan Verboten, Peter Macuh, Splavarstvo na Dravi in Donavi, o.c., 233; Flosarski gospodar Franc Šarman (zvan i dravski kralj splavara) je nove splavare u Donjoj Dubravi obično birao u krčmi Rusak (Rusača), a pogotovo je pomno pazio izabrati što bolje kormanuše, koji su bili odgovorni za ljude, splav i plovidbu.

133 Dragutin Šafar, „,Doljnja rajža“.., o.c., 18; Franjo Pahernik, Šajke in splavi na Dravi, o.c., 28-30.

134 Prema pričanju još živih splavara 1967. godine u Donjoj Dubravi, pribilježio Dragutin Feletar. 
Na sve tri rajže - zgornju ili zašumsku, šumsku i doljnju - bilo je poteškoća u plovidbi, a kormanuši su svako proljeće, ploveći na probnoj splavi (fljojs-cujzek), dobro upoznavali i pamtili nesigurne točke. Osobite probleme kod plovidbe stvarali su plićaci, čija se pozicija stalno mijenjala (pa i za samo jednu godinu) te virovi i bujice koje su „najedale“ obalu i posebnom brzinom nosile splav prema obali. Te su bujice (pogotovo nakon visokih voda) nosile mnogobrojne panjeve, klade i druge kabaste predmete, te ih ostavljale na dnu rijeke, što je bila velika opasnost za nasukavanje i destabilizaciju splavi. Iskusni kormanuši već su po obliku minivalova i načina toka vode znali prepoznati gdje je kolika dubina i je li pod vodom kakav panj. Tu je vladala i velika solidarnost u plovidbi, jer su se kormanuši vrlo brzo i iscrpno međusobno obavještavali o stanju korita rijeke. Na Dravi i Dunavu bilo je i stalnih, dobro poznatih "crnih točki", pogotovo plovidba velikih splavi ispod mostova, zatim kroz prevodnicu HE Fala (nakon 1918.), kroz kanjonski dio Drave u Sloveniji, plićake na Dravi nizvodno od Vizvara itd. ${ }^{135}$ Po noći se vozilo samo ako su bili probijeni rokovi isporuke drva, ali je tada moralo biti vedro vrijeme $i$ mjesečina. Franjo Pahernik o tomu piše: „Po noči so vozili splave iz Belišća naprej le v jasni mesečini, po Donavi pak ob lepom vremenu brez vetra i megle. ${ }^{.136}$

S obzirom na to da su hranu splavari sami osiguravali, prehrana je bila jednolična. Mnogo se pilo (domaće rakije i cvičeka), a dobro su poslovale krčme u svim pristaništima uz Dravu i Dunav. Dobravskifljojsari na splavi su kuhali čak i domaću juhu - žene su im u čarape spremile posušenu zapršku (zafriga), koju su stavljali u vruću vodu, uz dodatak domaćih rezanaca. ${ }^{137} \mathrm{O}$ prehrani slovenskih flosara Maja Kanop piše: „Hrano in pijačo so si splavarji morali priskrbeti sami, le v pristaniščih pri vožnji splavov je obrok kruha in vina po navadi plačal gospodar. Hrana je bila tako odvisna od posameznikovega gmotnega stanja. Po vožnji so splavarji sami kuhali na ognjišču, ki je bilo urejeno na vsakom splavu. Pogosto so jedli slanino, polento in kavo, pravzaprav njen nadomestek, pražena jajca, kruh. Med jedjo so sedeli na tleh oziroma na stopničasto naloženih deskah. Hrano so si hranili v nahrbnitkih, ki so bili v kolibi na splavi. Skoraj svi splavarji so kadili, v preteklosti pa žvečili tobak. Mnogi so tobak namakali v vino in ga nato čikali."

Splavari su noćili uglavnom na samoj splavi ili po škednjima u pristanišnim selima te u prenoćištima (gostionicama). „Prenočivali so splavarji večinom v ko-

\footnotetext{
$\overline{135}$ Franjo Pahernik, Šajke in splavi na Dravi, o.c., 26.

136 Takve domaće juhe bile su, zapravo, preteča današnjim instant juhama, a počeli su ih upotrebljavati još u barokno doba zlatari na Dravi, pogotovo iz Donjeg Vidovca, Donje Dubrave i Legrada, koji su na „turama“ ispiranja zlata na dravskim produjinama znali boraviti i po nekoliko tjedana. Krešimir Pavlic, Ispiranje zlata u Međimurju, Matica hrvatska, Čakovec, 2015.

Maja Kanop, Drava - negdaj plovna reka, o. c., 192.
} 


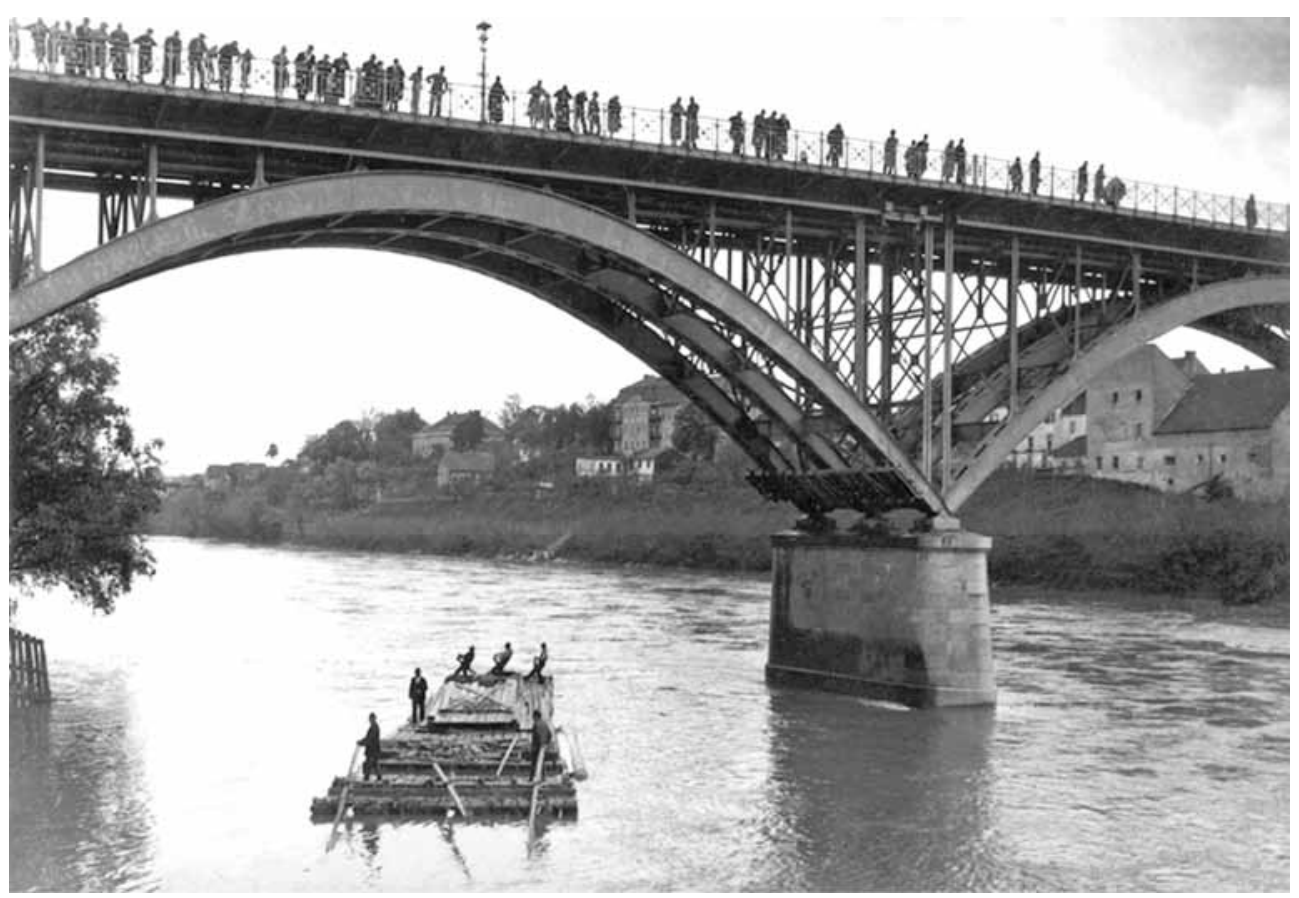

Slika 31. Splav na putu ispod mosta u Mariboru (Drava nekoč in danes, 2000.)

libi na krovu splava, izmenoma po štiri, postlano z slamo, pokriti so bili s koci, ob hladnem vremeno so zamašili špranje kolibe s slamo. Včasih so splavarji prenočevali v Ptuju, Borlu in Varaždinu, največ pa v Donji Dubravi in drugod po gostilnah in škednjih, gospodar transporta pa vedno v postelji. Obvezno je ostal vedno po eden stražar na splavi. Večina splavarjev ni bila vešča plavanja..." ${ }^{\prime 138}$

Splavarstvo i život na rijeci bio je vrlo težak i stresan zanat, počesto rizičan i opasan. Već obično pristajanje velikih splavi na pristaništu (pristanu, lenti, lenštatu) zahtijevalo je umijeće i velik fizički napor. „Dubravski fljojsari, koje bi u selu nazivali i šajkaši, na obali ili lenti bi dočekivali svoje slovenske pajdaše, te im pomagali pristajati splavovima. Zaustaviti na brzici splav bilo je dosta komplicirano - fljojs su jakim užadima i specijalno okovanim polugama, uz sudjelovanje nekoliko momaka, kao polugom parali po vodi da zaustave splav, te ga zatim debelim užetima vežu za drveće na obali. ${ }^{\text {“139 }}$ Znatno je teže bilo umiriti ili vezati splav u slučaju velikih bujica i virova, kada je matica nemilosrdno vukla fljojs u erodirajuću obalu.

\footnotetext{
138 Franjo Pahernik, Šajke in splavi na Dravi, o.c., 26-27.

139 Dragutin Šafar, „Doljnja rajža“.., o.c., 18.
} 
Zbog iznenadnih virova i brzaca, kakvog „podmuklog“ panja u rijeci ili pak zbog valova (na Dunavu), splavi su se ponekad znale naprosto razvezati i raspasti. O nesrećama splavara na Dravi i Dunavu narodna predaja u dolini splavarjev i u Donjoj Dubravi priča i živi još i danas. Stari kormanuš Andrija Vugrinčić iz Donje Dubrave 1967. ispričao je i svoju zgodu: „Naš fljojs sretno je prošao sve brzace i sakrite produjine na Dravi i već smo plovili naoko mirnim i širokim Dunavom. Međutim, kada smo bili blizu Slankamena vode Dunava iznenadno su se uzburkale od jakog vjetra i oluje, koja je upravo nailazila. Podigli su se veliki valovi i mi smo nekako uspjeli vezati splav uz obalu. Ali, kormanuš je ipak naredio pokret, vjerujući da je fljojs dovoljno čvrst da se bori i odoli valovima. Tek što smo se otisnuli od obale zahvatili su nas veliki valovi i fljojs se pod naletom bujice raspao. Na sreću cijela posada spasila se plivanjem na obalu. Baš tada transportirali smo na balvanima i piljenoj građi nekoliko tona letava, te su se one raspršile po velikoj površini Dunava. Kasnije smo spašavali što se spasiti dalo." ${ }^{\text {140 }}$

Posebno opasno bilo je flosariti u kanjonskom dijelu Drave u Sloveniji, gdje je Drava duboka, brza i nepredvidiva. Događale su se nesreće u kojima su splavari i smrtno stradavali. O jednom takvom događaju kormanuš Mihael Šarman (kojeg su nazvali dravski kralj) iz Podvelke priča: „Bilo je spomladi, leta 1936. V Vuzenici so splavili 32 metrov dolg splav. Po Podvelke je šlo kar v redu, podvelški valovi pa so bili tako visoki, da je val odnesel Feliksa s splava. Ni takoj utonil. Za splavom pri starem mostu je zopet prišel na površje in se obupno trudil, da bi s plavanjem dohitil splav. Valovi so ga divje peremetavali in preostali splavarji so nemočno opazovali Feliksov boj z Dravo. Nazadnje je izginil. Po štirinajstih dneh je Drava naplavila njegovo truplo pri Šturmu (tri kilometre pred Falo). ${ }^{\prime 141}$

Na beogradsko-smederevskom reviru Dunava za splavare je bila vrlo opasna i olujna košava, koja je dizala velike valove. O jednoj nesreći splavara kod sutoka Tise u Dunav, podvelški flosar Mihael Šarman pripovijeda: „Vozili smo flos za Banovce (izliv Tise v Donavo), štiri pa za Zemun. V Visovarju smo najeli dva Hrvata za doplšpanerja. Enemu je bilo ime Rok. Bil je zelo sposoben in na doplšpanerju je bil ober (kormaniš). Ponoči smo prispeli do Banovcev. Privezalo sme flose i odšli na suho. Pihal je močan veter košava, to je nekaj takega kot kraška burja. Valovi Donave so butali ko nori in flose je kar premetavalo in treskalo ob breg. Na enem se je podrla $u t a$. Les je ranil enega od Hrvatov - ober Rok pa je bil mrtev. Raztrgalo je vse štiri flose, les je odnašalo proti obali, ta se je trgala in zasipavala les. Na suhem smo z grozom opazovali kako voda, košava in zemlja uničujejo

\footnotetext{
${ }^{140}$ Dragutin Feletar, Iz povijesti Međimurja, o.c., 188-189.

141 Ivan Verboten, Peter Macuh, Splavarstvo na Dravi in Donavi, o.c., 223.
} 
naše delo in denar. Ko se košava malo polegla, sem si sposodil sidra, jih obesil na konje (dolgi bočni hlodi) in z njimi na Donavi zadržaval les raztrganih flosov. ${ }^{\prime 142}$

Splavari su u duhu svojega vremena bili bogobojazni ljudi, kršćanski odgojeni, a zbog svoga teškoga života često su se zavjetovali i prosili milost svetaca. Neke su svece posebno štovali. Glavni flosarski zavetnik bio je sv. Nikola (sv. Miklavž), koji je i inače zaštitnik putnika. Splavari su sv. Nikoli podizali pilove, kapele i crkve, pogotovo u Sloveniji. Crkva posvećena sv. Miklavžu spominje se u Vuzenici već 1238. godine, a kapela posvećena tom svecu podignuta je i u Sv. Lovrencu na Pohorju. I crkvu sv. Nikole u Miklavžu podigli su splavari - za tu crkvu su 1925. u Ožbaltu kupili zvono na kojem je ugravirano: „Sv. Miklavž, splavarji te častimo, na suhem in v vodi se ti v varstvo izročamo“. Splavari su se molili i sv. Ivanu Nepomuku te osobito sv. Majci Božjoj, nebeskoj zaštitinici Hrvata. Oni su slavili i sv. Martina, stoga što je oko Martinja završavala sezona plovidbe Dravom. ${ }^{133} \mathrm{U}$ povodu dana svetaca zaštitnika splavari su pohodili mise u crkvama, ali i priređivali raznovrsne svečanosti, susrete, natjecanja, pa i bogata gošćenja. Splavarske svečanosti u Donjoj Dubravi bile su sastavnim dijelom znamenitog margaljetskog proščenja (dana Sv. Margarete), sredinom srpnja.

Splavari su od svoje obitelji zbog plovidbe Dravom i Dunavom znali biti odvojeni i do tri tjedna, kojem roku valja još pribrojiti i nekoliko dana putovanja u povratku do Donje Dubrave ili do doline flosarja. Franjo Pahernik sastavio je i tablicu s trajanjem plovidbe od Dravograda do pojedinih pristaništa na Dravi, Dunavu i Tisi. Tako se od Dravograda do lenta u Mariboru moglo po normalnom vremenu i vodostaju stići za pola dana, do Ptuja za dan, a do glavnog poslovnog središta u Donjoj Dubravi do dva dana. Zatim je glavna točka bio Vizvar, do kuda se plovilo do 4 dana, a do Osijeka 7 dana, odnosno do ušća Drave u Dunav kod Aljmaša dan više. Dunavom do Vukovara plovilo se ukupno do 9 dana, a do Novoga Sada do 12 - što znači da je plovidba tihim Dunavom bila nešto sporija negoli brzom Dravom. Od Dravograda do Beograda trebalo je do 15 dana plovidbe, a do Velikog Gradišta nizvodno od Banatske Palanke i više od 20 dana (tablica 3.) Nakon prodaje splavi krajnjem kupcu, slijedio je povratak, koji je također bio mukotrpan i dugotrajan. Do izgradnje željeznica flosari su se najčešće vraćali na kakvim zaprežnim kolima ili pješke, rijetko poštanskom kočijom. Od druge polovice 19. stoljeća splavari su se za povratak uglavnom koristili željeznicom, a između dvaju svjetskih ratova i autobusnim linijama. Tako se splavari koji su išli na dolnju rajžu nisu vraćali kući i po četiri ili pet tjedana. Zato su u dolini flosarjov i u Donjoj Dubravi govorili da splavari imaju mornarski život - flosare iz Duple-

\footnotetext{
${ }^{142}$ Ivan Verboten, Peter Macuh, Splavarstvo na Dravi in Donavi, o.c., 224.

143 Ivan Verboten, Peter Macuh, Splavarstvo na Dravi in Donavi, o.c., 224.
} 
Tablica 3. Vrijeme plovidbe splavi, cijena prijevoza i visina naknade splavarima na relaciji od Dravograda do Velikog Gradišta 1938./1939. godine

\begin{tabular}{|l|c|c|c|}
\hline Relacija od Dravograda & $\begin{array}{c}\text { Trajanje } \\
\text { dana }\end{array}$ & $\begin{array}{c}\text { Cijena prevoza } \\
\text { dinara po } \mathrm{m}^{3}\end{array}$ & $\begin{array}{c}\text { Naknada splavaru - } \\
\text { dinara }\end{array}$ \\
\hline Maribor & $1 / 2$ & - & - \\
\hline Ptuj & 1 & - & - \\
\hline Donja Dubrava & $1-2$ & 48 & 200 \\
\hline Vizvar & $3-4$ & 55 & 350 \\
\hline Osijek (Essek) & 7 & 67 & 375 \\
\hline Aljmaš (Draueck) & $7-8$ & 70 & 475 \\
\hline Sombor (na kanalu) & $11-12$ & 90 & 400 \\
\hline Vukovar & $8-9$ & 70 & 450 \\
\hline Bačka Palanka & $10-11$ & 75 & 500 \\
\hline Novi Sad & $11-12$ & 80 & 575 \\
\hline Beograd (Banovci) & $14-15$ & 98 & 550 \\
\hline Slankamen & $12-13$ & 80 & 575 \\
\hline Titel (po Tisi) & $12-14$ & 85 & 600 \\
\hline Bečej (po Tisi) & $13-14$ & 100 & 750 \\
\hline Bela Crkva (Banska & $16-17$ & 110 & 700 \\
\hline Palanka) & $17-18$ & 120 & 800 \\
\hline Dubravica (na Moravi) & $17-20$ & 130 & \\
\hline Veliko Gradište & & &
\end{tabular}

Vrijeme plovidbe odnosi se na normalne vremenske prilike i vodostaj rijeke.

Izvor: Franjo Peharnik: Šajke in splavi na Dravi, Vuhred-Maribor, 1962., rukopis, 22

ka proizvali su dupleška mornarica, a glavni lenštat u Mariboru je u Mariborskim Benetkama (mariborska Venecija). ${ }^{14}$

Unatoč razmjerno dugim plovidbama, pa i razmjerno dobrim zaradama splavara, prijevoz drvne građe splavima Dravom i Dunavom bio je povoljniji i jeftiniji od prijevoza željeznicom još i u razdoblju do 1945. godine. Po kubičnom metru drvne građe fljojsari su prijevoz splavima (pred Drugi svjetski rat) računali od Maribora do Donje Dubrave do 50 dinara, do Osijeka oko 70 dinara, do Beograda oko 100 dinara te do Velikog Gradišta do oko 130 dinara (tablica 3.). Ako se uzme da je na velikoj splavi bilo i više od 130 kubika drva, zarada je bila za trgovce i organizatore plovidbe za tadašnje ekonomske prilike - vrlo povoljna. ${ }^{145} \mathrm{~S}$ obzirom na tu zaradu, ukidanje splavarstva nakon 1941. (1945.) imalo je

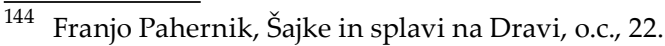

145 Franjo Pahernik, Šajke in splavi na Dravi, o.c., 22-23.
} 
vrlo nepovoljne efekte za ekonomiju u porječju Drave, pa je i izravno utjecalo, uz ostale faktore, na proces siromašenja stanovništva.

Izravne zarade splavara (i radnika vezanih za splavarstvo) u pravilu su bile uvijek nešto povoljnije nego $u$ drugim djelatnostima (pa i posao je bio nešto teži i opasniji). Ako su se pak splavarstvo i druge djelatnosti (kućna radinost, zlatarstvo, mlinarstvo, foringaštvo i sl.) nadopunjavali, onda su splavarske obitelji mogle normalnije živjeti. U 19. su stoljeću za vožnju splavima od Maribora do Donje Dubrave splavarski momci primali 6 gld (golddinara), ravnjaki oko $50 \mathrm{krc}$ (krajcara) više, dok su kormanuši primali oko 12 gld. Obični su splavari od Maribora do Osijeka primali plaću oko 17 gld, a kormanuši oko 28 gld. Plaća za plovidbu Dunavom proporcionalno se povećavala. ${ }^{146}$ Pred Drugi svjetski rat plaće fljojsara još su uvijek bile nešto povoljnije nego u drugim djelatnostima. Franjo Pahernik navodi da su splavari za plovidbu od Maribora do Donje Dubrave primali minimalno 150 dinara, do Vizvara minimalno 200 dinara, do Osijeka 350, do Vukovara 400, do Beograda 575 te do Velikog Gradišta minimalno 800 dinara. $\mathrm{Na}$ tu osnovnu plaću bilo je i nekih dodataka, zavisno od količine prevezenog drva i uvjeta plovidbe. Valja reći da su plaće fljojsara kod tvrtke Ujlaki-Hirschlelr i sin iz Donje Dubrave bile gotovo uvijek za nijansu povoljnije nego kod drugih poslodavaca (uz to, ta je firma uvelike socijalno i društveno pomagala stanovnicima sela). ${ }^{147}$

S obzirom na težak i usamljenički život na splavima, splavari su vrlo često veći dio plaće potrošili u gostionicama i drugdje. Zanimljivo je spomenuti da su slovenski splavari bili skrbniji i da su u pravilu veći dio zarade donosili svojim kućama, dok su dobravski fljojsari bili rastrošniji - bilo je slučajeva da kući nisu donijeli ni dinara. Stoga se u Prekopu, kvartu Donje Dubrave kraj Drave gdje su živjele fljojsarske obitelji, nastavilo živjeti vrlo siromašno, uz skromne stambene uvjete. Zato su odlično poslovale dobravske krčme i prenoćišta, a dobro posjećenih gostionica bilo je u svim pristaništima uz Dravu. O tomu Maja Kanop piše: „Gostilne so bile ob vsakem lenštatu ob Dravi. Splavarji so bili njihovi redni gostje. Lesni trgovci so bili pogosto še lastniki gostiln in trgovin, tako da se k njima vrnila večina zasluška splavarjev. Najbolj znane splavarske gostilne ob Dravi so bile v Libeličah gostilna Renat, v Dravogrado Metelko in Pernat, nižje od Dravograda, kjer je mejni kamen med negdanjo Štajersko in Koroško, gostilna Murenhof, na Gortini (Vrata) gostilna Janežič, v Vuzenici Kočevar in Žgajner, v Vuhredu Kogal, v Ožbaltu Lorbek, v Bistrici Pec, gostilna Dobringer v Mariborskih Benetkah, gostilne so bile še v Dupleku, na Ptuju Beli kriz, v Borlu

\footnotetext{
${ }^{146}$ Maja Kanop, Drava - negdaj plovna reka, o.c., 189.

147 Franjo Pahernik, Šajke in splavi na Dravi, o.c., 21-23.
} 
in v Ormožu restavracija pri železniški postaji. V teh gostilnih so najpogosteje jedli golaž, ajmohc, in kruh, juho z nudlči in mesom. Zraven pa je obvezno sodil še štefan vina. ${ }^{\prime \prime 148}$

Osobito su bile poznate i dobro posjećene krčme i prenoćišta u Donjoj Dubravi. Najbliža pristaništu (lenti) bila je gostionica Vrtarić, koju je 1937. preuzeo Slovenac Neslin Seifried (tu je službovala jedno vrijeme i Lojzika Šarman iz Podvelke, a bila je i konobarica kod Rusače). ${ }^{149}$ Najveća i najprometnija bila je krčma, mesnica i prenoćište Rusak, gdje su se odvijali gotovo svi fljojsarski dogovori i veselice. Gostionicu, koju su popularno zvali Rusača, osnovao je polovicom 19. stoljeća Đuro Rusak, a poslove su dobro razvili njegovi nasljednici Mijo (Miška) i Stjepana (Pišta) Rusak. Bila je to prava obiteljska tvrtka koja je držala i prenoćište s nekoliko soba, zatim uhodanu mesnicu, a bavili su se i uzgojem svinja te su poslovali s nekretninama u Donjoj Dubravi. ${ }^{150}$ Kod Rusače su se sklapali poslovi, angažirali i birali splavari, određivali kormanuši i gospodari fljojsa, a održavale su se veselice i razni susreti. Zapravo je Rusača u Donjoj Dubravi splavarima (osobito iz Slovenije) bio drugi dom.

Prema starinskom fljojsarskom običaju, svaki mladi splavar, kada je išao na prvu plovidbu (rajžu), trebao je proći obred krštenja. Dobio je pajdaško ime kojim su ga kolege fljojsari zvali na plovidbama. Obred krštenja priređivao se za sve splavare u dobravskoj krčmi Rusača. U svojem romanu Na splavih slovenski književnik Anton Ingolič, koji je kao mladić i sam plovio na splavima Dravom, piše: „V Dobravi mora biti svagdo, ki prvič vozi kod splavar ali kormanišs, krščen. Tu v gostilni Rusak imamo spravljeno obleko za duhovnika in ministranta in tudi knjigo, kamo se kršteni vpišejo. Cela ceremonija mora biti fanj svečana, kako pri pravem krstu. ${ }^{\prime 151}$ Prigodom krštenja voditelj krsta (,svećenik“) mladog je fljojsara pitao mnoga dvoznačna i smiješna pitanja, a ako nije dobro odgovorio, bio je ili kažnjen ili ismijan. ${ }^{152}$

O gostionici Rusak i obredu krštenja Ivan Vanč Verboten iz Brezna pripovijeda svoje iskustvo: „Ko so prišli v splavarsko gostilno Rusak, je gospodar Šarman

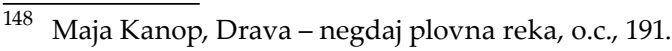

149 Poznate krčme bile su i u Otoku kod Preloga (Lovac), u Kotoribi blizu Mure (Čizmadija) i drugdje. Dragutin Feletar, Hrvoje Petrić i dr., Općina i župa Donja Dubrava, o.c., 101-107.

150 Dragutin Šafar, Dubravska restauracija Rusak nekoć, Dobravske novine, 11, Općina Donja Dubrava, 24. 12. 1998.; Gostionica Rusak radila je sve do 1950-ih godina, kada ju je vodila Stjepanova udovica Marija, sa kćeri Ankom i sinom Dragutinom. Đuro Rusak je potkraj 19. stoljeća sagradio tada velebno zdanje krčme, mesnice i prenoćišta u stilu tadašnjeg historicizma - zgrada postoji još i danas, a u njoj posluje prodavaonica mješovitom robom (vidi fotografiju).

Anton Ingolič, Na splavih, Založila Modra ptica, Ljubljana, 1940., 225-231.

152 Dragutin Feletar, Fljojsari - negdašnji dravski mornari, Meridijani, 176, Zagreb - Samobor, lipanj 2013., 58-65. 


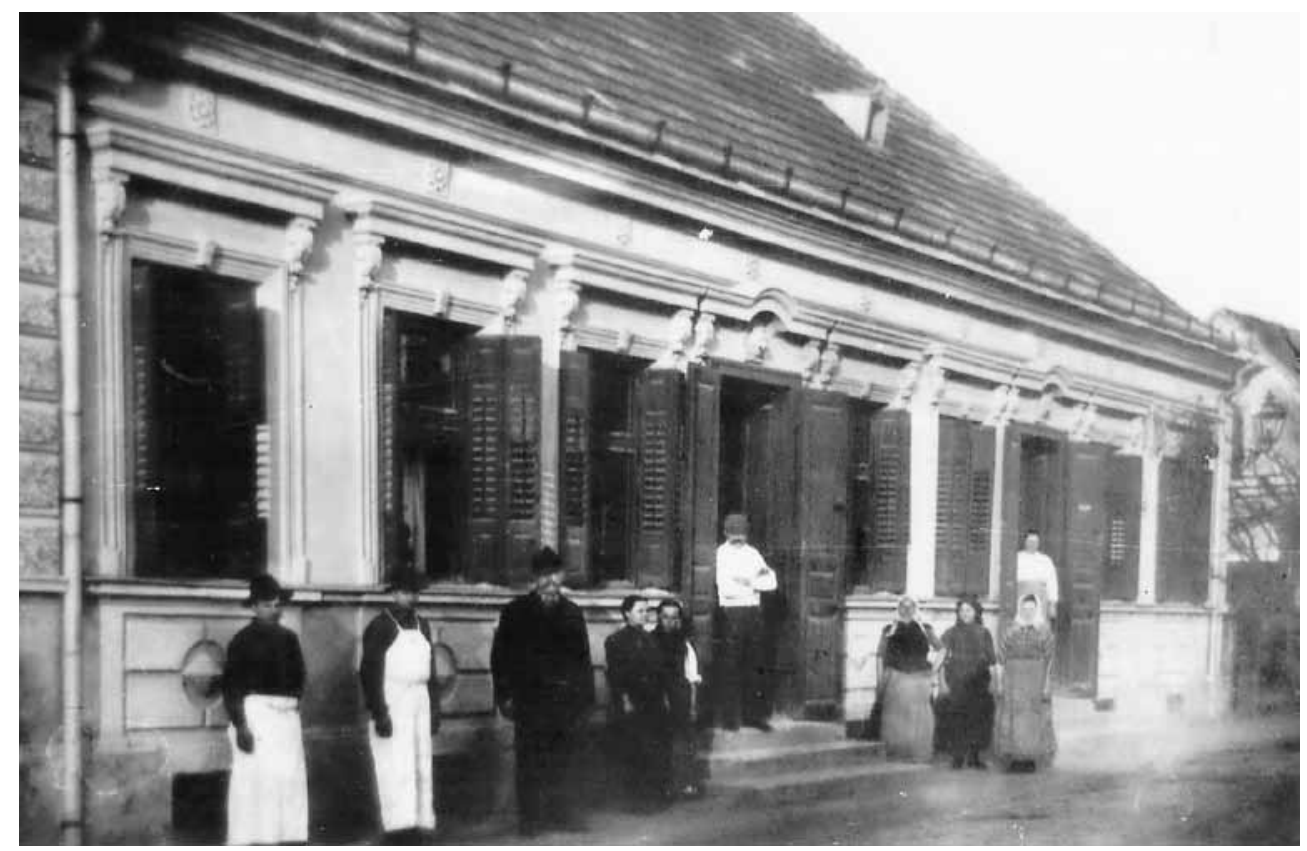

Slika 32. Krčma Rusača u Donjoj Dubravi, u kojoj je obavljano „krštenje“ za sve mlade splavare (foto-arhiv D. Feletara)

začel isplačevati splavarje za opravljeno delo. Medtem so starejši splavarji že pripravljali krsni obred. Kad iznenada so se otprla vrata večje gostilniške sobe: ministranta sta na okrašeno samokolnici pripeljala župnika. Vsi so bili oblečeni, kakor se spodobi za splavarski krst. Župnik je izstopil in povabil Vanča, naj pristopi h krstu. Župnik je stal na sredini, na vsaki strani po ministrant. Desni je imel sa seboj škaf, poln vode, in enega praznega. Levi pa v vsaki roki en bokal, enega praznega, v drugem vino. Župnik je začel postavljati vprašanja, bilo ih je pet, na štiri je novinec pravilno odgovoril, enega pa zgrešil. Za nepravilen odgovor je ministrant vlil liter vode $\mathrm{v}$ prazen škaf. Zadnje župnikovo vprašanje novincu je bilo, ali že biti krščen z vodo ili z vinom. Odgovor je bil, da z vinom. Če bi se odločil za vodo, bi dobil liter vode po glavi, tako pa je bil krščen z vinom. Boter mu je izročil ročno uro, da bo vedel, gda mora stati. Vse je vredu končalo, rešil se je "poganstva“ i postal pravi splavar. Nato je bila splavarska veselica. ${ }^{\text {"153 }}$

153 Ivan Verboten, Peter Macuh, Splavarstvo na Dravi in Donavi, o.c., 204-205; Splavar Miha Viltužnik iz Brezna o krstu kod Rusače u Donjoj Dubravi pripovijeda: „Naj še povem, da so starejši splavari krstili vse tiste, ki smo šli prvikrat na rajžo. Krstili so nas v gostilni. Enega od starejših splavarjev sem prosil, če bi bil moj goten. Starejši splavar, ki je bil za fajmoštra, me je potem vprašal: Kaj moraš naprej narediti, ko prideš flis delat? Odgovoril sem mu, da je treba naprej trte namočiti v Dravi 
Iako je i u godinama pred Drugi svjetski rat trgovina drvom na Dravi i Dunavu još vrlo uspješno funkcionirala, bilo je očito da se tom stoljetnom poslu bliži kraj. Naime, i uz sve dozvole riječne plovidbe iz Osijeka, sve je nesigurnije bilo ploviti na graničnoj Dravi, a kada je i Mađarska ušla u rat, broj plovidbi bitno se smanjio. Čini se da je zadnju trgovačku plovidbu splavima iz doline splavarjev do Vukovara organizirao flosarski gospodar Franc Šarman iz Podvelke, a na toj zimskoj rajži sudjelovao je i tada već kormanuš, Ivan Vanč Verboten. Početak plovidbe iz Javnika kod Ožbalta bio je početkom veljače 1941., a splavi su ušle u vukovarsku luku 6. travnja 1941., dakle neposredno pred bombardiranje Beograda. Slovenski splavari proživjeli su pravu kalvariju na povratku u Brezno. ${ }^{154}$ Tvrtka Borka Eugena Kaufmanna iz Donje Dubrave trgovala je drvnom građom sve do 1943., pa postoje indicije da je još i početkom Drugog svjetskog rata iz dobravske lente isplovio pokoji fljojs prema Vizvaru i Osijeku. Nakon rata tradicionalno i nekad vrlo uspješno splavarstvo na Dravi više se nije obnovilo.

\section{ZAKLJUČAK - DRAVA KAO TURISTIČKI RESURS}

Kroz prošlost, sve do Drugoga svjetskoga rata, prometna funkcija rijeke Drave bila je jedan od glavnih nositelja gospodarskog života priobalnog stanovništva. To se prvenstveno odnosi na šajkaštvo i splavarstvo, koji su zapošljavali (u cijelom lancu) najviše ljudi i donosili najveće prihode. Ta je djelatnost bila osobito važna za slovensku i gornju hrvatsku Podravinu, gdje je rijeka, zapravo, određivala i vodila stil života ovdašnjeg stanovništva. U svojem razvoju, splavarstvo na Dravi imalo je svoje sinusoide, a osobito uspješno razvilo se od vremena barokne obnove u 18. stoljeću pa do pred Drugi svjetski rat.

Šajkaštvo i splavarstvo na Dravi ostavilo je dakle golem i upečatljiv zapis u narodnom sjećanju. Taj je povijesni zapis ostao u pridravskim ljudima kao trajna vrijednost, a tinja još i danas. Bez obzira na to što Drava više ne donosi "starinske darove“, što ponekad ošine priobalje kakvom poplavom, ona je za lju-

Potem je spet vprašal: $S$ čim hočeš biti krščen? Z vodo ali vinom? Odgovoril sem mu, da $\mathrm{z}$ vinom. Potem mi ga je malo zlil na glavo. Tisto vino, bilo ga je pet litrov, je kupil goti. Potem so se nam pridružili še drugi in so tudi dali za pijačo. Mene so krstili leta 1927." Ivan Verboten, Peter Macuh, Splavarstvo na Dravi in Donavi, o.c., 233.

Ivan Verboten, Peter Macuh, Splavarstvo na Dravi in Donavi, o.c., 211-217; Na Mariborskim Benetkama, gdje je bio lent za splave i šajke, bila je poznata gostionica Dobringer, a vlasnik je bio i veletrgovac drvom. Krescencija Bosilj (Cencika Šarman) sjeća se Dobringerove krčme: „V tej gostilni je bilo vedno hrupno in vedno je dišalo po golažu, vampih ali po kakšnih drugih čebulovi košti. Tisti flosarji, ki so bili premožnejši in so si od doma prinesli popotnico, so se ustavili v gostilni, si privezali dušo $z$ obilno malico, tisti, vernejši, ki so šli na pot z aro, pa so si nakupili nekaj hrane za po poti." Silva Pečar Vanjanovič, Zgodbe s pridikom zgodovine, Drava nekoč in danes, Založba Obzorja, Maribor, 2000., 268-269. 


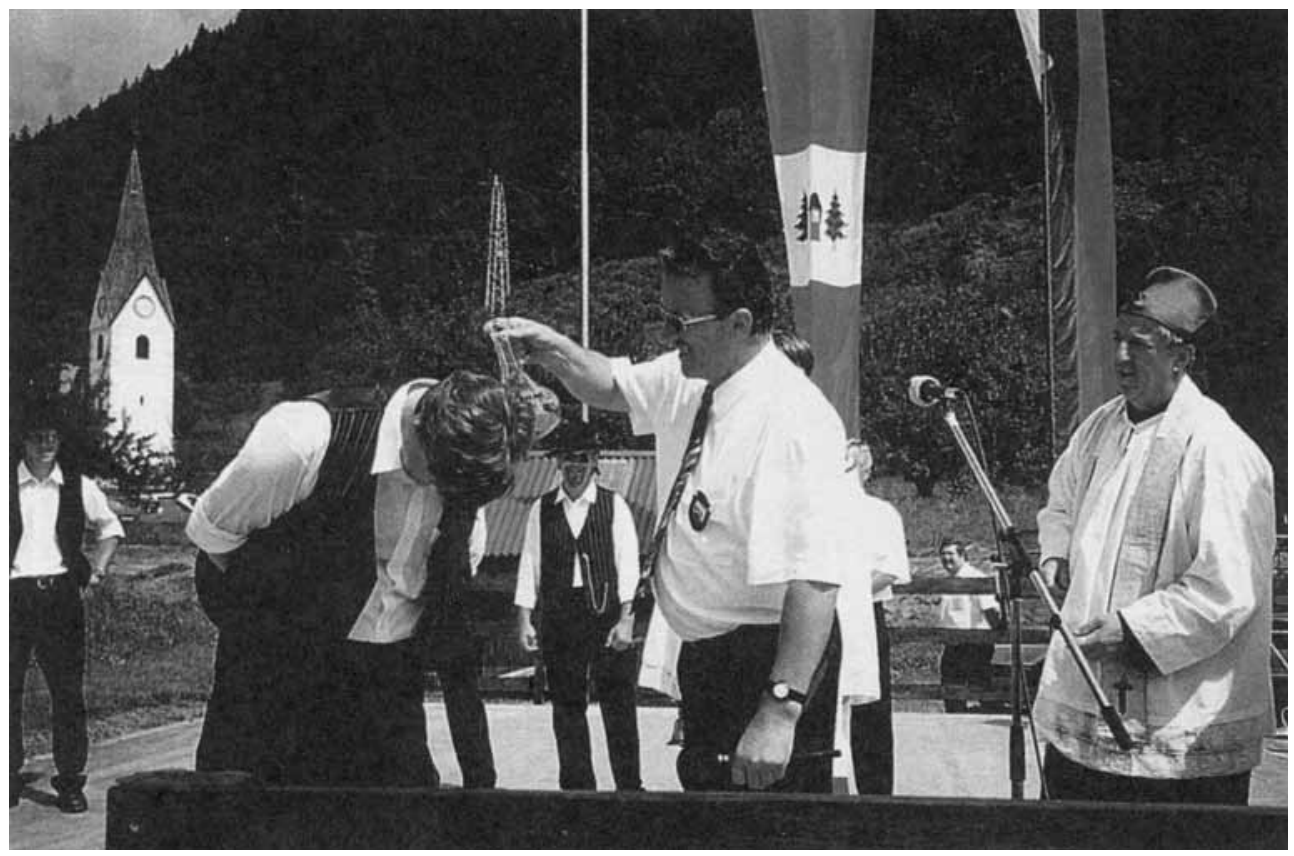

Slika 33. Detalj iz obreda splavarskog krsta u Breznom 1997. godine (Drava nekoč in danes, 2000.)

de uz rijeku ostala kultna „naša“ Drava. U ozračju današnjeg modernog života, privređivanja i odnosa prema prirodi, Drava opet zauzima sve važnije mjesto u ukupnom životu ne samo porječja nego i priležećih država. Drava zapravo nikad nije prestala donositi „darove“ za gospodarstvo i život ljudi, pogotovo u pogledu energetskog iskorištavanja i navodnjavanja. Danas, pak, Drava zahtijeva mnogo suptilniji odnos ljudi prema rijeci kako bi se očuvale njezine prirodne (ekološke) vrijednosti te snažnije razvijali turizam i rekreacija. U tom smjeru osobito je važno djelovanje Hrvatske i Mađarske, jer tok Drave od Donje Dubrave do Aljmaša danas pripada među prirodno najočuvanije i najatraktivnije u Europi.

U slovenskom i gornjem hrvatskom toku Drava je dobrim dijelom prirodno „izgubljena“ rijeka. To se odnosi i na tok rijeke u Austriji, gdje je izgrađen velik broj hidroelektrana i akumulacija. U Sloveniji je na Dravi izgrađeno 8 i u Hrvatskoj još 3 hidroelektrane: HE Fala (puštena u pogon 1918.), HE Dravograd (1945.), HE Mariborski Otok (1948.), HE Vuzenica (1956.), HE Vuhred (1957.), HE Ožbalt (1959.), HE Zlatoličje (1968.) i HE Formin (1975.) te HE Varaždin (1975.), HE Čakovec (1982.) i HE Dubrava (1989.). Iako postoje vrlo ozbiljni planovi za izgradnju elektrana i nizvodno od ušća Mure (primjerice, HE Molve I. i II., pa nizvodno 
sve do Osijeka!), nadajmo se da će prevladati razum i briga za prirodu te da se na Dravi neće izgraditi više nijedan energetski objekt. ${ }^{155}$ Izgradnjom hidroelektrana ozbiljno je na rijeci narušena prirodna ravnoteža, ali atraktivnost Drave nije posve izgubljena. I akumulacije, pa stari dravski tokovi i rukavci te druge prirodne vrijednosti, čine i ovdje Dravu atraktivnom. To se odnosi i na tri velike akumulacije u Hrvatskoj: Ormoško jezero (oko $3 \mathrm{~km}^{2}$, koje je i veliki ornitološki rezervat), Varaždinsko jezero $\left(10,5 \mathrm{~km}^{2}\right)$ i osobito Dubravsko jezero (sa $16,6 \mathrm{~km}^{2}$ to je najveća umjetna akumulacija u Hrvatskoj.). ${ }^{156}$

Za turističko-gospodarsku valorizaciju rijeke Drave postoje dvije osnovne pretpostavke: brojne ekološko-krajobrazne vrijednosti te duga tradicija starih dravskih zanimanja - prvenstveno zlatarstva i splavarstva. Te vrijednosti nastoje se u svim državama uz Dravu što više čuvati i zaštititi. Uz „divlju“ rijeku i milovidne pejzaže, uz Dravu samo u Sloveniji živi oko 270 vrsta ptica (blizu 40 je ugroženo), 50 vrsta riba, 40 vrsta zmija itd., a veliko je i bogatstvo biljnoga svijeta. Zato je Drava i u Sloveniji zaštićena kao dio područja Natura 2000, a tu se provodi i projekt Europske unije Obnova riječnoga ekosustava niskoga dijela Drave u Sloveniji (2012. - 2018.). Za zaštitu Drave važan je i zakon Načrt upravljanja voda na vodnem območju Drave in Donave za obdobje 2016.-2021. Uz to, Slovenija je potpisala važan međunarodni projekt -Konvencija o zaštiti rijeke Drave - koji države obvezuje da trajno vode brigu o zaštiti ekosustava te rijeke. ${ }^{157}$

Ekosustav Drave u Hrvatskoj još je znatno veći, bujniji, raznovrsniji i atraktivniji negoli u Sloveniji. Uz pravo bogatstvo nekoliko stotina vrsta ptica i riba (među kojima ima i rijetkih vrsta, ali i ugroženih), tu žive i ugrožene vrste vaskularne flore, zaštićene vrste sisavaca, zaštićene vrste leptira, vretenaca, gljiva itd. Uz Dravu živi i atraktivan svijet divljih i poludivljih životinja, a velika je i raznovrsnost biljnoga svijeta (pogotovo bjelogorice). $\mathrm{K}$ tomu svemu valja pribrojiti prekrasne pridravske pejzaže, razgranati tok Drave i druge prirodne vrijednosti. Stoga priobalno stanovništvo i država Hrvatska imaju veliku zadaću i odgovornost ekološki zaštititi cjelokupno područje Drave. Nakon što su u razdoblju od 1960-ih godina do danas zaštićeni najatraktivniji dijelovi krajolika, u veljači 2011. Hrvatska je proglasila Regionalni park Mura-Drava, koji se proteže na

\footnotetext{
155 Marijan Šman, Drava - vir električne energije, Drava nekoč in danes, Založba Obzorja, Maribor, 2000., 370-425; Dragutin Feletar, Energija u sustavu održiva razvoja - hidroelektrane na Dravi, Meridijani, 145, Zagreb-Samobor, 2010., 58-65.

156 Velike akumulacije postale su „raj“ za ptice, a raste i ihtiološka vrijednost Drave. Dragutin Feletar, Energija u sustavu.., o.c., 59-62.

157 Matija Zorn, Gospodarska vloga reke Drave v Sloveniji - od plovnosti reke do hidroenergetske izrabe, Podravina, 33, Meridijani, Koprivnica, 2018., 60-62.
} 
87.680 ha od slovenske granice do Dunava. ${ }^{158} \mathrm{U}$ međunarodnim programima i projektima, područje Drave u Hrvatskoj sastavni je dio Nature 2000, ali i izuzetno važnog UNESCO-ova programa Čovjek i biosfera, odnosno na području Drave u Hrvatskoj i Mađarskoj proglašen je Biosferni rezervat Mura-DravaDunav (2012.). ${ }^{159}$ U zaštiti niskih dravskih poloja još su dalje otišli Mađari, koji su područje od Legradske gore (Belezna) do Baje na Dunavu još 1996. proglasili nacionalnim parkom kao najvišom razinom zaštite prirode. Duna-Dráva nemzeti park po protezanju je najduži u Europi, a proteže se uskim pojasom uz Dravu i dijelom Dunava na oko 50.000 ha. ${ }^{160}$

Za turističko-rekreativnu valorizaciju Regionalnog parka Mura-Drava posebno su vrijedni njegovi najatraktivniji dijelovi, a to su posebno zaštićena područja. Proces zaštićivanja počeo je još 1960-ih godina, a u tom je procesu najznačajnije bilo proglašenje Parka prirode Kopački rit u jugoistočnoj Baranji. Park prirode Kopački rit obuhvaća $231 \mathrm{~km}^{2}$ jezerskog i zamočvarenog područja između Drave i Dunava, u kojem je dosad konstatirano više od 2.000 bioloških vrsta. Godine 1993. Kopački rit uvršten je u popis vlažnih područja od međunarodnoga značenja, sukladno tzv. Ramsarskoj konvenciji. ${ }^{161}$ Zahvaljujući Kopačkom ritu, ali i drugim atraktivnostima i punudi, Baranja se razvila u jedno od najaktivnijih turističko-rekreativnih područja hrvatskoga kontinentalnog turizma.

I ostala posebno zaštićena područja i spomenici prirode u Regionalnom parku Mura-Drava vrlo su važni za potencijalni razvoj turizma. Tako je kao značajni krajobraz proglašeno šire područje uz Muru u istočnom Međimurju (2001.), spomenik parkovne arhitekture jest perivoj uz dvorac Križovljangrad (1962.), park-šuma je Dravska šuma kod Varaždina (2001.), a spomenikom prirode proglašena su stabla bijele topole kod Varaždina (2001.), dok su spomenikom prirode proglašena stabla hrasta lužnjaka kod šumarije Repaš (1997.) te skupina stabala Noskovačka Dubrava u virovitičkom kraju (1969.). Prirodno vrlo vrijedno jest i područje posebnog zoološkog rezervata Veliki Pažut na sutoku Mure u Dravu (1998.), značajnim krajobrazom proglašena su pridravska poručja u Križnici (2001.), Čambini (1999.), Jelkušu (2001.) i Širinskom Otoku (2001.) te močvarno stanište Vir (2001.), dok je područje Podpanja kod Donjeg

\footnotetext{
158 Regionalni park Mura-Drava proteže se uz Muru u dužini od 83 km, a uz Dravu u dužini od 323 km (od slovenske granice do Dunava). Dragutin Feletar, Regionalni park Mura-Drava, Meridijani, 155, Samobor, 2011., 24-25.

159 Dragutin Feletar, Regionalni park Mura-Drava, o.c., 26-27.

160 Geografska karta Duna-Drava nemzeti park, 1:60000, Penlus, Szentendre, 2002.

161 Ramsarska konvencija je Konvencija o vlažnim područjima od međunarodnog značenja, osobito kao staništa ptica močvarica. Park prirode Kopački rit, Bilje, 2015., prospekt.
} 
Miholjca proglašeno posebnim rezervatom (1998.). Navedenim prirodnim vrijednostima u području Regionalnog parka Mura-Drava valja pribrojiti još barem 50-ak područja i lokaliteta koji pripadaju Hrvatskoj ekološkoj mreži ili su međunarodno važna područja za ptice. ${ }^{162}$ Te prirodne vrijednosti za razvoj turizma i rekreaciju nastoje iskoristiti sve lokalne samouprave uz Dravu, a (uz Baranju) dosad najviše uspjeha ima Međimurska županija (posebice uz Muru). Cjelovitija valorizacija prirodnih vrijednosti Mure i Drave, kao važnog faktora za razvoj turizma, tek treba uslijediti i u tom resursu kriju se velike nade za gospodarski i društveni razvoj Pridravlja.

Iznesena konstatacija osobito vrijedi i za korištenje još jednog značajnog turističkog resursa Pridravlja, a to je tradicija starih dravskih zanimanja. Atraktivnost starinskog mlinarstva (vodenice), ispiranja zlata, prijevoza brodom (kompom), sportskog ribolova, lovstva, rekreativnog biciklizma uz rijeku, te osobito šajkaštva i splavarstva (fljojsarstva), predstavlja turističku vrijednost koja se može značajnije utkati u gospodarski razvoj ovih krajeva. Ta tradicija još živi u priobalnom narodu, samo treba inicijative, razvojnih programa i ulaganja kako bi se ona pretvorila u turističku valorizaciju. Na tomu se, doduše, uvijek i nešto radilo, ali uglavnom nedovoljno i tek na razini društvenih akcija. Tek u zadnja dva desetljeća razvoj turizma i rekreacije, baziranih i na resursima Drave i Mure, dobiva organiziranije oblike, a ostvaruju se i manji uspjesi.

Uz bezbrojne priče s Drave, tradiciju splavarstva i splavarskoga života najprije su, nakon naprasnog prekida te djelatnosti 1941., pronosili sami splavari, stari dravski mornarski vukovi., a potom pak njihova djeca. U nekim mjestima, poput Brezna i Podvelke, Mariborskih Benetki, Dupleka, Dravograda, Vuzenice ili Donje Dubrave, starinski život na Dravi prerastao je u legendu. Drava stalno zove na svoje virove i produjine, a sve više ljudi (i ne samo iz Pridravlja) odzivlje se tom zovu. Ili kako bi rekli Slovenci iz doline flojsarjev: „Dravska dolina vabi

$\overline{162}$ Na popisu Hrvatske ekološke mreže kao važna područja za divlje svojte i stanišne tipove koji pripadaju Regionalnom parku Mura-Drava navedeno je sljedeće: livade Kopačkog rita, šume vrba i topola Noskovačkog vrbaka, Predrijevački vrbak, šume bijele vrbe Noskovačkog vrbaka, šire područje Drave kod Donjeg Miholjca i Valpova, šire područje Mure u Međimurju, šuma kod Kotoribe, nalazište crnaste sase kod Totovca u Međimurju, ribnjaci kod Donjeg Miholjca, Podpanj, dravske šume Repaš i oko njega, Veliki Pažut, ušće Plitvice i Bednje, Čambina, Ješkovo, rukavac kod Đelekovca i zaštićene livade leptira Zovje, Lepa Greda, Širinski otok, Jelkuš, Križnica, Bakovci, Osredek, Budakovac, Predrijevačka bara, Noskovci, rukavac kod Križovljangrada, stari tok Drave kod Varaždina, šuma Murščak, Lendava-Stari Gradac, županijski kanal Gornje Barje-Zidina, sopjanska bara te jezero Šoderica. Kao međunarodno važna područja za ptice, uz Kopački rit, još su: srednji tok Drave od Terezinog Polja do Donjeg Miholjca, sve dravske akumulacije (umjetna jezera, šoderice, ribnjaci), gornji tok Drave od Donje Dubrave do Terezinog Polja, te donje Podravlje i Podunavlje. Dragutin Feletar, Regionalni park Mura-Drava, o.c., priležeća karta parka. 


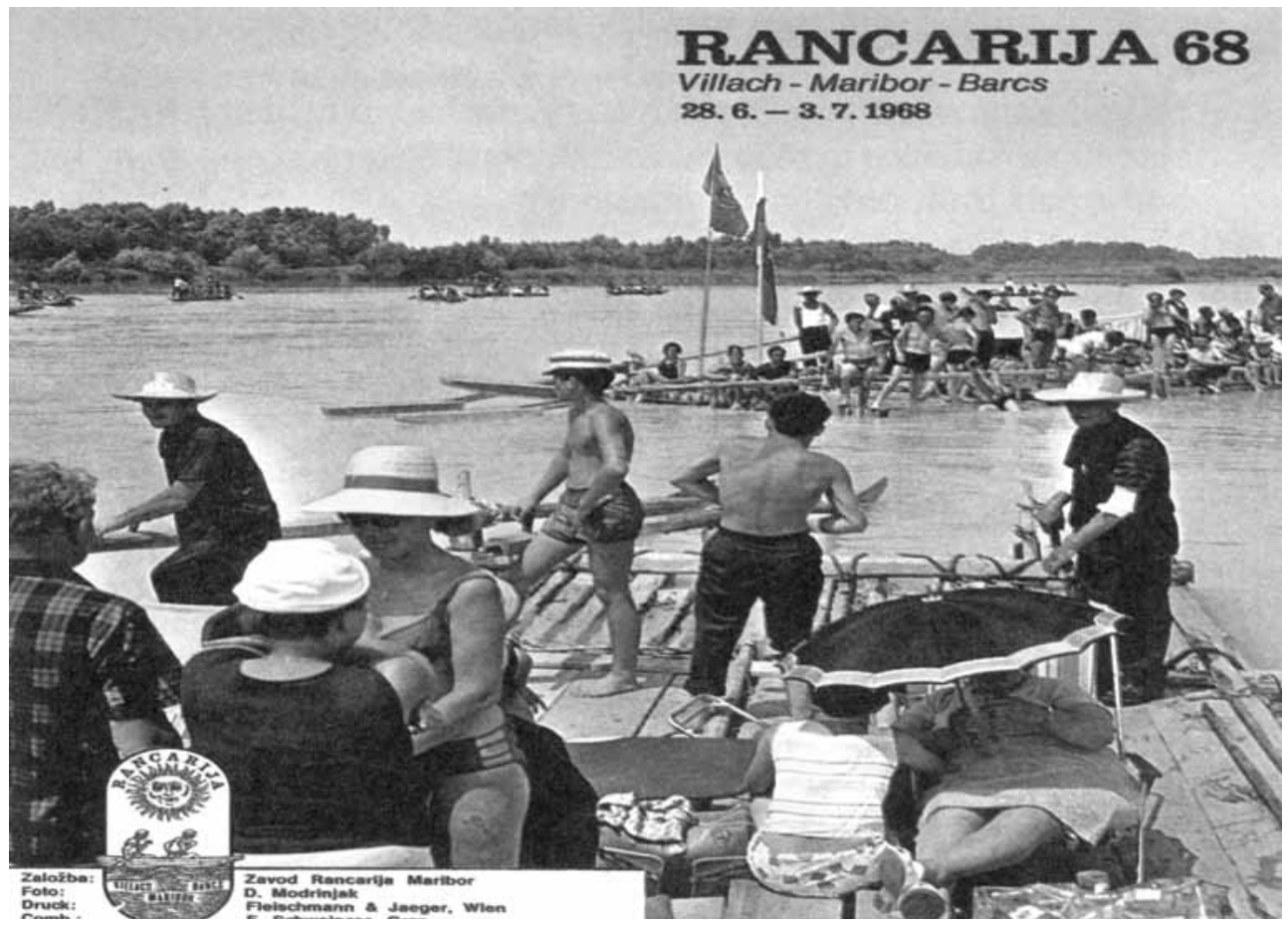

Slika 34. Detalj s turističke akcije Rancarija 1968. godine (Večer, Maribor)

spet na splav“. 163 Tako su se splavari na Pohorju sastajali već u vrijeme Drugoga svjetskoga rata, a obnova organizirane plovidbe i obnavljanje uspomena na splavarstvo započelo je od 1960-ih godina - i u Sloveniji i u sjeverozapadnoj Hrvatskoj.

Stare dravske snove najviše je probudila društveno-turistička akcija, koju je pod nazivom Rancarija ${ }^{164}$ organizirao 1967. i 1968. mariborski dnevnik Večer. Na Rancariji 1967. plovilo se od Maribora do Donje Dubrave (tada još nisu puštene u pogon hidroelektrane u Zlatoličju i Forminu). Na put dug $160 \mathrm{~km}$ pošla su dvije prave splavi (veličine $30 \mathrm{~m}$ puta $5 \mathrm{~m}$ ) i 40 čamaca (ranca, čona). Koliko je zanimanje probudila ta akcija kod stanovništva uz Dravu (i drugih postjetitelja), govori podatak da je uz rijeku i na 12 priredbi koje su tada organizirane od Maribora

\footnotetext{
$\overline{163}$ Ivan Verboten, Peter Macuh, Reka - ki bo spet življenje, Drava nekoč in danes, Založba Obzorja, Maribor, 2000., 434.

164 Ime turističke akcije dolazi od naziva dravskog čamca, koji Slovenci zovu ranca. U organizacijskom odboru bili su ljudi iz svih priležećih općina u Sloveniji i Hrvatskoj (pa tako i autor ovih redaka, koji je tada radio kao novinar u Čakovcu).
} 


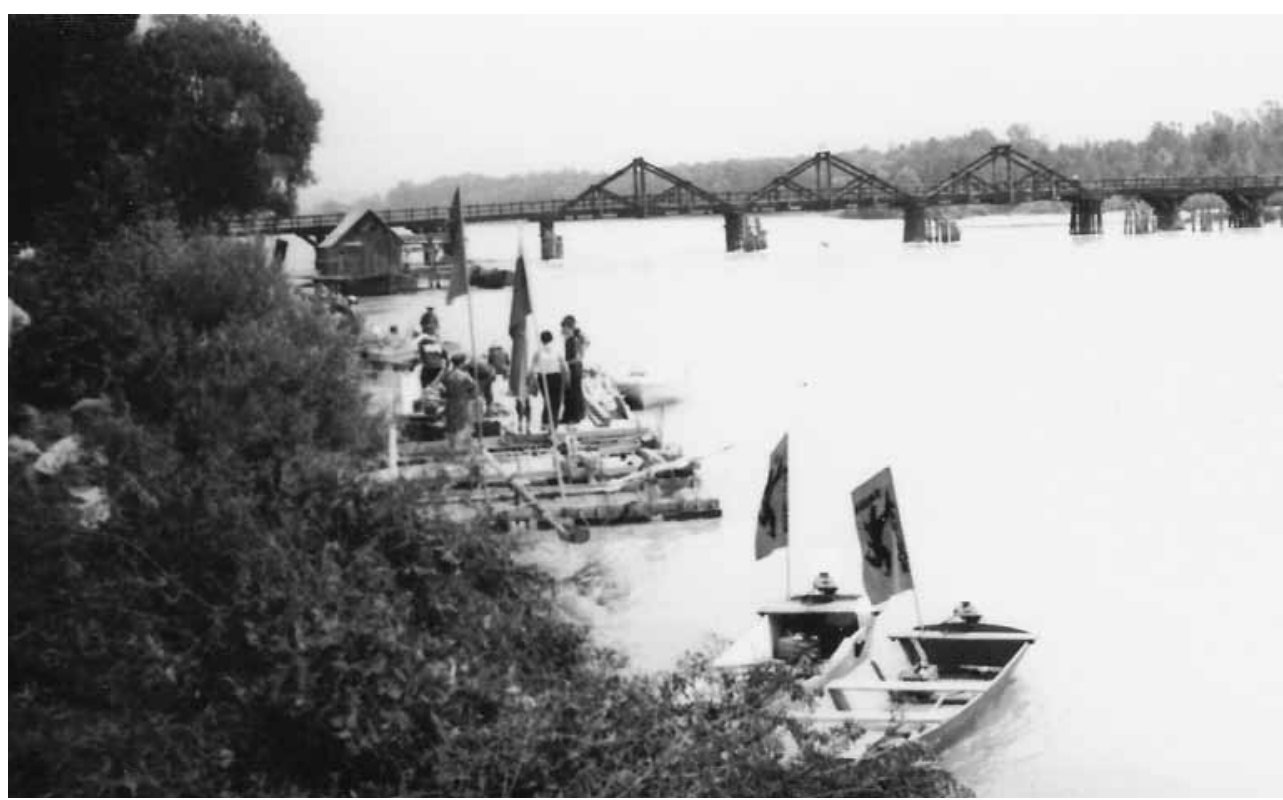

Slika 35. Čamci (rance) vezani uz letu u Donjoj Dubravi - na Rancariji 1967. godine (snimio D. Feletar)

do Donje Dubrave bilo nazočno više od 200.000 ljudi! ${ }^{165}$ Na poletu tog uspjeha turistička akcija Rancarija 1968. bila je velebna: Dravom i kopnom na plovidbu ili putovanje krenulo se od austrijskog Beljaka, a vozilo se sve do mađarskog Barča. Na Dravi su opet plovili pravi fljojsi te više od stotinu čamaca, a na cestama uz rijeku pratilo ih je još 20-ak autobusa. Održano je više od 150 priredbi i okupljanja, a manifestaciju je pratilo oko 500 novinara. ${ }^{166}$ Duh starih splavara iz Drave je ušao u ljude.

Sljedećih godina, a posebice nakon 1990-ih, u mnogim mjestima sa splavarskom tradicijom uz Dravu osnivaju se udruge i društva te se organiziraju društveno-turističke akcije koje gaje tradiciju starinskih dravskih zanimanja. Primjerice, Turističko društvo Maribor (i općina Rotovž) na Mariborskim Benetkama

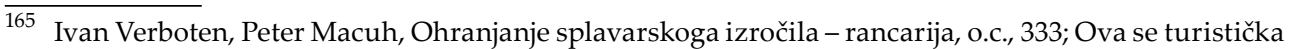
akcija zvala i Karavana prijateljstva. Čakovečki list Međimurje o tomu piše: „U prisustvu više od 15.000 građana Maribora, u subotu, 1. srpnja 1967., krenula je na put ovogodišnja „Karavana prijateljstva“. Uz pratnju dvadesetak motornih čamaca i buku desetak aviona Mariborskog aero-kluba, na put "rancama“ dug $160 \mathrm{~km}$, s krajnjom točkom u Donjoj Dubravi, krenulo je više od tisuću domaćih i stranih turista (dio i kopnenim putom)". Među sudionicima je bio i čamac Donjodubravčana, među kojima je plovio i autor ovoga članka, sa suprugom. Dragutin Feletar, Dravom 160 km, Međimurje, Čakovec, 12. 7. 1967.

166 Ivan Verboten, Peter Macuh, Ohranjenje splavarskoga izročila - rancarija, o.c., 333-340. 
organiziraju atraktivne priredbe Mariborski lent (odnosno Festival Lent), u okviru kojeg se prikazuje i splavarski krst, koji se u prošlosti održavao u donjodubravskoj krčmi Rusak. ${ }^{167}$ Priredbe bazirane na splavarskoj tradiciji održavaju se i u Dravogradu (gdje je vrlo aktivan i nautički klub), Vuzenici, Breznu i drugim nekadašnjim splavarskim pristaništima.

Posebice su atraktivne splavarske svečanosti koje svake godine u Dupleku organizira Glavni štab Dupleške mornarice. Te se priredbe, s poznatom utrkom rancama, u Dupleku organiziraju već gotovo četiri desetljeća, uz sve veću popularnost. ${ }^{168}$ Splavarska tradicija kroz turističko-društvene priredbe osobito je živa u Breznom, Podvelki i Javniku. Tu se tijekom cijele sezone organiziraju plovidbe na improviziranoj splavi i na čamcima dijelom Drave te brojne priredbe, među kojima je i Splavarski krst. Zahvaljujući nasljednicima obitelji starih splavarskih kormanuša Šarman, u Javniku je osnovan i specijalizirani splavarski muzej, a djeluje i flosarska krčma. Uz obalu je vezana i improvizirana dravska splav, na kojoj se organiziraju brojne priredbe, pa i svadbe. Uz pomoć Pokrajinskoga muzeja iz Slovenj Gradeca, u obiteljskoj kući Šarman uređen je 2001. Splavarski muzej, koji vodi unuk slavnog dravskog kormanuša, kralja Drave Franca Šarmana - Franjo Šarman. Muzej prezentira pravo bogatstvo podataka o splavarstvu, a prikupljen je i velik broj originalnih splavarskih alatki i predmeta iz života flosara. Turističku ponudu upotpunjava susjedna gostilna Šarman, koja nudi jela i pića spremljena na splavarski način. ${ }^{169}$ Te i druge aktivnosti već su danas učinile slovensku dolinu flosarjev važnom destinacijom za razvoj kontinentalnog turizma. Matija Zorn navodi da je od proljeća do jeseni 2017. tim dijelom Drave na splavima i čamcima prevezeno više od 10.000 turista. ${ }^{170}$

I općine na Dravi u Hrvatskoj, posebice u sjeverozapadnom dijelu, žele ići tim putom. Krenulo se od organiziranja brojnih biciklističkih ruta uz Dravu, ali na rijeci je i sve više plovila, pa i starinskih čamaca. Turističku valorizaciju Drave, temeljenu na starinskim zanimanjima, podupiru država i lokalna samouprava, ali i fondovi Europske unije. U mjestima uz Dravu osnivaju se i korisne društvene udruge, koje gaje tradiciju dravskih splavara, zlatara i mlinara. Tako su vrlo aktivni nautički klubovi u Varaždinu i Prelogu, a u Donjem Vidovcu osnovano je posebno društvo dravskih zlatara, koje ovih godina uređuje speci-

\footnotetext{
$\overline{167}$ Ta se mariborska priredba obdržava svake godine još od 1985. ljeta. Ivan Verboten, Petar Macuh, Ohranjenje splavarskega izročila - rancarija, o.c., 344-347.

168 Ivan Verboten, Peter Macuh, Reka - ki bo spet življenje, o.c., 438-441.

169 Splavarski muzej Javnik, Založila Občina Podvelka, prospekt, 2001.; Gostilna Šarman, prospekt, Splavarski pozdrav ju-hu, 2012.

170 Matija Zorn, Gospodarska vloga reke Drave.., o.c., 60-61.
} 


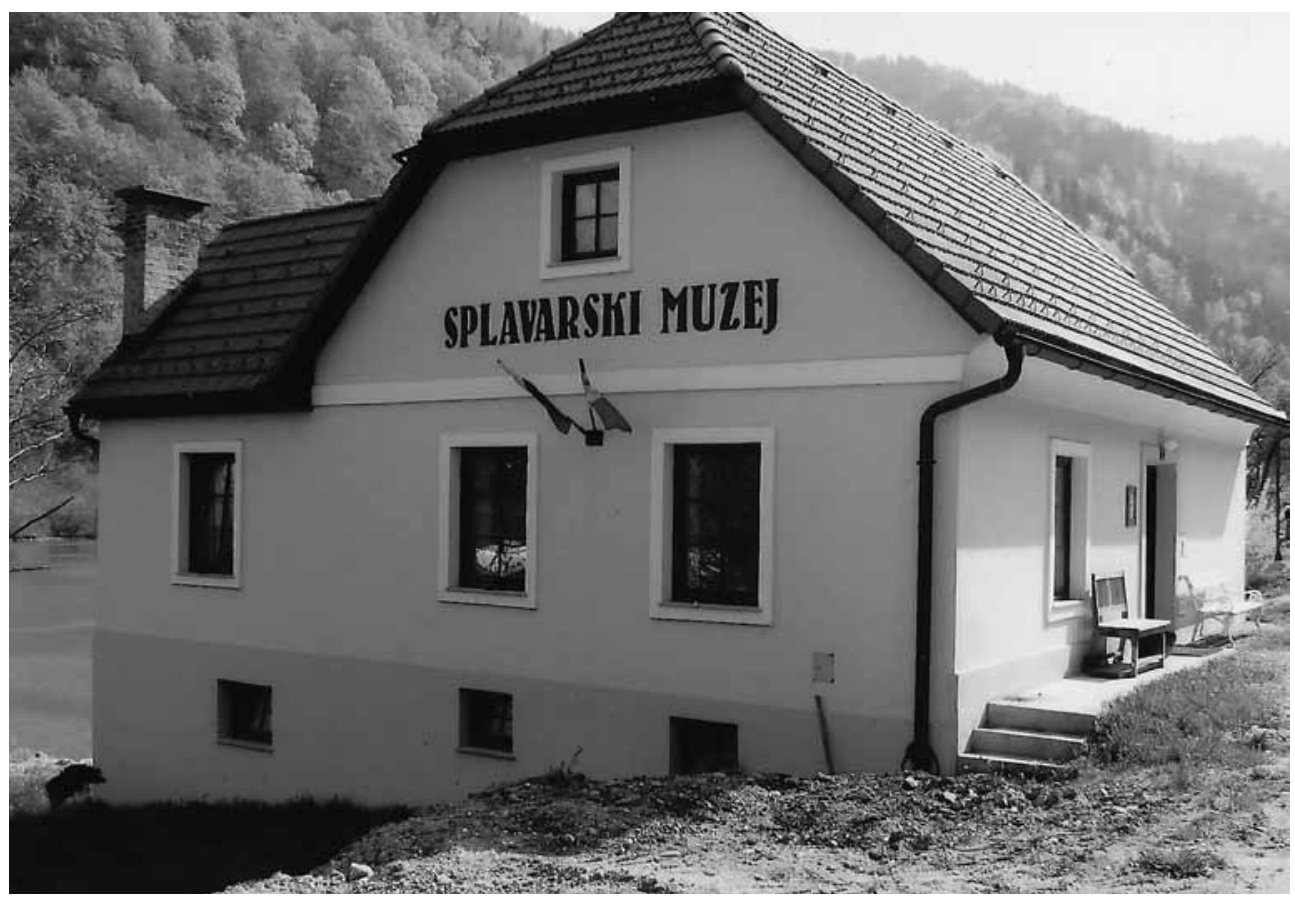

Slika 36. Obiteljska kuća Šarman u Javniku (Podvelka) preuređena je u Splavarski muzej (snimio P. Feletar, 2015.)

jalizirani muzej ispirača zlata na Dravi i Muri. U Donjoj Dubravi, starom fljojsarskom središtu, djeluje ekološka udruga SENJAR, koja prvenstveno brine o zaštiti rezervata Veliki Pažut na sutoku Mure u Dravu. U tome mjestu sjećanje na stare splavare nikad nije prekinuto, a 2005. osnovan je i Nautički klub Fljojsar, koji okuplja velik broj poklonika Drave. Klub je izgradio drveni društveni dom, koji pliva na skeli kod nekadašnje dravske lente, te raspolaže malom flotom dravskih čamaca (čona). Organiziraju se spustovi Dravom, pa i do Aljmaša (2007.), Vukovara (2010.) i Iloka (2012.) te već deseta smotra dravskih plovila s natjecanjem u veslanju dravskim čonima koja pobuđuje i veliko zanimanje turista. Dobravski fljojsari plove i Murom, te uz pomoć općinske zajednice predstavljaju sjeme razvoja turizma na Dravi i Muri. ${ }^{171}$

Duga tradicija splavarstva, iako je kao gospodarska djelatnost prekinuta prije više od 80 godina, stanovništvu uz Dravu (i Muru) nudi nove mogućnosti i izazove za razvoj. Sudeći prema klimi i aktivnostima koje se poduzimaju, duh starih splavara s Drave živjet će još puno ljeta.

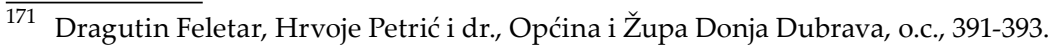




\section{Izvori i literatura}

ANDROIĆ, Mirko (1972.), Varaždinski trgovac Vinko Perger, Kaj, 10, Zagreb, 65-70. ANDROIĆ, Mirko (1983.), Neke značajke razvoja Varaždina u 18. stoljeću, Varaždinski zbornik, HAZU, Varaždin, 209-216.

ANDROIĆ, Mirko (2009.), Ekonomika srednjovjekovnog grada Varaždina, Državni arhiv, Varaždin.

BARTOLIĆ, Zvonimir (1964.), Donja Dubrava u svojoj historiji, legendi i stvarnosti, Međimurje, Čakovec, 29. 7. 1964.

BARTOLIĆ, Zvonimir (1993.), Povijesna pripovijest o Dobravi, Dobravske novine, 1, 10. srpnja 1993.

BAŠ, Angelos (1972.), Ob dravskih splavarjih, Slovenski etnograf, 143-156, Ljubljana. BEDEKOVIĆ, Josip (2017.), Knjiga o sv. Jeronimu, Iliriku i Međimurju, HAZU i dr., ur. Dragutin Feletar, Zagreb - Čakovec (original na latinskom objavljen 1752.).

BERCHTOLD-OGRIS, M. (2001.), Iskoriščanje Drave in njenih pritokov, Die Drau ist eine Frau / Drava je svoja frava, Celovec, 22-36.

BIĆANIĆ, Rudolf, Doba manufakture u Hrvatskoj i Slavoniji (1750.-1860.), Izdavački zavod HAZU, Zagreb, 1951.

BLAŠKOVIĆ, Vladimir (1976.), Osobitosti Drave i naše granice u Podravini, Podravski zbornik, 2, Koprivnica, 140-146.

BREGOVIĆ, Antica (2004.), Prirodne značajke rijeke Drave do sredine 20. stoljeća, Život uz Dravu nekad i danas, Gradski muzej, Zavod za znastveni rad HAZU, Varaždin, 59-74.

BREGOVIĆ, Antica, ur. (2004.), Život uz Dravu nekad i danas, katalog, Gradski muzej, Varaždin.

BRENCE, Andrej (1996.), Ptuj z okolico, Ptuj.

BREZNO i Podvelka, Bogata zgodovina dveh majhnih krajev (2012.), Podvelka.

BUNJAC, Borka, BUNJAC, Vladimir, JAHN, Julijana, MATOTEK, Višnja, PUZAK, Ivana, ŠESTAK, Mario (2003.), Pregled povijesti Međimurja, Povijesno društvo Međimurske županije, Čakovec.

CIMERMAN, Franjo (1998.), Obrt u Međimurju, (Splavari, lađari, šajkaši), Čakovec. CURK, Jože (1985.), Dravograd s okolico, Ljubljana.

ENTNER, B. (2001.), Dravsko splavarstvo, Die Drau ist eine Frau / Drava je svoja frava, Celovec, 164-181.

FELETAR, Dragutin (1965.), Donjodubravski fljojsari, Međimurje, Čakovec, 9. rujna 1965.

FELETAR, Dragutin (1967.), Dravom 160 km, Međimurje, Čakovec, 12. srpnja 1967. 
FELETAR, Dragutin (1968.), Fljojsarenje na Dravi, Kaj, 1, Zagreb, 65-67.

FELETAR, Dragutin (1968.), Iz povijesti Međimurja. Slike iz hrvatske povijesti i drugi feljtoni, Ogranak Matice hrvatske, Čakovec.

FELETAR, Dragutin (1968.), Splavi s neobičnim teretom, Međimurje, Čakovec, 17. 4. 1968.

FELETAR, Dragutin (1971.), Legrad, KPD Zrinski, Čakovec.

FELETAR, Dragutin (1976.), Splavari i zlatari na Dravi, Podravski zbornik, 2, Koprivnica, 116-131.

FELETAR, Dragutin (1988., 1989.), Podravina, Pregled povijesti do 1945. godine, Muzej grada, Koprivnica.

FELETAR, Dragutin (1996.), Pregled povijesti naselja Donji Vidovec, Mjesto i župa Donji Vidovec, ur. Ivan Zvonar, Općinsko poglavarstvo, Donji Vidovec, 9-37.

FELETAR, Dragutin (2010.), Energija u sustavu održiva razvoja, Hidroelektrane na Dravi, Meridijani, 145, Samobor, svibanj 2010., 58-65.

FELETAR, Dragutin (2011.), Regionalni park Mura-Drava, Meridijani, 155, Samobor, svibanj 2011., 22-35.

FELETAR, Dragutin (2013.), Fljojsari - nekadašnji dravski mornari, Meridijani, 176, Samobor, 58-65.

FELETAR, Dragutin, PETRIĆ, Hrvoje (2007.), Donja Dubrava - središte splavarstva na rijeci Dravi, Ekonomska i ekohistorija, 3, Zagreb, 156-181.

FELETAR, Dragutin, PETRIĆ, Hrvoje (2007., 2014.), Općina i župa Donja Dubrava, Donja Dubrava, Meridijani.

FELETAR, Dragutin, ur. (2015.), 750 godina grada Preloga, Meridijani, Prelog.

FELETAR, Petar (2005.), Istočno Međimurje, Samobor, Meridijani.

FELETAR, Petar (2015.), Geografsko-prometni položaj kao čimbenik razvoja, 750 godina grada Preloga, Meridijani, Prelog, 19-36.

FELETAR, Petar (2016.), Hrvatske povijesne ceste - Karolina, Jozefina i Lujzijana, Meridijani, Zagreb - Samobor.

FILIĆ, Krešimir (1971.), Brod i kasniji mostovi na Dravi kraj Varaždina, Kajkavski kalendar za 1972., Čakovec.

GAMS, Ivan (1959.), Pohorsko Podravje, Razvoj kulturne pokrajine, SAZU, Ljubljana.

GOLEC, Boris (2005.), Ormož v stoletjih mestne avtonomije. Posestna, demografska, gospodarska, socialna, etnička in jezikovna podoba mesta ob Dravi, 1331.-1849., Založba ZRC SAZU, Ljubljana.

GOLEC, Boris (2018.), Nedovršena kroatizacija dijelova istočne Slovenije od 16. do 19. stoljeća, Meridijani, Zagreb (na slovenskom izdano 2012.).

GOLUB, Siniša, ur. (2003.), Međimurje - zemlja između voda, SPRUD, Čakovec. 
GÖNCZI, Ferencz (1995.), Međimurje - ljudi, vjerovanja, običaji, reprint, Čakovec (original na mađarskom, 1895.).

GRÜNFELDER, Anna Maria (1996.), Drava, Podravski zbornik, 22, Muzej grada, Koprivnica, 37-74.

HACQUET, Balthazar (1784.), Oryctographia Carniolica oder Physikalische Erdbeschreibung des Herzogtums Krain, Istrien, und zum Theil der benachbarten Länder, Leipzig.

HALLER, Jenö (2016., na mađarskom 1912.), Povijest Legrada, Meridijani, Legrad.

HOLJEVAC, Željko (2011.), O mlinovima i mlinarenju na Dravi, potkraj 18. i u 19. stoljeću, Ekonomska i ekohistorija, 7, Zagreb, 111-116.

HORVAT, Anđela (1956.), Spomenici arhitekture i likovnih umjetnosti u Međumurju, Zagreb.

HORVAT, Rudolf (1944.), Poviest Međimurja, Zagreb.

HORVAT, Rudolf (1993.), Povijest grada Varaždina, Zavod za znanstveni rad, HAZU, Varaždin.

HORVAT, Rudolf (1994.), Povijest trgovine, obrta i industrije u Hrvatskoj, AGM, Zagreb.

INGOLIČ, Anton (1937.), Podravski splavarji, Naš rod, 38, Ljubljana.

INGOLIČ, Anton (1937.), S splavarji po Dravi in Donavi, Žika, 9, Ljubljana.

INGOLIČ, Anton (1940.), Na splavih, roman, Založila Modra ptica, Ljubljana.

JEMBRIH, Alojz (2017.), Kotoripski protokol (1724.-1804.), Općina Kotoriba, Kotoriba

JEŽ, Matjaž (1999., Drava nas povezuje, Planinarski zbornik za 1999., Varaždin, 3741.

JUVAN, Ivan (1986.), Plavljenje lesa in splavarjenje po Dravi, Savinji in Savi, Maribor.

KALŠAN, Vladimir (2000.). Građansko društvo u Međimurju, Čakovec.

KALŠAN, Vladimir (2006.), Međimurska povijest, Čakovec.

KALŠAN, Vladimir (2006.), Židovi u Međimurju, katalog, Muzej Međimurja, Čakovec.

KANOP, Maja (2000.), Drava - nekdaj plovna reka, Drva nekoć in danes, Maribor, 155-196.

KARAMAN, Igor (1986.), Privreda i društvo Hrvatske u 19. stoljeću, Školska knjiga, Zagreb.

KELEMEN, Lidija (2015.), Kotoripski protokol (1724.-1768.), Donjomeđimurski zbornik, 2, Meridijani, Prelog, 70-100.

KELEMEN, Lidija (2015.), Kotoripski protokol (1769.-1789., 1803., 1804.), Podravina, 28, Meridijani, Koprivnica, 108-143. 
KELEMEN, Lidija (2017.), Trgovišta Krapina i Kotoriba u 18. stoljeću, Meridijani, Samobor

KLAIĆ, Vjekloslav (1876.), Prirodni zemljopis Hrvatske, Zagreb.

KOLAR, Nataša (1992.), Plovba po Dravi v prvi polovici 19. stoletja, Kronika, 40/3, Maribor.

KOREN, Mirjana (2018.), Začetki industrializacije mizarstva v Mariboru, 2 Kronika, 66, Zveza zgodovinskih društev Slovenije, Ljubljana, 253-263.

KOSI, Miha (1998.), Potujoči srednji vek, Cesta, popotnik in promet na Slovenskem med antiko in 16. stoletjem, Založba ZRC, SAZU Ljubljana.

LESKOSCHEK, Franz (1973.), Die Drauflösser. Zeitschrift des historischen Vereins für Steiermark, 64, Graz.

MACUH, Peter i dr. (2000.), Drava nekoč in danes, Zemljepisne, zgodovinske in etnološke značilnosti sveta ob Dravi; splavarstvo in energetika, Založba Obzorja, Maribor.

MARKOVIĆ, Mirko (1993.), Descriptio Croatiae, Hrvatske zemlje na geografskim kartama od najstarijih vremena do pojave prvih topografskih karata, Naprijed, Zagreb.

MATIJEVIĆ SOKOL, Mirjana (2009.), Povlastica Andrija II. Varaždinu iz 1209. godine, 800 godina slobodnog kraljevskog grada Varaždina, Zavod za znanstveni rad, Varaždin, 19-25

MOHOROVIČIĆ, Andre, ur. (1983.), Varaždinski zbornik, HAZU, Skupština općine, Varaždin.

MRAVLJAK, Josip (1927.), Bratovščina splavarjev v Vuzenici, Časopis za zgodovino in narodopisje, 20, Maribor.

OBADIĆ, Ivan (2007.), Međuodnos ljudi i rijeke na području Varaždinske Podravine u ranom novom vijeku, Radovi Zavoda za znanstveni rad HAZU, Varaždin, 301-326.

OPĆINSKI protokol zebrane občine Donja Dubrava, od 1784. do 1817. godine, Arhiv Međimurja, Štrigova.

OSNOVNA škola Donja Dubrava, album starih fotografija o obiteljima Hirschler i Zalan, te druga dokumentacija.

PAVLIC, Krešimir (2015.), Ispiranje zlata u Međimurju, Matica hrvatska, Čakovec.

PEČAR BANJANOVIČ, Silva (2000.), Zgodbe s pridihom zgodovine, Drava nekoč in danes, Založba Obzorja, Maribor, 267-312.

PEHARNIK, Franjo (1962.), Šajke in splavi na Dravi, Vuhred-Maribor, rukopis.

PETR MARČEC, Smiljana (2004.), Drava i ruralno stanovništvo Međimurja, Život uz Dravu nekad i danas, Gradski muzej, Zavod za znanstveni rad HAZU, Varaždin, 47-52.

PETRIĆ, Hrvoje (1992.), Srednjovjekovni putevi u Podravini, Podravski zbornik, 18, Koprivnica, 41-46. 
PETRIĆ, Hrvoje (2000.), Općina Drnje, Meridijani, Drnje.

PETRIĆ, Hrvoje (2001.), Rijeka Drava od štajersko-hrvatske granice do ušća u Dunav početkom 1780-tih godina, Ekonomska i ekohistorija, 7, Zagreb, 49-83.

PETRIĆ, Hrvoje (2005.), Utjecaj rijeke na pogranična naselja. Primjer rijeke Drave u 18. i 19. stoljeću, Ekonomska i ekohistroija, 1, Zagreb, 37-62.

PETRIĆ, Hrvoje (2011.), Rijeka Drava i međimursko selo u novom vijeku - primjer Donje Dubrave (18.-20. stoljeće), Podravina, 20, Koprivnica, 35-48.

PETRIĆ, Hrvoje, (1993.), Prilog poznavanju srednjovjekovnih puteva u središnjoj Hrvatskoj, Radovi Zavoda za hrvatsku povijest, II./26, Zagreb, 17-26.

PETRIĆ, Hrvoje, FELETAR, Dragutin, FELETAR, Petar (2001.), Novi Zrin - Zrinska utvrda na Muri, Meridijani, Zagreb.

PICKL, Oskar (1988.), Udio Štajerske u pobjedi nad Turcima kod brda Harsany 1687. godine, Prilog logistici Velikog turskog rata, Historijski zbornik, 41, Zagreb, 209-218.

PICKL, Otto (1977.), Mur und Drau als Verkehrswege nach dem Südosten, Razvoj prometnih veza u panonskom prostoru do 1918. godine, Simpozij Modinci 1977., sv. 9, Maribor, 225-240.

PROTOCULUM novum Oppidi Kotoriba Inchoarum Anno Domini milesimo septingentisimo vigesimo quatro, Protokol trgovišta Kotoriba, 1724.-1804., Arhiv HAZU, IV.b.35, Zagreb.

PUFF, Rudolf Gustav (1999.), Maribor, Založba Obzorja, Maribor.

RADOVANOVIČ, Sašo (2004.), Podravje, Kapital, Maribor.

ROKSANDIĆ, Drago (2011.), Drava očima Jozefinista, Ekonomska i ekohistorija, 7, Zagreb, 18-37.

SLUKAN ALTIĆ, Mirela (2003.), Podravsko srednjovjekovlje u zrcalu kartografskih izvora, Podravina, 4, Koprivnica, 121-132.

SOMEK, Petra, FELETAR, Dragutin (2015.), Pregled graditeljske baštine na području grada Preloga, 750 godina grada Preloga, Meridijani, Prelog, 423-524.

SPLAVARSKI muzej Šarman u Javniku, občina Podvelka (Ožbalt), dokumentacija i etnografski materijal (konzultirano 2015.).

SPOMENICA župe Sv. Margarete u Donjoj Dubravi (Liber memorabilium ecclesiae S. Margarethi), Župni ured Donja Dubrava.

ŠAFAR, Dragutin (1991.), Donja Dubrava između dva rata, Čakovec.

ŠAFAR, Dragutin (1998.), Dubravska restauracija Rusak nekoć, Dobravske novine, Donja Dubrava, 24. prosinca 1998.

ŠAFAR, Dragutin (2008.), „Dolnja rajža“ - Vukovar, Bata, Dobravske novine, Donja Dubrava, 25. prosinca 2008.

ŠAFAR, Dragutin (2008..), O nekadašnjem židovskom stanovništvu Donje Dubrave, Dobravske novine, Donja Dubrava, 13. srpnja 2008. 
ŠAFAR, Dragutin (2012.), Dobravsko plemstvo 18. i 19. stoljeća, Dobravske novine, 38, Donja Dubrava, 13. 7. 2012.

ŠICEL, Miroslav, KAŠTELA, Slobodan, ur. (2009.), 800 godina slobodnog kraljevskog grada Varaždina, 1209.-2009., Zavod za znanstveni rad HAZU, Varaždin.

ŠIMEK, Marina (2004.), Naseljavanje u prapovijesti i ranoj povijesti, Život uz Dravu nekad i danas, Gradski muzej, Zavod za znanstveni rad HAZU, Varaždin, 2334.

ŠMON, Marijan (2000.), Drava, vir električne energije, Drava nekoč in danes, Založba Obzorja, Maribor, 370-425.

ŠTUMBERGER, Barbara, ur. (2013.), Obrt na Ptujskem, Zbornik ob 40-letnici OOZ Ptuj, Ptuj.

TANODI, Zlatko (1942.), Poviestni spomenici slobodnog i kraljevskog grada Varaždina, Gradski muzej, Varaždin.

TAUBE, Fridrich Wilhelm von (1777., 1778.), Historische und geographische Beschreibung des Königreiches Slavonien und die Herzogthumes Sirmien, sovohl nach ihrer natürlichen Beschaftenheit, als auch ihrer issigen Verfassung und neuen Einrichtung in kirchlichen, bürgerlichen und militärischen Dingen, Bücher I., II., III., Leipzig.

TEŽAK, Spomenka (2004.), Varaždinci i rijeka Drava, Život uz Dravu nekad i danas, Gradski muzej, Zavod za znanstveni rad HAZU, Varaždin, 35-46.

TOMA, Dragutin (1972.), Cehovi u Međimurju, Zbornik Pedagoške akademije, I., Čakovec, 79-90.

UJLAKI, Slaven (2016.), Donjodubravski plemenitaši - obitelj Hirschler/Zalan, Donjomeđimurski zbornik, 3, Meridijani, Prelog, 104-113.

VALVASOR, Janez Vajkard (Walvasor, Jochan Weickard) 2009.-2014. (1689.), Čast in slava vojvodine Kranjske (Die Ehre des Herzogthums Crain), Zavod Dežela Kranjska, Ljubljana (Laibach - Nürnberg), I.-V.

VÁNDOR, László, VARGA, András, (1997.), Zala megye ezer éve, Zala Megye Önkormányzata, Zalaegerszeg.

VERBOTEN, Ivan, MACUH, Peter (2000.), Splavarstvo na Dravi in Donavi, Drava nekoć in danes, Maribor, 197-258.

VUK, Vili (1996.), Dravski splavarji od Ptuja do Borla, Ptujski zbornik, VI./2, Ptuja, $11-28$.

ZELKO, Ivan (1996.), Zgodovina Prekmurja, Pomurska založba, Murska Sobota.

ZORN, Matija (2018.), Gospodarska vloga reke Drave v Sloveniji - od plovnosti reke do hidroenergetske izrabe, Podarvina, 33, Meridijani, Koprivnica, 51-62.

ZWITTER, Žiga (2014.), Agrarna zgodovina podložnikov dveh gospostev med Podjuno in Menino v 16. in 17. stoletju, Vizija raziskav slovenske gospodarske in družbene zgodovine, Zgodovinski inštitut Milka Kosa, SAZU, Ljubljana. 
ŽIBERNA, Igor (2000.), Geografski oris slovenskoga Podravja, Drava nekoč in danes, Založba Obzorja, Maribor, 19-61.

ŽIVAKOVIĆ KERŽE, Zlata (2002.), Drava kao os života, razvoja i odnosa kroz povijest, Poseban osvrt na donji tok rijeke, Anali Zavoda za znanstveni i umjetnički rad HAZU, Osijek, 41-69. 


\section{Summary}

\section{Tributes to the History of Log Floating on the River Drava} in the 19th and the 20th Centuries

Drava, one of Croatia's greatest rivers, played a major role for the life of the population in the past. One of the major life functions of the river Drava was the traffic. It was this river that represented the jugular vein connecting the population living alongside the whole basin. One of the most important components of the traffic function was log floating. In the introductory part, the paper tackles the conditions for traffic on the river Drava; following, the history of log floating from the Antiquity to the mid-20th century is presented. Special attention has been paid to the development of log floating on Drava in the period from the end of the 18th century to the mid-20th century, and thorough analysis of the traffic in Slovenian ports from Dravograd to Duplek, and business-distribution ports from Maribor to Đerdap, has been conducted. The paper offers a detailed analysis of the operation of the company UjlakiHirschler i sin in Donja Dubrava, which was the centre of log floating on Drava in the 19th and the 20th centuries. A study has been made of log building and the features thereof, as well as of the life and work of log floaters.

Keywords: log floating; port (landing place); Drava; log floaters' guild; Donja Dubrava. 